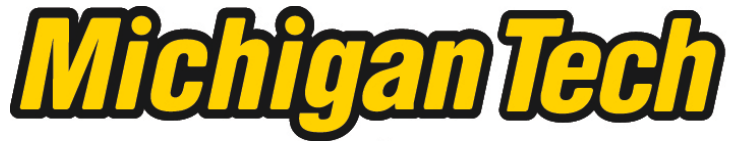 \\ Michigan Technological University Create the Future Digital Commons @ Michigan Tech
}

Dissertations, Master's Theses and Master's Reports - Open

Dissertations, Master's Theses and Master's

Reports

2014

DENITRIFICATION IN SOILS: FROM GENES TO ENVIRONMENTAL OUTCOMES

Jianqiu Zheng

Michigan Technological University

Follow this and additional works at: https://digitalcommons.mtu.edu/etds

Part of the Biogeochemistry Commons, Biology Commons, and the Environmental Sciences Commons

Copyright 2014 Jianqiu Zheng

\section{Recommended Citation}

Zheng, Jianqiu, "DENITRIFICATION IN SOILS: FROM GENES TO ENVIRONMENTAL OUTCOMES",

Dissertation, Michigan Technological University, 2014.

https://doi.org/10.37099/mtu.dc.etds/948

Follow this and additional works at: https://digitalcommons.mtu.edu/etds

Part of the Biogeochemistry Commons, Biology Commons, and the Environmental Sciences Commons 


\title{
DENITRIFICATION IN SOILS: FROM GENES TO ENVIRONMENTAL OUTCOMES
}

\author{
By \\ Jianqiu Zheng

\begin{abstract}
A DISSERTATION
Submitted in partial fulfillment of the requirements for the degree of DOCTOR OF PHILOSOPHY

In Atmospheric Sciences
\end{abstract}

MICHIGAN TECHNOLOGICAL UNIVERSITY

2014

(C)2014 Jianqiu Zheng 
This dissertation has been approved in partial fulfillment of the requirements for the Degree of DOCTOR OF PHILOSOPHY in Atmospheric Sciences.

Department of Civil and Environmental Engineering

\author{
Dissertation Advisor: $\quad$ Paul V. Doskey \\ Committee Member: Erik Lilleskov \\ Committee Member: Jennifer G. Becker \\ Committee Member: Evan S. Kane
}

Department Chair: $\quad$ David Hand 
Dedication

To my family, on the other side of the Pacific... 


\section{CONTENTS}

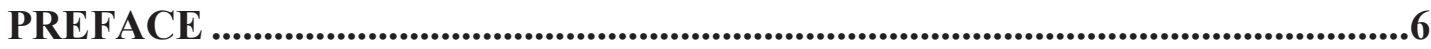

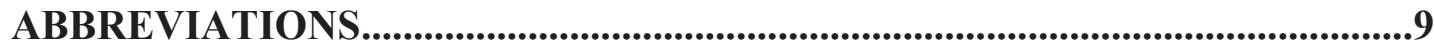

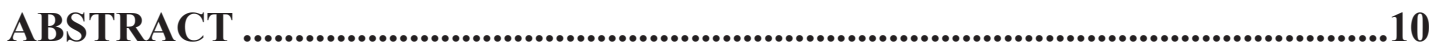

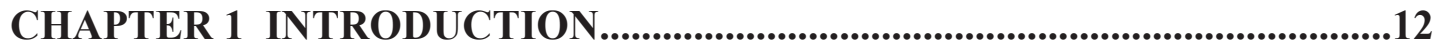

ENZYMES IN BACTERIAL DENITRIFICATION ......................................13

CELLULAR LEVEL REGULATION ON DENITRIFICATION ................17

MICROBIAL KINETICS OF DENITRIFICATION ....................................19

DENITRIFICATION IN BIOGEOCHEMICAL MODELS.........................21

CHAPTER 2 MODELING NITROUS OXIDE PRODUCTION AND REDUCTION IN SOIL THROUGH EXPLICIT REPRESENTATION OF DENITRIFICATION ENZYME KINETICS ....................................................30

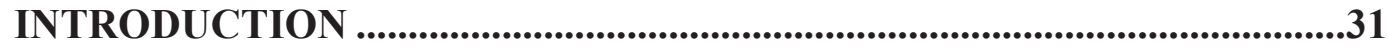

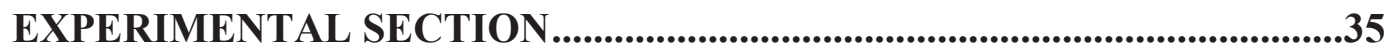

RESULTS .......................................................................................................................441

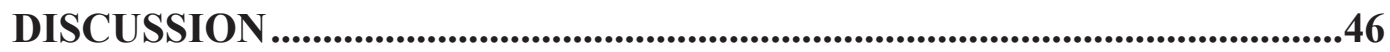

CHAPTER 3 DYNAMICS OF NITROUS OXIDE IN SOIL GAS AND SURFACE FLUXES FOLLOWING SIMULATION OF SEQUENTIAL PRECIPITATION EVENTS .....................................................................................80

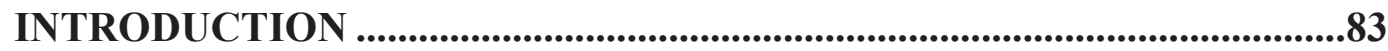

MATERIALS AND METHODS ..................................................................86

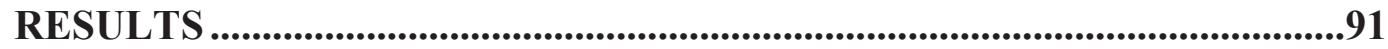




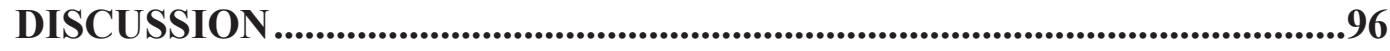

ACKNOWLEDGEMENTS .........................................................................101

CHAPTER 4 DELAYED SYNTHESIS OF N 2 OR EXPLAINS DYNAMICS OF $\mathrm{N}_{2} \mathrm{O}$ IN AGRICULTURAL SOIL FOLLOWING RAINFALL ..........................121

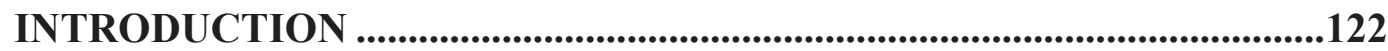

DYNAMICS OF $\mathrm{N}_{2} \mathrm{O}$ FOLLOWING RAINFALL ........................................123

MODELING OF $\mathrm{N}_{2} \mathrm{O}$ PRODUCTION AND REDUCTION ...........................125

BIOTIC AND ABIOTIC CONTROLS ON DENITRIFICATION ................128

METHODS .............................................................................................................131

CHAPTER 5 CONCLUSIONS AND PERSPECTIVES ......................................153

APPENDIX A WEATHER DATA FILE FOR BIOGEOCHEMICAL

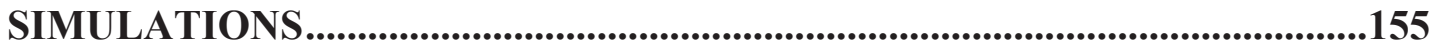




\section{Preface}

Ch 2. Zheng J, Doskey, P. Modeling nitrous oxide production and reduction in soil through explicit representation of denitrification enzyme kinetics. Manuscript submitted to Environmental Science \& Technology.

Ch 3. Zheng J, Doskey, P. Dynamics of nitrous oxide in soil gas and surface fluxes following simulation of sequential precipitation events. Manuscript submitted to Global Change Biology.

Ch 4. Zheng J, Doskey, P. Delayed synthesis of $\mathrm{N}_{2} \mathrm{OR}$ explains dynamics of $\mathrm{N}_{2} \mathrm{O}$ in agricultural soil following rainfall. Manuscript submitted to Nature Geosciences.

The contribution of the authors to the manuscripts included in this thesis was as follow:

Ch 2. Jianqiu Zheng performed data collection, model development, and writing of the manuscript. Paul Doskey edited the manuscript before final submission.

Ch 3. Jianqiu Zheng performed data collection, model development, and writing of the manuscript. Paul Doskey edited the manuscript before final submission.

Ch 4. Jianqiu Zheng performed data collection, analysis, and writing of the manuscript. Paul Doskey edited the manuscript before final submission. 


\section{Acknowledgements}

This thesis represents not only my work at the keyboard, it is also a milestone in my life. It summaries a wonderful journey in which I explore and learn, grow and develop. The best and worst moments of this journey have been shared with many people, who made it colorful and unforgettable.

This thesis would not have been possible without the inspiration and support of a number of wonderful individuals. I owe my deepest gratitude to my mentor Professor Paul Doskey, who has supported me academically and emotionally through the rough road to obtain a $\mathrm{PhD}$. His enthusiasm and patience have made a deep impression on me. He guides me with knowledge, encouragement and freedom, and gives me a meaningful direction for my career in science.

I also want to express my warmest gratitude to my thesis committee for guiding me through all these years, Professor Erik Lilleskov, Jennifer Becker, Tom Pypker -Not only for their time and extreme patience, but for their intellectual inputs to the development and proceeding of my thesis project. I am particularly appreciative to Professor Evan Kane, for agreeing to serve on the thesis committee on short notice. To David Perram, for sharing his decades of wisdom in the lab. To Professor Alex Mayer and professor Eric Seagren, for their inspiring advice that helped me solving various problems during the thesis preparation. To Professor Joseph von Fischer, for the interesting and inspiring conversation at Max Planck. 
I am deeply thankful to my dearest friends Carley Kratz and Raquel Taveras for being wonderful friends, continuing source of encouragement and inspiration.

Finally, my deep and sincere gratitude to my family for their continuous and unparalleled love, help and support. They selflessly encouraged me to explore new directions in life and seek my own destiny. This journey would not have been possible if not for them, and I dedicate this thesis to them. 


\section{Abbreviations}

$\begin{array}{ll}\text { EOC } & \text { Extractable soil organic carbon } \\ \mathrm{N}_{2} & \text { Dinitrogen gas } \\ \mathrm{N}_{2} \mathrm{O} & \text { Nitrous oxide } \\ \mathrm{N}_{2} \mathrm{OR} & \text { Nitrous oxide reductase } \\ \mathrm{NAR} & \text { Nitrate reductase } \\ \mathrm{NIR} & \text { Nitrite reductase } \\ \text { nirK } & \text { Gene encoding copper nitrite reductase } \\ n i r \mathrm{~S} & \text { Gene encoding cytochrome } c d_{1} \text { nitrite reductase } \\ \mathrm{NO}^{-} & \text {Nitric oxide } \\ \mathrm{NO}_{2}{ }^{-} & \text {Nitrite } \\ \mathrm{NO}_{3}{ }^{-} & \text {Nitrate } \\ \mathrm{NOR}^{-} & \text {Nitric oxide reductase } \\ n o s \mathrm{Z} & \text { Gene encoding nitrous oxide reductase } \\ \text { PLFA } & \text { Phospholipid fatty acid } \\ \text { WFPS } & \text { Water-filled pore space }\end{array}$




\begin{abstract}
Denitrification is an important process of global nitrogen cycle as it removes reactive nitrogen from the biosphere, and acts as the primary source of nitrous oxide $\left(\mathrm{N}_{2} \mathrm{O}\right)$. This thesis seeks to gain better understanding of the biogeochemistry of denitrification by investigating the process from four different aspects: genetic basis, enzymatic kinetics, environmental interactions, and environmental consequences. Laboratory and field experiments were combined with modeling efforts to unravel the complexity of denitrification process under microbiological and environmental controls.
\end{abstract}

Dynamics of denitrification products observed in laboratory experiments revealed an important role of constitutive denitrification enzymes, whose presence were further confirmed with quantitative analysis of functional genes encoding nitrite reductase and nitrous oxide reductase. A metabolic model of denitrification developed with explicit denitrification enzyme kinetics and representation of constitutive enzymes successfully reproduced the dynamics of $\mathrm{N}_{2} \mathrm{O}$ and $\mathrm{N}_{2}$ accumulation observed in the incubation experiments, revealing important regulatory effect of denitrification enzyme kinetics on the accumulation of denitrification products. Field studies demonstrated complex interaction of belowground $\mathrm{N}_{2} \mathrm{O}$ production, consumption and transport, resulting in two pulse pattern in the surface flux. Coupled soil gas diffusion/denitrification model showed great potential in simulating the dynamics of $\mathrm{N}_{2} \mathrm{O}$ below ground, with explicit representation of the activity of constitutive denitrification enzymes. A complete survey of environmental 
variables showed distinct regulation regimes on the denitrification activity from constitutive enzymes and new synthesized enzymes. Uncertainties in $\mathrm{N}_{2} \mathrm{O}$ estimation with current biogeochemical models may be reduced as accurate simulation of the dynamics of $\mathrm{N}_{2} \mathrm{O}$ in soil and surface fluxes is possible with a coupled diffusion/denitrification model that includes explicit representation of denitrification enzyme kinetics.

In conclusion, denitrification is a complex ecological function regulated at cellular level. To assess the environmental consequences of denitrification and develop useful tools to mitigate $\mathrm{N}_{2} \mathrm{O}$ emissions require a comprehensive understanding of the regulatory network of denitrification with respect to microbial physiology and environmental interactions. 


\section{Chapter 1 Introduction}

Denitrification is the reduction of nitrogen oxides, which enables microbes to maintain respiratory metabolism when oxygen is limited. During denitrification process, nitrogen oxides are used as electron acceptors by an electron transport chain similar to that used in aerobic respiration (Zumft, 1997). The complete denitrification comprises four steps, in which nitrate $\left(\mathrm{NO}_{3}^{-}\right)$is converted, via nitrite $\left(\mathrm{NO}_{2}{ }^{-}\right)$, to nitric oxide $(\mathrm{NO})$ and nitrous oxide $\left(\mathrm{N}_{2} \mathrm{O}\right)$, and then to the inert gas dinitrogen $\left(\mathrm{N}_{2}\right)$. Four enzymes are required sequentially to reduce $\mathrm{NO}_{3}{ }^{-}$to $\mathrm{N}_{2}$, including nitrate reductase (NAR), nitrite reductase (NIR), nitric oxide reductase (NOR), and nitrous oxide reductase $\left(\mathrm{N}_{2} \mathrm{OR}\right)$, acting as a module that allows accumulation of intermediate products during denitrification.

Microbial denitrification is the dominant source of atmospheric $\mathrm{N}_{2} \mathrm{O}$, which is not only a long-lived greenhouse gas, but also contributes to stratospheric ozone depletion (Ravishankara et al., 2009). Recent measurements from Antarctic ice core suggest that the atmospheric mixing ratio of $\mathrm{N}_{2} \mathrm{O}$ has increased by $21 \%$ during the last 200 years (MacFarling Meure et al., 2006), and this trend is likely to continue in the coming decades due to soil emissions. The IPCC AR5 estimated that current natural sources of $\mathrm{N}_{2} \mathrm{O}$ is about $11 \mathrm{Tg} \mathrm{N} \mathrm{N}_{2} \mathrm{O}-\mathrm{N} \mathrm{yr}^{-1}$, with soils under natural vegetation contributing about $60 \%$ (Ciais et al., 2013). Agricultural soil emission owing to the application of $\mathrm{N}$ fertilizers has been estimated at $4.2 \mathrm{Tg} \mathrm{N}_{2} \mathrm{O}-\mathrm{N} \mathrm{yr}{ }^{-1}$, accounting for $66 \%$ of global anthropogenic emissions. Modeling studies project an annual emission 
of $9.0 \mathrm{Tg} \mathrm{yr}^{-1}$ from agricultural soils in 2050 (Bouwman et al., 2013). Although considerable improvement in our understanding on soil $\mathrm{N}_{2} \mathrm{O}$ emissions has been made over the past decades, effective mitigation for $\mathrm{N}_{2} \mathrm{O}$ emissions remains a research frontier and challenge.

Emissions of $\mathrm{N}_{2} \mathrm{O}$ from soil are episodic and primarily occur as short pulses following fertilization and precipitation events (Barton et al., 2008, Nobre et al., 2001, Parkin \& Kaspar, 2006). Large proportion ( $>65 \%)$ of annual $\mathrm{N}_{2} \mathrm{O}$ emissions occurs over time scales of hours to weeks in response to management practices and climate events (Venterea et al., 2012). Although we identified important environmental factors controlling denitrification activity, i.e., oxygen, nitrate and available carbon, it is still difficult to quantify and model the hotspots and hot moments in $\mathrm{N}_{2} \mathrm{O}$ emissions. As a microbial mediated process, denitrification is controlled by both the soil physical conditions, and the denitrifying community in soils. Soil environments strongly affect the distribution and diversity of denitrifying community, and also the spatial and temporal location of denitrification. Thus, it is important to understand that a complex and interactive number of factors are involved in the regulatory network of denitrification and subsequent $\mathrm{N}_{2} \mathrm{O}$ emissions. In particular, it is critical to understand the factors that regulate the synthesis and activation of denitrification proteome and drive the wider ecology of the microorganisms involved.

\section{ENZYMES IN BACTERIAL DENITRIFICATION}


Denitrification requires four reductases to sequentially reduce $\mathrm{NO}_{3}{ }^{-}$to $\mathrm{N}_{2}$. The structures of denitrification enzymes (i.e., NAR, NIR, NOR, and $\mathrm{N}_{2} \mathrm{OR}$ ) have been characterized during the past decade or so (Einsle et al., 1999, Hino et al., 2010, Matsumoto et al., 2012, Moreno-Vivian et al., 1999, Murphy et al., 1997, Pomowski et al., 2011, Richardson et al., 2001, Sato et al., 2014, Shiro, 2012). These include two dissimilatory nitrate reductase, two types of nitrite reductase, two types of nitrite reductase, and a $\mathrm{N}_{2} \mathrm{OR}$ with copper-sulfur cluster.

Two types of dissimilatory nitrate reductases are present in bacteria: the membrane-bound NAR, and the periplasmic NAP. Membrane-bound NAR contains a catalytic subunit with molybdenum cofactor, an electron transfer subunit with four iron-sulfur centers, and a membrane biheme $b$ quional-oxidizing subunit (MorenoVivian et al., 1999). NAR proteins are synthesized during anaerobic growth, via $\mathrm{O}_{2}-$ sensitive DNA-binding protein FNR (fumarate nitrate reduction regulatory protein) that senses the environmental $\mathrm{O}_{2}$ tension using an iron-sulfur cluster. The periplasmic NAP system also involves molybdenum cofactor and iron-sulfur center binding. However, NAP system does not response to $\mathrm{O}_{2}$ inhibition, and it may be critical for denitrifiers preforming aerobic denitrification (Moreno-Vivian et al., 1999).

The reduction of $\mathrm{NO}_{2}{ }^{-}$to $\mathrm{NO}$ is catalyzed by two completely different types of nitrite reductase: cytochrome $c d_{l}$ (encoded by nirS) and Copper-containing nitrite reductase (encoded by $n i r K)$ (Zumft, 1997). Cytochrome $c d_{1}$ nitrite reductase is a 
homodimer and each domain contains one heme $c$ and one heme $d_{l}$. A heme iron nitrosyl intermediate $\left(\mathrm{Fe}^{+}-\mathrm{NO}^{+}\right)$is proposed in the mechanism for $\mathrm{NO}$ production (Murphy et al., 1997). Nitrite binds to the ferrous heme $d_{1}$ to form NO and displace this reaction product from the ferric heme. Copper-containing nitrite reductases are trimer proteins composed of three identical subunits. Each monomer contains two copper ions, type I and type II copper site. Type I copper site transfers an electron from the redox-partner protein to the catalytic type II copper site, where $\mathrm{NO}_{2}^{-}$is bound and reduced to NO (Nojiri et al., 2009).

Nitric oxide is an intermediate product in the denitrification process, however, due to its cyto-toxicity, it is usually scavenged by NOR immediately after its production. The molecular structure of NOR is solved very recently, and two distinct types of bacteria NORs were reported: cytochrome c-dependent NOR (cNOR) from a Gram-negative bacteria, and quinol-dependent NOR (qNOR) from a Gram-positive bacteria (Hino et al., 2010, Matsumoto et al., 2012). Among the two types of NORs, cNOR is more extensively studied. cNOR is a membrane-integrated iron-containing enzyme consisting two subunits, NorB and NorC. NorB subunit contains heme $b$ and a binuclear catalytic center that consists of heme $b_{3}$ and one non-heme iron $\mathrm{Fe}_{\mathrm{B}}$ (Hino et al., 2010). The binuclear center binds and activates two NO molecules forming the $\mathrm{N}-\mathrm{N}$ bond of $\mathrm{N}_{2} \mathrm{O}$. To accommodate two $\mathrm{NO}$ molecules, further conformational changes at the binuclear center is required to position two NO molecules to form N-N bond (Shiro, 2012). 
Nitrous oxide is a kinetically inert gas, and the only known enzyme that capable of reducing $\mathrm{N}_{2} \mathrm{O}$ to $\mathrm{N}_{2}$ is the respiratory $\mathrm{N}_{2} \mathrm{O}$ reductase $\left(\mathrm{N}_{2} \mathrm{OR}\right)$. $\mathrm{N}_{2} \mathrm{OR}$ is a copperdependent enzyme located in the bacteria periplasm. Recently structural evidence reveals that $\mathrm{N}_{2} \mathrm{O}$ binds side-on at a [4Cu:2S] copper sulfur cluster $(\mathrm{Cuz})$, in close proximity to the other multi-copper center $\mathrm{Cu}_{\mathrm{A}}$ in $\mathrm{N}_{2} \mathrm{OR}$ (Pomowski et al., 2011). Electron from cytochrome $c$ is transferred to the catalytic center $\mathrm{Cu}_{\mathrm{Z}}$ via $\mathrm{Cu}_{\mathrm{A}}$, and the reduction takes place in a hydrophilic, distal chamber, allowing the product $\mathrm{N}_{2}$ exits $\mathrm{Cu}_{\mathrm{z}}$ center via a hydrophobic channel to the protein surface. The structural data also demonstrates a redox-inactive form of $\mathrm{Cu}$, which contains only one sulfide ion, [4Cu:S]. The formation of [4Cu:S] is possibly due to the removal of the bridging sulfur by diffused $\mathrm{O}_{2}$ (Pomowski et al., 2011).

The structural and functional characterization of denitrification enzymes demonstrated their high dependency on metal cofactors. The four denitrification enzymes obtain electrons from a common source, branched quinol/cytochrome $c$ pool, moving protons from the cytoplasm to the periplasm (Richardson et al., 2009). This protonmotive force drives the synthesis of ATP, thus the denitrification pathway is similar to the oxygen respiratory system. Denitrification is primarily an anaerobic process, and sensors for effecting the change from $\mathrm{O}_{2}$ respiration to denitrification are key regulators on the synthesis and activation of denitrification enzymes. $\mathrm{O}_{2}$-sensitive DNA-binding proteins found in the regulatory network of denitrification include FNR (fumarate nitrate reduction regulatory protein), that measures the level of $\mathrm{O}_{2}$ using an iron-sulfur cluster, as well homologues of this 
protein, NNR (nitrite and nitric oxide reduction regulatory protein) (Bergaust et al., 2012, Mazoch et al., 2003). The NAR, NIR and NOR are generally tolerant of $\mathrm{O}_{2}$, as both NOR and the iron-containing cytochrome $c d_{l}$ NIR can catalyze the fourelectron reduction of $\mathrm{O}_{2}$ to water (Richardson et al., 2009). On the other hand, the catalytic site in $\mathrm{N}_{2} \mathrm{OR}$ can be irreversibly damaged during transient exposure to $\mathrm{O}_{2}$.

\section{CELLULAR LEVEL REGULATION ON DENITRIFICATION}

The accumulation of denitrification intermediates is controlled by the enzymatic rates (Betlach \& Tiedje, 1981), which is determined by the cellular abundance and activity of denitrification enzymes. Studies demonstrate that enzyme abundance and activity are governed by abiotic factors inhibiting one or more enzymes (Bateman \& Baggs, 2005), differential transcription of functional genes encoding the enzymes (Bakken et al., 2012), or absence of functional genes within genome (Jones et al., 2014).

Denitrification is energetically unfavorable comparing with aerobic respiration, but a minimum expression of denitrification enzymes may be necessary for survival during rapid transition from aerobic to anaerobic conditions. Expression of NAR, NIR, and NOR under micro-aerobic or aerobic conditions is a common phenomenon among denitrifiers from the environment (Ka et al., 1997, Lloyd et al., 1987), and is generally understood as a protective mechanism against cytotoxic concentrations of nitrite and nitric oxide (Knowles, 1982). Persisted NAR, NIR, and NOR under micro-aerobic conditions was reported at both enzyme level and gene transcriptional 
level (Dendooven \& Anderson, 1994, Mazoch et al., 2003). However, persistence of $\mathrm{N}_{2} \mathrm{OR}$ was reported to be low under aerated conditions (Dendooven \& Anderson, 1994), mainly due to its fragility to $\mathrm{O}_{2}$ exposure at the catalytic center.

De novo synthesis of denitrification enzymes was likely to follow a sequential order: NAR was formed within 2-3 h, NIR between 4-12 h, and $\mathrm{N}_{2} \mathrm{OR}$ between 24 and $42 \mathrm{~h}$ after anaerobiosis was imposed (Dendooven \& Anderson, 1995). Transcriptional analysis on cultured Pseudomonas fluorescens C7R12 during transit from aerobic to anaerobic conditions showed sequential induction of the denitrification enzymes (Philippot et al., 2001). However, expressions of denitrification enzymes are not always regulated coordinately. For instance, soil bacterium Agrobacterium tumefacien was unable to express NIR and NOR in a balanced way, leading to extremely high emissions of NO. In contrast to $A$. tumefacien, studies on Pseudomonas denitrifican showed that $\mathrm{N}_{2} \mathrm{OR}$ was expressed much earlier than NIR and NOR (and possibly NAR as well), resulting in only trace amount of $\mathrm{N}_{2} \mathrm{O}$ emissions (Bakken et al., 2012). Several denitrifying bacteria were even reported lack of nos $\mathrm{Z}$ (coding for $\mathrm{N}_{2} \mathrm{OR}$ ) gene on their complete genome (Jones et al., 2014), resulting in obvious high $\mathrm{N}_{2} \mathrm{O}: \mathrm{N}_{2}$ ratios of denitrification.

In general, nosZ (encoding $\mathrm{N}_{2} \mathrm{OR}$ ) expression appears to lag behind expression of the genes for the other redutases, when bacteria are going through transition from aerobic to anaerobic conditions, resulting in transient accumulation of $\mathrm{N}_{2} \mathrm{O}$ (Dendooven \& Anderson, 1994, Dendooven \& Anderson, 1995, Firestone \& 
Tiedje, 1979, Holtan-Hartwig et al., 2000, Philippot et al., 2001). The recurring observation suggests a common regulatory pattern in denitrifying communities, which could be ascribed to enzyme kinetics either alone, or together with sequential gene expression. Relative $\mathrm{N}_{2} \mathrm{OR}$ activity (compared to that of the other reductase) is the intracellular control on the transient accumulation of $\mathrm{N}_{2} \mathrm{O}$ and delayed production of $\mathrm{N}_{2}$. As the only known enzyme that acts as biological sink of $\mathrm{N}_{2} \mathrm{O}, \mathrm{N}_{2} \mathrm{OR}$ is the key controlling factor on $\mathrm{N}_{2} \mathrm{O}: \mathrm{N}_{2}$ ratios from denitrification, which may provide possible intervention in the increasing soil $\mathrm{N}_{2} \mathrm{O}$ emissions.

Although a regulator pattern of denitrification enzymes has been revealed with various observations, it is still difficult to generalize the product stoichiometry with selected denitrifying strains regarding their enzymatic kinetics and propensity of emitting $\mathrm{N}_{2} \mathrm{O}$, as the converting efficiency is an 'intrinsic' propensity for different denitrification phenotypes, or even different strains (Bakken et al., 2012, Cavigelli \& Robertson, 2001, Cheneby et al., 2004). Accumulation of intermediates can arise due to either abiotic factors inhibiting one or more enzymes, differential transcription of functional genes, or can be genomic. There's still a need for physiological experiments to characterize the key parameters in enzyme kinetics.

\section{MICROBIAL KINETICS OF DENITRIFICATION}

The kinetics of denitrification has been explicitly modeled with emphasis on the transient accumulation of $\mathrm{N}_{2} \mathrm{O}$. A simple model initiated by Betlach and Teidje demonstrated a Michaelis-Menten type kinetics control on the accumulation of 
nitrogen oxides (Betlach \& Tiedje, 1981). The delayed $\mathrm{N}_{2} \mathrm{O}$ reduction was interpreted by low affinity for $\mathrm{N}_{2} \mathrm{O}$ in the kinetic expression (Dendooven et al., 1994). An updated kinetics model incorporated competitions for electrons between alternative reductase through a double substrate Michaelis-Menten kinetics (Almeida et al., 1997, Thomsen et al., 1994). This frame structure still underlies most kinetic models of denitrification. A recent model decoupled carbon oxidation and nitrogen oxide reduction by introducing reduced and oxidized electron carriers in the Michaelis-Menten kinetic expression (Pan et al., 2013), and different affinity constants were proposed to demonstrate election competitions. These models successfully simulated transient accumulation of $\mathrm{N}_{2} \mathrm{O}$ and could be used for predictive purposes. However, their predictive power is very questionable at finer temporal and spatial resolution, considering that a true representation of the explicit drivers for denitrification, denitrification enzyme dynamics, is missing. A novel metabolic model of denitrification developed with A. tumefaciens (lacked nos Z gene) incorporated enzyme dynamics using transcripts as a proxy of active enzymes, and successfully explained the sequential accumulation of $\mathrm{NO}$ and $\mathrm{N}_{2} \mathrm{O}$ (Kampschreur et al., 2012).

Current advances in molecular biology reveal many functional genes and elements of regulatory networks for denitrification. Induction of denitrification pathway is regulated by multiple promoters for gene expression. The transcriptional regulators and ancillary factors for the transcription of genes coding for the individual reductases reported includes oxygen, nitrite, and NO (Bergaust et al., 
2012, Mazoch et al., 2003). Detailed study characterizing the overall response from combined individual transcriptional regulations has demonstrated that unbalanced expression of denitrification genes is responsible for the different reduction rates between neighboring reactions (Bergaust et al., 2008). With our increasing understanding of the regulatory metabolism of denitrification, the enzyme dynamics can be lumped to transcriptional level regulations (Kampschreur et al., 2012), which might be further applied in kinetic models for better representation of the real-time status of the denitrification enzymes. Kampschreur's pioneer work is a good demonstration for such application in advancing our understanding of the regulation of denitrification process.

\section{DENITRIFICATION IN BIOGEOCHEMICAL MODELS}

Biogeochemical models are mostly designed to simulate $\mathrm{C}$ and $\mathrm{N}$ transformations in the ecosystem. Simplification is necessary for the purpose of ecological modeling, thus empirical relationships between $\mathrm{N}_{2} \mathrm{O}$ and $\mathrm{N}_{2}$ production from denitrification, and environmental variables are widely used. Biogeochemical models have been mostly tested on their ability to reflect the order of magnitude of major $\mathrm{N}_{2} \mathrm{O}$ peaks rather than on their capacity to reproduce correct emission kinetics. Modeling on the temporal variations in surface $\mathrm{N}_{2} \mathrm{O}$ fluxes is still quite challenging due to the lack of physiological basis of denitrification. Simplified representation of denitrifying communities based on relatively antique parameters for enzyme and growth kinetics 
is limiting the predictive power of current biogeochemical models. It seems likely that the current biogeochemical models could be improved with implementation of explicit microbial kinetics.

One of the major difficulties in the application of microbial kinetics of denitrification into biogeochemical models is the lack of direct observations in the field. The regulatory network of denitrification is still mainly limited to laboratory studies of microorganism and soils under controlled conditions. Lacking of process level understanding of $\mathrm{N}_{2} \mathrm{O}$ production and consumption in the field is one of the major limitations in the effort to locate the "hot spots" of the very dynamic $\mathrm{N}_{2} \mathrm{O}$ production within the soil (Butterbach-Bahl et al., 2013). In this thesis, a comprehensive study of the mechanisms involved in the response of soil microbial processes following precipitations with synergistic experimental and modeling approaches was conducted to advance our understanding of the biological and physical regulations of $\mathrm{N}_{2} \mathrm{O}$ emission, and improve our assessment of $\mathrm{N}_{2} \mathrm{O}$ inventories under future climate change scenarios.

\section{References}

Almeida JS, Reis MaM, Carrondo MJT (1997) A Unifying Kinetic Model of Denitrification. Journal of Theoretical Biology, 186, 241-249. 
Bakken LR, Bergaust L, Liu B, Frostegard A (2012) Regulation of denitrification at the cellular level: a clue to the understanding of $\mathrm{N}_{2} \mathrm{O}$ emissions from soils. Philosophical Transactions of the Royal Society of London Series B: Biological Sciences, 367, 1226-1234.

Barton L, Kiese R, Gatter D, Butterbach-Bahl K, Buck R, Hinz C, Murphy DV (2008) Nitrous oxide emissions from a cropped soil in a semi-arid climate. Global Change Biology, 14, 177-192.

Bateman EJ, Baggs EM (2005) Contributions of nitrification and denitrification to $\mathrm{N}_{2} \mathrm{O}$ emissions from soils at different water-filled pore space. Biology and Fertility of Soils, 41, 379-388.

Bergaust L, Shapleigh J, Frostegard A, Bakken L (2008) Transcription and activities of $\mathrm{NO}_{\mathrm{x}}$ reductases in Agrobacterium tumefaciens: the influence of nitrate, nitrite and oxygen availability. Environmental Microbiology, 10, 3070-3081.

Bergaust L, Van Spanning RJ, Frostegard A, Bakken LR (2012) Expression of nitrous oxide reductase in Paracoccus denitrificans is regulated by oxygen and nitric oxide through FnrP and NNR. Microbiology, 158, 826-834.

Betlach MR, Tiedje JM (1981) Kinetic explanation for accumulation of nitrite, nitric oxide, and nitrous oxide during bacterial denitrification. Applied and Environmental Microbiology, 42, 1074-1084. 
Bouwman AF, Beusen AH, Griffioen J et al. (2013) Global trends and uncertainties in terrestrial denitrification and $\mathrm{N}_{2} \mathrm{O}$ emissions. Philosophical Transactions of the Royal Society of London Series B: Biological Sciences, 368, 5.

Butterbach-Bahl K, Baggs EM, Dannenmann M, Kiese R, Zechmeister-Boltenstern S (2013) Nitrous oxide emissions from soils: how well do we understand the processes and their controls? Philosophical Transactions of the Royal Society B: Biological Sciences, 368, 5.

Cavigelli MA, Robertson GP (2001) Role of denitrifier diversity in rates of nitrous oxide consumption in a terrestrial ecosystem. Soil Biology and Biochemistry, 33, 297-310.

Cheneby D, Perrez S, Devroe C et al. (2004) Denitrifying bacteria in bulk and maize-rhizospheric soil: diversity and $\mathrm{N}_{2} \mathrm{O}$-reducing abilities. Canadian Journal of Microbiology, 50, 469-474.

Ciais P, Sabine C, Bala G (2013) Carbon and other biogeochemical cycles. Climate Change 2013: The Physical Science Basis. Contribution of Working Group I to the Fifth Assessment Report of the Intergovernmental Panel on Climate Change.

Dendooven L, Anderson JM (1994) Dynamics of reduction enzymes involved in the denitrification process in pasture soil. Soil Biology and Biochemistry, 26, 1501-1506. 
Dendooven L, Anderson JM (1995) Use of a "least square" optimization procedure to estimate enzyme characteristics and substrate affinities in the denitrification reactions in soil. Soil Biology and Biochemistry, 27, 12611270.

Dendooven L, Splatt P, Anderson JM, Scholefield D (1994) Kinetics of the denitrification process in a soil under permanent pasture. Soil Biology and Biochemistry, 26, 361-370.

Einsle O, Messerschmidt A, Stach P, Bourenkov GP, Bartunik HD, Huber R, Kroneck PM (1999) Structure of cytochrome c nitrite reductase. Nature, 400, 476-480.

Firestone MK, Tiedje JM (1979) Temporal change in nitrous oxide and dinitrogen from denitrification following onset of anaerobiosis. Applied and Environmental Microbiology, 38, 673-679.

Hino T, Matsumoto Y, Nagano S et al. (2010) Structural Basis of Biological $\mathrm{N}_{2} \mathrm{O}$ Generation by Bacterial Nitric Oxide Reductase. Science, 330, 1666-1670.

Holtan-Hartwig L, Dörsch P, Bakken LR (2000) Comparison of denitrifying communities in organic soils: kinetics of $\mathrm{NO}_{3}{ }^{-}$and $\mathrm{N}_{2} \mathrm{O}$ reduction. Soil Biology and Biochemistry, 32, 833-843. 
Jones CM, Spor A, Brennan FP et al. (2014) Recently identified microbial guild mediates soil $\mathrm{N}_{2} \mathrm{O}$ sink capacity. Nature Climate Change, 4, 801-805.

Ka JO, Urbance J, Ye RW, Ahn TY, Tiedje JM (1997) Diversity of oxygen and Noxide regulation of nitrite reductases in denitrifying bacteria. FEMS Microbiology Letters, 156, 55-60.

Kampschreur MJ, Kleerebezem R, Picioreanu C et al. (2012) Metabolic modelling of denitrification in Agrobacterium tumefaciens: a tool to study inhibiting and activating compounds for the denitrification pathway. Frontiers in Microbiology, 3.

Knowles R (1982) Denitrification. Microbiology Reviews, 46, 43-70.

Lloyd D, Boddy L, Davies KJP (1987) Persistence of bacterial denitrification capacity under aerobic conditions: The rule rather than the exception. FEMS Microbiology Letters, 45, 185-190.

Macfarling Meure C, Etheridge D, Trudinger C et al. (2006) Law Dome $\mathrm{CO}_{2}, \mathrm{CH}_{4}$ and $\mathrm{N}_{2} \mathrm{O}$ ice core records extended to 2000 years BP. Geophysical Research Letters, 33, L14810.

Matsumoto Y, Tosha T, Pisliakov AV et al. (2012) Crystal structure of quinoldependent nitric oxide reductase from Geobacillus stearothermophilus. Nature Structural \& Molecular Biology, 19, 238-245. 
Mazoch J, Kunak M, Kucera I, Van Spanning RJ (2003) Fine-tuned regulation by oxygen and nitric oxide of the activity of a semi-synthetic FNR-dependent promoter and expression of denitrification enzymes in Paracoccus denitrificans. Microbiology, 149, 3405-3412.

Moreno-Vivian C, Cabello P, Martinez-Luque M, Blasco R, Castillo F (1999) Prokaryotic nitrate reduction: molecular properties and functional distinction among bacterial nitrate reductases. Journal of Bacteriology, 181, 6573-6584.

Murphy MEP, Turley S, Adman ET (1997) Structure of Nitrite Bound to Coppercontaining Nitrite Reductase from Alcaligenes faecalis : MECHANISTIC IMPLICATIONS. Journal of Biological Chemistry, 272, 28455-28460.

Nobre A, Keller M, Crill P, Harriss R (2001) Short-term nitrous oxide profile dynamics and emissions response to water, nitrogen and carbon additions in two tropical soils. Biology and Fertility of Soils, 34, 363-373.

Nojiri M, Koteishi H, Nakagami T, Kobayashi K, Inoue T, Yamaguchi K, Suzuki S (2009) Structural basis of inter-protein electron transfer for nitrite reduction in denitrification. Nature, 462, 117-120.

Pan Y, Ni B-J, Yuan Z (2013) Modeling Electron Competition among Nitrogen Oxides Reduction and $\mathrm{N}_{2} \mathrm{O}$ Accumulation in Denitrification. Environmental Science and Technology, 47, 11083-11091. 
Parkin TB, Kaspar TC (2006) Nitrous oxide emissions from corn-soybean systems in the midwest. Journal of Environmental Quality, 35, 1496-1506.

Philippot L, Mirleau P, Mazurier S, Siblot S, Hartmann A, Lemanceau P, Germon JC (2001) Characterization and transcriptional analysis of Pseudomonas fluorescens denitrifying clusters containing the nar, nir, nor and nos genes. Biochimca et Biophysica Acta, 16, 436-440.

Pomowski A, Zumft WG, Kroneck PMH, Einsle O (2011) $\mathrm{N}_{2} \mathrm{O}$ binding at a [4Cu:2S] copper-sulphur cluster in nitrous oxide reductase. Nature, 477, 234237.

Ravishankara AR, Daniel JS, Portmann RW (2009) Nitrous Oxide $\left(\mathrm{N}_{2} \mathrm{O}\right)$ : The Dominant Ozone-Depleting Substance Emitted in the 21st Century. Science, 326, 123-125.

Richardson D, Felgate H, Watmough N, Thomson A, Baggs E (2009) Mitigating release of the potent greenhouse gas $\mathrm{N}_{2} \mathrm{O}$ from the nitrogen cycle - could enzymic regulation hold the key? Trends in Biotechnology, 27, 388-397.

Richardson DJ, Berks BC, Russell DA, Spiro S, Taylor CJ (2001) Functional, biochemical and genetic diversity of prokaryotic nitrate reductases. Cellular and Molecular Life Sciences, 58, 165-178. 
Sato N, Ishii S, Sugimoto H et al. (2014) Structures of reduced and ligand-bound nitric oxide reductase provide insights into functional differences in respiratory enzymes. Proteins: Structure, Function, and Bioinformatics, 82, 1258-1271.

Shiro Y (2012) Structure and function of bacterial nitric oxide reductases: Nitric oxide reductase, anaerobic enzymes. Biochimica et Biophysica Acta (BBA) Bioenergetics, 1817, 1907-1913.

Thomsen JK, Geest T, Cox RP (1994) Mass Spectrometric Studies of the Effect of $\mathrm{pH}$ on the Accumulation of Intermediates in Denitrification by Paracoccus denitrificans. Applied and Environmental Microbiology, 60, 536-541.

Venterea RT, Halvorson AD, Kitchen N et al. (2012) Challenges and opportunities for mitigating nitrous oxide emissions from fertilized cropping systems. Frontiers in Ecology and the Environment, 10, 562-570.

Zumft WG (1997) Cell biology and molecular basis of denitrification. Microbiology and Molecular Biology Reviews, 61, 533-616. 


\title{
Chapter 2
}

\section{Modeling Nitrous Oxide Production and Reduction in Soil Through Explicit Representation of Denitrification Enzyme Kinetics ${ }^{\mathrm{I}}$}

\author{
Jianqiu Zheng ${ }^{\dagger}$ and Paul V. Doskey* ${ }^{\dagger}, \ldots$ \\ ${ }^{\dagger}$ Atmospheric Sciences Program, ${ }^{\star}$ Department of Civil and Environmental Engineering, \\ ${ }^{\S}$ School of Forest Resources and Environmental Science, Michigan Technological \\ University, Houghton, Michigan 49931-1295, United States
}

\begin{abstract}
Predictions of nitrous oxide $\left(\mathrm{N}_{2} \mathrm{O}\right)$ emissions from soil using denitrification models, which are based on empirical relationships between microbial production of $\mathrm{N}_{2} \mathrm{O}$ and molecular nitrogen $\left(\mathrm{N}_{2}\right)$ and measureable soil properties, are typically associated with large uncertainties. Current advances in molecular biology reveal elements of transcriptional and post-transcriptional regulatory networks for various denitrifiers that provide a robust regulation of the metabolic response of the denitrification pathway to environmental changes. Thus, including enzyme kinetics in denitrification models is expected to improve simulations of $\mathrm{N}_{2} \mathrm{O}$ emission dynamics. In the subject study, a metabolic model of denitrification based on dual substrate utilization and Monod growth kinetics was developed with explicit representation for denitrification enzymes. Parameterizations were developed from observations of the dynamics of $\mathrm{N}_{2} \mathrm{O}$ production and reduction in soil core incubations with chloramphenicol and acetylene treatments. The model successfully reproduced the dynamics of $\mathrm{N}_{2} \mathrm{O}$ and $\mathrm{N}_{2}$ accumulation in the incubations and
\end{abstract}

\footnotetext{
I The manuscript has been submitted to Environmental Science \& Technology.
} 
revealed an important regulatory effect of denitrification enzyme kinetics on the accumulation of denitrification products. Constitutive denitrification enzymes contributed $23,22,48$, and $78 \%$ of the $\mathrm{N}_{2} \mathrm{O}$ that accumulated in 48 -hr incubations of soil collected from depths of 0-5, 5-10, 10-15, and 15-25 cm, respectively. Incorporating explicit representations of denitrification enzyme kinetics and including parameterizations for constitutive enzymes in process-scale models is a promising approach for simulating dynamics of the production and reduction of $\mathrm{N}_{2} \mathrm{O}$ in soils.

\section{INTRODUCTION}

Application of nitrogen fertilizers to agroecosystems stimulates denitrification and accelerates emissions of nitrous oxide $\left(\mathrm{N}_{2} \mathrm{O}\right)$, which represent about $30 \%$ and $70 \%$ of global and U.S. emissions, respectively. ${ }^{1-3}$ Nitrous oxide is a more potent greenhouse gas than carbon dioxide $\left(\mathrm{CO}_{2}\right)$ and methane and the principal biogenic source of nitrogen oxides in the stratosphere, which contribute to destruction of the ozone layer. ${ }^{4,5}$ Several mechanistic models have been developed to simulate emissions of $\mathrm{N}_{2} \mathrm{O}$ from soil with high spatial and temporal resolution. ${ }^{6}$ Parameterizations of denitrification in DAYCENT, DNDC, DAISY, and ECOSYS assume changes in substrate concentrations are proportional to the size of substrate pools, simple first order kinetics, and the growth of denitrifiers. ${ }^{7-10}$ However, uncertainties in modeled emissions of $\mathrm{N}_{2} \mathrm{O}$ from arable land are large $\mathrm{e}^{6,11}$ and might be reduced through more 
explicit representation of denitrification enzyme kinetics in process-scale models of $\mathrm{N}_{2} \mathrm{O}$ emissions from soil.

Denitrification enables microbes to maintain respiratory metabolism when molecular oxygen $\left(\mathrm{O}_{2}\right)$ is limited and proceeds when respiratory consumption of $\mathrm{O}_{2}$ by plant roots and soil microorganisms exceeds $\mathrm{O}_{2}$ diffusion from the atmosphere. ${ }^{12}$ Nitrogen oxides are used during denitrification as electron acceptors in an electron transport chain similar to the chain used in aerobic respiration. ${ }^{13}$ Nitrate $\left(\mathrm{NO}_{3}{ }^{-}\right)$is reduced sequentially to nitrite $\left(\mathrm{NO}_{2}{ }^{-}\right)$, nitric oxide $(\mathrm{NO}), \mathrm{N}_{2} \mathrm{O}$, and ultimately to molecular nitrogen $\left(\mathrm{N}_{2}\right)$. The sequence of enzymes that catalyzes denitrification are $\mathrm{NO}_{3}{ }^{-}, \mathrm{NO}_{2}{ }^{-}, \mathrm{NO}$, and $\mathrm{N}_{2} \mathrm{O}$ reductases, i.e., $\mathrm{NAR}, \mathrm{NIR}, \mathrm{NOR}$, and $\mathrm{N}_{2} \mathrm{OR}$, respectively.

Denitrification is energetically unfavorable compared to aerobic respiration; ${ }^{14}$ however, a minimum expression of denitrification enzymes may be necessary for survival during the rapid transition from aerobic to anaerobic conditions. Aerobic denitrification was reported for a wide range of denitrifiers, ${ }^{13,15-18}$ which might be attributed (1) to activities from pre-synthesis of the denitrification proteome ${ }^{19}$ that is preserved in soil microsites or (2) a constitutive denitrification pathway that is not controlled by induction and repression. ${ }^{15}$ Constitutive expression of NAR, NIR, and NOR at a high $\mathrm{O}_{2}$ level is a common phenomenon among denitrifiers isolated from the environment, ${ }^{15-18}$ which is generally understood as a protective mechanism against cytotoxic concentrations of $\mathrm{NO}_{2}{ }^{-}$and $\mathrm{NO} \cdot{ }^{13,20}$ Regulatory controls on constitutive denitrification depend on enzyme and transcription level and not on 
differences in $\mathrm{O}_{2}$ sensitivity of the reductases. ${ }^{13}$ Persistence of $\mathrm{N}_{2} \mathrm{OR}$ relative to the other denitrification enzymes is low under aerobic conditions; ${ }^{21}$ however, constitutive expression of $\mathrm{N}_{2} \mathrm{OR}$ was occasionally observed. ${ }^{22}$ Formation of $\mathrm{N}_{2} \mathrm{OR}$ is more likely to be associated with microbial biomass growth as there appears to be no physiological gain from $\mathrm{N}_{2} \mathrm{O}$ reduction in the presence of other, more energetically favorable electron acceptors. ${ }^{23}$

Expression of nos $\mathrm{Z}$ (coding for $\mathrm{N}_{2} \mathrm{OR}$ ) during the transition from aerobic to anaerobic conditions appears to lag behind expression of the other reductase genes, ${ }^{24}$ resulting in transient accumulation of $\mathrm{N}_{2} \mathrm{O}$. Soil incubations showed de novo synthesis of $\mathrm{N}_{2} \mathrm{OR}$ appeared 16-33 h after the establishment of anaerobiosis. ${ }^{25}$ Low persistence of $\mathrm{N}_{2} \mathrm{OR}$ in combination with a lag in activity resulted in a high $\mathrm{N}_{2} \mathrm{O}:\left(\mathrm{N}_{2} \mathrm{O}+\mathrm{N}_{2}\right)$ product ratio as anaerobiosis was rapidly induced. ${ }^{21}$ After anaerobiosis was imposed, de novo synthesis of $\mathrm{NAR}, \mathrm{NIR}$, and $\mathrm{N}_{2} \mathrm{OR}$ were found to occur after $2-3,4-12$, and $24-42 \mathrm{hr}$, respectively. ${ }^{26}$ Transcriptional analysis of cultured Pseudomonas fluorescens C7R12 during the transition from aerobic to anaerobic conditions also demonstrated sequential induction of the denitrification enzymes. $^{27}$

The simple model of denitrification developed by Betlach and Tiedje used Michaelis-Menten type kinetics to explain accumulation of $\mathrm{N}_{2} \mathrm{O}$ in the headspace of aqueous soil slurries. ${ }^{28}$ Dendooven et al. simulated the delayed reduction of $\mathrm{N}_{2} \mathrm{O}$ to $\mathrm{N}_{2}$ by reducing the value of the $\mathrm{N}_{2} \mathrm{O}$ affinity constant in the kinetic expression. ${ }^{26}$ Dual substrate, Michaelis-Menten kinetic models, which incorporate competition 
between reductases for electrons, have also been developed. ${ }^{29,30}$ Pan et al. decoupled carbon oxidation and nitrogen oxide reduction in a denitrification model by introducing reduced and oxidized electron carriers in the Michaelis-Menten kinetic expression and by using different substrate affinity constants to explain competition for electrons. ${ }^{31}$ However, denitrification enzymes that mediate the reactions are not equally induced by substrates and inhibited by $\mathrm{O}_{2} \cdot{ }^{32}$ Lack of representation of denitrification enzyme dynamics from the aforementioned models limits the ability to accurately predict production and reduction of $\mathrm{N}_{2} \mathrm{O}$ in soils.

A novel metabolic denitrification model was developed using a pure culture of Agrobacterium tumefaciens that lacked the nos $\mathrm{Z}$ gene. ${ }^{33}$ The model incorporated enzyme dynamics using transcripts as a proxy of intracellular enzyme concentrations and was able to simulate the sequential accumulation of $\mathrm{NO}$ and $\mathrm{N}_{2} \mathrm{O}$. An unbalanced expression of NIR and NOR was theorized to be responsible for accumulation of NO during the culturing of A. tumefaciens and was explicitly represented in the model with different reaction rates for NO production and reduction in the denitrification pathway. ${ }^{34}$

Enzyme dynamics of the model strain A.tumefaciens were explained at transcription level through advances in understanding of the regulatory metabolism of denitrification. Inoculating 47 soils containing a diverse population of denitrifiers with $A$. tumefaciens, which lacks $\mathrm{N}_{2} \mathrm{OR}$, revealed the indigenous denitrifying community to be an efficient $\mathrm{N}_{2} \mathrm{O}$ sink. ${ }^{35,36}$ The conversion efficiency for $\mathrm{N}_{2} \mathrm{O}$ to $\mathrm{N}_{2}$ is an intrinsic property of different denitrification phenotypes, ${ }^{32}$ and even different 
strains, and thus, generalizing denitrification product stoichiometry to enzyme kinetics and the propensity for emitting $\mathrm{N}_{2} \mathrm{O}$ using selected strains remains problematic. $^{32,37,38}$

Here we apply a dual substrate utilization and microbial growth kinetics model to simulate dynamics of $\mathrm{N}_{2} \mathrm{O}$ production/reduction in aqueous soil slurries incubated under anaerobic conditions. We adapted the concept of constitutive enzymes to separate denitrification activities of pre-synthesized denitrification enzymes from de novo synthesized enzymes; however, the pre-synthesized enzymes may not be strictly constitutive. Thus, treatments with chloramphenicol, which inhibits de novo synthesis of denitrification enzymes, were used to evaluate the activity of constitutive denitrification enzymes. Treatments that included addition of chloramphenicol and acetylene were used to examine the constitutive level of $\mathrm{N}_{2} \mathrm{OR}$ in the soil. Enzyme saturation factors for the denitrification enzymes were derived from the experimental data to approximate active enzyme concentrations. The model accurately predicted the dynamics of $\mathrm{N}_{2} \mathrm{O}$ production/reduction in soils after the onset of anaerobiosis when explicit representation of the constitutive enzyme kinetics was included.

\section{EXPERIMENTAL SECTION}

Soil collection and analysis. Soils were collected 19-26 August 2012 as part of a rainfall simulation study ${ }^{39}$ at the Bondville, Illinois AmeriFlux site $\left(40^{\circ} 00^{\prime} \mathrm{N}\right.$, $\left.88^{\circ} 18^{\prime} \mathrm{W}\right)$. No-till agriculture has been practiced at the site for more than $20 \mathrm{a}$, and soybeans and corn have been rotated annually since $2000 .{ }^{40}$ The soil type is silt 
loam, with an average porosity of $45 \%$ between $0-50 \mathrm{~cm}$ and an inorganic fraction composed of $25 \%$ clay, $70 \%$ silt and $5 \%$ sand. $^{40,41}$

Soil samples were collected in-the-row of soybean down to a depth of $25 \mathrm{~cm}$ using a 1.27-cm o.d. stainless steel sampler (AMS, Inc. American Falls, ID) and sectioned into 4 depth increments (i.e., 0-5, 5-10, 10-15 and 15-25 cm). Soil core sections were stored in 15-mL sterile plastic tubes (Fisher Scientific, Pittsburgh, PA), flashfrozen in the field in liquid $\mathrm{N}_{2}$, and transported to the laboratory in a liquid $\mathrm{N}_{2}$ dewar (PrincetonCryo, Flemington, NJ). Briefly, subsamples from soil cores sections were sieved (4 mm) prior to analyses of soil $\mathrm{pH}, \mathrm{NO}_{3}{ }^{-}$, extractable organic carbon (i.e., dissolved organic carbon; DOC), and microbial biomass carbon (SMBC). Soil pH was determined in a soil suspension using the 1:1 slurry method. The DOC and soil soluble $\mathrm{N}$ were extracted with potassium sulfate and analyzed with a TOC Analyzer (Sievers 900, GE Analytical Instruments, CO) and Rapid Flow Analyzer (Perstorp Analytical Inc., Silver Spring, MD), respectively. The SMBC was determined through a correlation with the phospholipid fatty acid (PLFA) content of soil ${ }^{42,43}$. Lipids were extracted from freeze-dried soils with chloroform-methanol ${ }^{44}$ and the methylated PLFAs were quantified by high-resolution gas chromatography with flame ionization detection (FID; HP6890; Agilent, Palo Alto, CA). Calculation of SMBC was based on the following correlation: ${ }^{39}$

$$
S M B C=4.5 P L F A_{T}+33\left(R^{2}=0.85\right)
$$

Where $S M B C$ and total PLFAs $\left(P L F A_{T}\right)$ are expressed as $\mu \mathrm{g} \mathrm{C} \mathrm{g}^{-1}$ and $\mathrm{nmol} \mathrm{g}{ }^{-1}$. 
Soil Incubations. Subsamples of soil core sections (3 g) sampled before the rainfall simulation were added to $40 \mathrm{~mL}$ amber vials containing $5 \mathrm{~mL}$ of synthetic rainwater and sealed with mininert valves (Sigma Aldrich, MO). The average volumetric air content was between $40-50 \%$ before the incubation. Levels of chemical constituents in the synthetic rainwater were determined from the average concentrations in annual precipitation. ${ }^{45}$ Air was evacuated from the vial headspace for $30 \mathrm{~min}$ and replaced by helium $(\mathrm{He})$ for a total of 3 times to reduce headspace $\mathrm{O}_{2}$ levels to $0.1-0.5 \%(\mathrm{v} / \mathrm{v})$. Treatments with chloramphenicol (CHL; $2.5 \mathrm{~g} \mathrm{~L}^{-1}$ ) were used to inhibit protein synthesis. ${ }^{21}$ To inhibit $\mathrm{N}_{2} \mathrm{OR}$, which reduces $\mathrm{N}_{2} \mathrm{O}$ to $\mathrm{N}_{2}, 3.5$ $\mathrm{mL}$ of $\mathrm{He}$ was removed from the headspace and replaced with acetylene $\left(\mathrm{C}_{2} \mathrm{H}_{2}\right)$ to make the headspace concentration $10 \% \mathrm{v} / \mathrm{v}$. Vials with the various treatments were prepared in triplicate, incubated at $25^{\circ} \mathrm{C}$, and gently mixed on a rotary shaker $(250$ $\mathrm{rpm})$.

The headspace of each vial was sampled at $0,3,6,12,24,36$, and $48 \mathrm{~h}$ to match the sampling schedule of the rainfall simulation study. Samples of headspace were injected into a 1-mL stainless steel sample loop connected to a 2-position, 6-port valve (VICI, Houston, TX) upstream of a high-resolution gas chromatograph with electron capture detector (ECD; HP5890; Hewlett Packard, Palo Alto, CA). The $\mathrm{N}_{2} \mathrm{O}$ was separated from other electron capturing species with a $30-\mathrm{m} \times 0.530-\mathrm{mm}$ fused silica capillary coated with a 3.00- $\mu \mathrm{m}$ carbon film (GS-CarbonPlot; Agilent). The carrier and ECD makeup gases were $\mathrm{He}$ and $\mathrm{N}_{2}$, respectively. The $\mathrm{C}_{2} \mathrm{H}_{2}$ diminished sensitivity and impeded recovery of the ECD, and thus, was removed from the 
column effluent by redirecting the column flow through a 2-position, 4-port valve (VIVI) to an FID after $\mathrm{N}_{2} \mathrm{O}$ eluted from the column. The precision for $\mathrm{N}_{2} \mathrm{O}$ quantitation was better than $2 \%$ and the detection limit was less than $5 \mathrm{ppb}_{\mathrm{v}}$.

Model development. The model is based on dual substrate utilization and Monod growth kinetics. ${ }^{29,30}$ Microbial oxidations of $\mathrm{C}$ via use of $\mathrm{O}_{2}, \mathrm{NO}_{3}{ }^{-}, \mathrm{NO}_{2}{ }^{-}, \mathrm{NO}$, and $\mathrm{N}_{2} \mathrm{O}$ as electron acceptors are considered and stoichiometric relationships are obtained through electron balance between the $\mathrm{C}$ source and electron acceptors. Microbial mediated transformations are assumed to occur in the aqueous phase with equilibrium established for gases $\left(\mathrm{O}_{2}, \mathrm{NO}, \mathrm{N}_{2} \mathrm{O}\right.$ and $\left.\mathrm{N}_{2}\right)$ between the gas and aqueous phase according to Henry's Law. All chemical species follow a timedependent mass balance in the gas and liquid phase. The specific reaction rate follows Monod microbial growth and substrate utilization kinetics that depend upon the maximum utilization rate of the substrate $(\mu)$, active microbial biomass $(B)$, and substrate concentrations $(C)$. A linear dependency of the enzyme saturation factor $(E)$ is included in the rate expressions to approximate active enzyme concentrations. ${ }^{33}$ The net variation in the aqueous concentration of a substrate $\mathrm{C}_{\mathrm{i}, \mathrm{aq}}(i$ $=\mathrm{O}_{2}, \mathrm{NO}_{3}{ }^{-}, \mathrm{NO}_{2}{ }^{-}, \mathrm{NO}, \mathrm{N}_{2} \mathrm{O}$, and $\mathrm{N}_{2}$ ) depends on the rate of its production and consumption by the corresponding biomass $\left(B_{i}\right)$. Denitrifiers typically constitute up to $20 \%$ of the total microbial biomass, ${ }^{46}$ and thus,

$$
B_{\mathrm{NO}_{\overline{3}}}=B_{\mathrm{NO}_{\overline{3}}}=B_{\mathrm{NO}}=B_{\mathrm{N}_{2} \mathrm{O}}=B_{\mathrm{N}_{2}}=0.2 \times B_{\mathrm{O}_{2}} .
$$

Kinetics and stoichiometry of the transformations involving $\mathrm{O}_{2}$ and nitrogen oxides and model parameters are presented in Tables 2.1 and 2.S1, respectively. Respiration 
is blocked by NO through binding to cytochrome oxidase and nM levels of NO can cause substantial inhibition of respiration. ${ }^{47}$ Competitive inhibition from NO increased the apparent value of the Michaelis-Menten constant for $\mathrm{NO}\left(K_{N O}\right)$, which is determined by the Michaelis-Menten constant for $\mathrm{O}_{2},\left(\mathrm{~K}_{\mathrm{O}_{2}}\right)$, the concentration of $\mathrm{NO}$, and the inhibition coefficient $\left(K_{I, N O, O_{2}}\right)$ in the rate expression of $\mathrm{O}_{2}$ respiration. ${ }^{48,49}$ Two molecules of NO are bound to NOR during reduction of NO and substrate inhibition was observed to occur at $\mu \mathrm{M}$ levels. ${ }^{50}$ Thus, the kinetics of NO reduction follows the classic Haldane formula for substrate inhibition. ${ }^{51}$ However, levels of NO in the soil incubations are unlikely to reach $\mu \mathrm{M}$ levels due to the lower levels of initial substrate concentrations.

Soil slurries were sufficiently buffered and remained constant at about $\mathrm{pH} 7$ over $48 \mathrm{hr}$, and thus, inhibition of $\mathrm{N}_{2} \mathrm{OR}$ activity at suboptimal $\mathrm{pH}(6.0)$ is not considered in the model. ${ }^{32,52,53}$ In the absence of inhibitory effects, denitrification rates are related to availability of electron acceptors and donors and active enzymes mediate the reactions. The dimensionless enzyme saturation factor $(E)$, which represents the percentage of active enzymes, is developed to describe denitrification enzyme kinetics and allows quantification of constitutive denitrification enzymes. The value of $E$ in the model is set from $0-1$ with 1 representing maximum activity. The rate of enzyme production/suppression is assumed to follow Michaelis-Menten kinetics. ${ }^{33,54}$ The inhibitory effect of $\mathrm{O}_{2}$ on denitrification enzymes occurs during transcription and post-transcription, ${ }^{24,55-57}$ and thus, $\mathrm{O}_{2}$ inhibition of the de novo synthesis of denitrification enzymes was explicitly modeled (Table 2.2). 
The rate of volatilization of gaseous chemical species from the aqueous phase is calculated as follows: ${ }^{58}$

$$
R_{t r, i}=K_{L}\left(\frac{C_{i, g}}{H_{i}}-C_{i, a q}\right)
$$

where $R_{t r, i}$ is the transfer rate of the chemical species $\left(\mathrm{M} \mathrm{h}^{-1}\right), C_{i, g}$ and $C_{i, a q}$ are gas and liquid phase concentrations (M), $H_{i}$ is Henry's law constant expressed as $\mathrm{L}_{\mathrm{H}_{2} \mathrm{O}}$ $\mathrm{L}_{\text {air }}^{-1}$ and $K_{L}$ is the overall liquid-phase mass transfer coefficient $\left(\mathrm{h}^{-1}\right)$. The value of $K_{L}$ depends on the physicochemical properties of the chemical species and the depth of liquid in the soil slurry. Temporal variations in aqueous-phase concentrations of $\mathrm{O}_{2}, \mathrm{NO}, \mathrm{N}_{2} \mathrm{O}$ and $\mathrm{N}_{2}$ and gas-phase concentrations of $\mathrm{O}_{2}$ and $\mathrm{NO}$ were not determined, which precluded experimental measurement of $K_{L}$ values. However, estimates of $K_{L}$ for $\mathrm{O}_{2}, \mathrm{NO}, \mathrm{N}_{2} \mathrm{O}$ and $\mathrm{N}_{2}$ based on Henry's law constants and reported values of individual gas- and liquid-phase mass transfer coefficients for $\mathrm{H}_{2} \mathrm{O}$ and $\mathrm{CO}_{2}{ }^{58}$ for the soil slurries were $16.1-19.3 \mathrm{~h}^{-1}$ and at the low end of experimentally determined values (19.44-20.16 $\left.\mathrm{h}^{-1}\right)$ from a robotic incubation system. ${ }^{59}$

The system of differential equations generated from Tables 2.1 and 2.2 is solved numerically using Matlab (The Mathworks, Inc., Natick, MA, USA) with ODE solvers. The average time step is about $0.003 \mathrm{~h}$. Initial conditions are assigned according to levels measured in the incubations ${ }^{39}$ including concentrations of $\mathrm{O}_{2}$, $\mathrm{NO}_{3}{ }^{-}, \mathrm{DOC}, \mathrm{SMBC}$, and the status of constitutive enzymes prior to incubation (Table 2.3). Parameters developed and validated in the model were optimized based on the 
least squares method and model fitness was evaluated by calculating the coefficient of determination as follows:

$$
R^{2}=1-\frac{\sum\left(C_{\text {exp }}-C_{\text {model }}\right)^{2}}{\sum\left(C_{\text {exp }}-\overline{C_{\text {exp }}}\right)^{2}}
$$

where $C_{\exp }$ and $C_{\text {model }}$ are experimentally determined and model simulated concentrations, respectively.

\section{RESULTS}

Model Evaluation. Values of kinetic reaction parameters, which were previously estimated and validated by laboratory studies or process-scale models, are well established and are included in the model (Table 2.S1). Parameters constraining dynamics of enzyme synthesis (Table 2.S2) were developed from several sources and were in general agreement. ${ }^{33,54,60,61}$ A low $K_{m}$ value was assigned for the $\mathrm{O}_{2}$ inhibition coefficient for $\mathrm{N}_{2} \mathrm{OR}$ to compensate for the strong inhibitory effect of $\mathrm{O}_{2} .{ }^{60}$ Experimental data collected from incubation of the top layer of soil $(0-5 \mathrm{~cm})$ were used to evaluate the model (Figure 2.1). Levels of $\mathrm{N}_{2} \mathrm{O}$ increased sharply in the headspace of the soil slurry in synthetic rainwater (CTR) within the first $12 \mathrm{~h}$ and then ceased after $24 \mathrm{~h}$ when $\mathrm{N}_{2} \mathrm{O}$ was likely being reduced to $\mathrm{N}_{2}$. Production of $\mathrm{N}_{2} \mathrm{O}$ in the slurry treated with $\mathrm{C}_{2} \mathrm{H}_{2}$ to block $\mathrm{N}_{2} \mathrm{OR}$ followed a similar pattern to CTR; however, $\mathrm{N}_{2} \mathrm{O}$ production continued to increase between $12 \mathrm{~h}$ and $24 \mathrm{~h}$ and remained fairly constant. Production of $\mathrm{N}_{2} \mathrm{O}$ in the $\mathrm{CHL}$ and $\mathrm{CHL}+\mathrm{C}_{2} \mathrm{H}_{2}$ treatments was less than $\mathrm{N}_{2} \mathrm{O}$ production in the CTR and $\mathrm{C}_{2} \mathrm{H}_{2}$ treatments. The CHL treatment prevents 
de novo synthesis of denitrification enzymes, and thus, accumulation of $\mathrm{N}_{2} \mathrm{O}$ during the first few hours of the incubation is attributed to constitutive enzymes in the soil. The difference between CHL and $\mathrm{CHL}+\mathrm{C}_{2} \mathrm{H}_{2}$ treatments is insignificant and implies levels of constitutive $\mathrm{N}_{2} \mathrm{OR}$ were negligible at the onset of anaerobiosis.

A model simulation was performed on the $\mathrm{CHL}+\mathrm{C}_{2} \mathrm{H}_{2}$ treatment to evaluate the status of constitutive enzymes in the soil. Initial concentrations of $\mathrm{O}_{2}, \mathrm{NO}_{3}^{-}, \mathrm{DOC}$, and SMBC are presented in Table 2.3. The $\mathrm{CHL}+\mathrm{C}_{2} \mathrm{H}_{2}$ treatment inhibited de novo synthesis of enzymes and $\mathrm{N}_{2} \mathrm{OR}$ activity, and thus, the only biochemical reactions to consider were $\mathrm{O}_{2}$ respiration and $\mathrm{NO}_{3}{ }^{-}, \mathrm{NO}_{2}^{-}$, and $\mathrm{NO}$ reduction with $\mathrm{N}_{2} \mathrm{O}$ being the final denitrification product. Values of $E$ were estimated from the measured denitrification rates with and without $\mathrm{CHL}$ as follows:

$$
E=R_{C H L} / R_{C T R}
$$

where $E$ is the enzyme saturation value and $R_{C H L}$ and $R_{C T R}$ are the denitrification rates with and without CHL, respectively. Values of $R_{C H L}$ and $R_{C T R}$ were derived from the initial, linear portions of the $\mathrm{N}_{2} \mathrm{O}$ production curves (Figure 2.1). Values of $E_{N A R}, E_{N I R}$, and $E_{N O R}$ were assumed to be equal at the beginning of the simulation $\left(E_{0, N} ;\right.$ Table 2.4) to reduce the complexity of the model parameter sets. Constitutive production of NIR was observed to be greater than NAR. ${ }^{15,62}$ However, $\mathrm{N}_{2} \mathrm{O}$ was the principal denitrification product observed in the subject study, and thus, transient accumulation of $\mathrm{NO}_{2}{ }^{-}$and $\mathrm{NO}$ in the soil slurries is unlikely to be high due to 
cytotoxic effects of the chemical species. The value of $E_{0, N}$ was optimized with experimental data by maximizing $R^{2}$. Dynamics of the levels of $\mathrm{N}_{2} \mathrm{O}$ in the headspace were simulated for the $48 \mathrm{~h}$ incubation and are presented with experimental data in Figure 2.2a.

Maximum enzyme synthesis rates $\left(V_{\max , N A R}, V_{\max , N I R}\right.$, and $\left.V_{\max , N O R}\right)$ were evaluated with data from the experiment with the $\mathrm{C}_{2} \mathrm{H}_{2}$ treatment that inhibited $\mathrm{N}_{2} \mathrm{OR}$ activity. Increases in the rate of denitirification were attributed to the synthesis of NAR, NIR and NOR, and $V_{\max , N A R}, V_{\max , N I R}$, and $V_{\max , N O R}$ were assumed to be equal $\left(V_{\max , l}\right.$; Table 2.4). Estimates were based on $\mathrm{N}_{2} \mathrm{O}$ production rates during the time required for $d e$ novo enzyme synthesis to occur after anaerobiosis was established. Increases in the $\mathrm{N}_{2} \mathrm{O}$ production rate in CTR relative to CHL occurred within 3-6 h. The model simulation with an optimized value of $V_{\max , l}$ indicated $\mathrm{N}_{2} \mathrm{O}$ production reached a plateau after about $25 \mathrm{~h}$, which agreed with the experimental data (Figure $2.2 \mathrm{~b}$ ). The value of $V_{\max , N_{2} O R}\left(V_{\max , 2}\right.$; Table 2.4) was estimated based on the accumulation of $\mathrm{N}_{2} \mathrm{O}$ in CTR and the delay in $\mathrm{N}_{2}$ production calculated from CTR and the $\mathrm{C}_{2} \mathrm{H}_{2}$ treatment. Good agreement between modeled and measured accumulation of $\mathrm{N}_{2} \mathrm{O}$ and $\mathrm{N}_{2}$ was observed (Figure 2.2c, 2.2d).

The model was also used to simulate dynamics of SMBC and denitrification enzymes. The simulated growth of SMBC in CTR was about $10 \%$ of the growth measured in the field during the rainfall simulation study. ${ }^{39}$ The SMBC reached a plateau (3.46 mM C) after $40 \mathrm{~h}$ in the model simulation, and slowly diminished as substrates were consumed. The dynamics of denitrification enzymes were simulated 
in the model as the enzyme saturation factor, $E$. Model simulations of temporal profiles in values of $E$ (Figure 2.S1), which represent the dynamics of the denitrification enzymes, agree with observations that NAR, NIR, NOR, and $\mathrm{N}_{2} \mathrm{OR}$ are induced sequentially. ${ }^{24}$

Model Sensitivity Analysis. The sensitivity analysis was performed by applying variations of $\pm 5, \pm 10, \pm 15$, and $\pm 20 \%$ to the selected model parameter, calculating variations in cumulative concentrations of $\mathrm{NO}_{3}{ }^{-}, \mathrm{NO}_{2}^{-}, \mathrm{NO}, \mathrm{N}_{2} \mathrm{O}$, and $\mathrm{N}_{2}$, and normalizing to the corresponding reference simulation. Key regulators for $\mathrm{N}_{2} \mathrm{OR}$ activity are $K_{E, N_{2} O}$ and $K_{I, N_{2} O R}$ and variations showed the strongest impact on accumulation of $\mathrm{N}_{2} \mathrm{O}$ and $\mathrm{N}_{2}$ and minimal impact on accumulation of $\mathrm{NO}_{3}^{-}, \mathrm{NO}_{2}^{-}$, and NO (Figure 2.3). The value of $V_{\max , 1}$ regulates activities of NAR, NIR, and NOR and determines the sequential flux of $\mathrm{N}$ substrates, and thus, $\mathrm{NO}_{3}{ }^{-}, \mathrm{NO}_{2}{ }^{-}$, and $\mathrm{NO}$ were sensitive to changes in $V_{\max , 1}$ as it created an imbalance between production and reduction rates. Cumulative concentrations $\mathrm{N}_{2} \mathrm{O}$ and $\mathrm{N}_{2}$ were slightly influenced by variations in $V_{\max , 1}$. Changes in $V_{\max , 2}$ had a more direct effect on the accumulation of $\mathrm{N}_{2} \mathrm{O}$ and $\mathrm{N}_{2}$ through regulation of $E_{N 2 O R}$. Variations in the parameter enlarged the imbalance between activities of NAR, NIR, NOR, and $\mathrm{N}_{2} \mathrm{OR}$, resulting in a greater accumulation of $\mathrm{N}_{2} \mathrm{O}$. Values of $V_{\max , 1}$ and $V_{\max , 2}$ regulated the time required for gasphase $\mathrm{N}_{2} \mathrm{O}$ to attain peak levels (Figure 2.S2). However, the influence of $V_{\max , 1}$ on the accumulation of $\mathrm{N}_{2} \mathrm{O}$ and $\mathrm{N}_{2}$ was rather small and changes in $V_{\max , 2}$ had a more direct effect on the accumulation of $\mathrm{N}_{2} \mathrm{O}$ and $\mathrm{N}_{2}$ through regulation of $\mathrm{E}_{\mathrm{N} 2 \mathrm{OR}}$. 
Variation in Production and Reduction of $\mathrm{N}_{2} \mathrm{O}$ with Depth. Transformation rates of $\mathrm{N}_{2} \mathrm{O}$ are regulated by active enzyme concentrations, which are parameterized in the model by $E_{0, N}, V_{\max , 1}$, and $V_{\max , 2}$. The sensitivity analysis demonstrated the roles of the parameters in controlling $\mathrm{N}_{2} \mathrm{O}$ and $\mathrm{N}_{2}$ dynamics of the surface soil (0-5 $\mathrm{cm}$ depth). Temporal variations of $\mathrm{N}_{2} \mathrm{O}$ and $\mathrm{N}_{2}$ during incubations of the 5-10, 10-15, and $15-25 \mathrm{~cm}$ soil core sections were similar to the surface soil and values of $E_{0, N}$, $V_{\max , 1}$, and $V_{\max , 2}$ and $R^{2}$ values are presented in Tables 2.4 and 2.S3, respectively. Simulations indicated maxima in $\mathrm{N}_{2} \mathrm{O}$ accumulation and $\mathrm{N}_{2}$ production shifted to later times with increasing soil depth (Figure 2.4). In general, $\mathrm{N}_{2}$ reached a maximum about $20 \mathrm{~h}$ after peak concentrations of $\mathrm{N}_{2} \mathrm{O}$ were observed with prolonged $\mathrm{N}_{2} \mathrm{O}$ accumulation in deeper soils delaying $\mathrm{N}_{2}$ production. Accumulation of $\mathrm{N}_{2} \mathrm{O}$ and $\mathrm{N}_{2}$ in the surface soil was significantly greater than the accumulation in deeper soils, which is explained by the greater $\mathrm{NO}_{3}^{-}$level, $\mathrm{SMBC}$, and denitrification rate in the surface soil (Table 2.3). Temporal variations of the $\mathrm{N}_{2} \mathrm{O}:\left(\mathrm{N}_{2} \mathrm{O}+\mathrm{N}_{2}\right)$ denitrification product ratio from incubations of the soil core sections demonstrated a strong trend with depth (Figure 2.5).

Role of constitutive enzymes. Contributions from constitutive denitrification enzymes were evaluated by setting $V_{\max , 1}$ to zero to suppress de novo synthesis of NAR, NIR and NOR, and thus, $\mathrm{N}_{2} \mathrm{O}$ accumulation would be attributed solely to the activity of constitutive enzymes. Constitutive enzymes contributed $73,65,54$, and $61 \%$ of the total cumulative $\mathrm{N}_{2} \mathrm{O}$ flux during incubations of the $0-5,5-10,10-15$, and 15-25 cm soil core sections, respectively (Figure 2.6). Contributions of constitutive 
enzymes normalized to SMBC increased with soil depth and were 23,22 , 48, and $78 \%$. Constitutive enzyme activity in the model was parameterized with a non-zero initial value of $E$. Simulations with and without constitutive enzymes showed similar sequential induction of $E$ for the denitrification enzymes (Figure 2.S1). Without the contribution of constitutive enzymes, $E_{N I R}$ and $E_{N O R}$ were significantly lower due to delayed accumulation of $\mathrm{NO}_{2}{ }^{-}$and $\mathrm{NO}$. The value for $E_{\mathrm{N}_{2} \mathrm{OR}}$ was slightly influenced and indicates $V_{\max , 2}$ was the principal rate limiting factor for synthesis of $\mathrm{N}_{2} \mathrm{OR}$.

\section{DISCUSSION}

Parameterizations of $\mathrm{N}_{2} \mathrm{O}$ production via denitrification in soil emission models are related to the growth of microbial biomass; however, the subject study suggests an important contribution to production of $\mathrm{N}_{2} \mathrm{O}$ in soils from constitutive enzymes. Soil incubation studies have demonstrated persistence of denitrification enzymes in soils subjected to aerobic conditions. ${ }^{21,25,63}$ Denitrification activity and product gases observed 1-3 $\mathrm{h}$ after the onset of anaerobiosis during the incubations were ascribed to the activity of constitutive enzymes. ${ }^{63}$ A similar dynamic was observed in the CHL treated soil slurries in which inhibition of de novo enzyme synthesis did not diminish denitrification activity. Increases in headspace concentrations of $\mathrm{N}_{2} \mathrm{O}$ in $\mathrm{CTR}$ indicate the denitrification rate accelerated between 3-6 h (Figure 2.1), which is attributed to de novo synthesis of NAR, NIR, and NOR. Persistence of $\mathrm{N}_{2} \mathrm{OR}$ under aerobic conditions is low, ${ }^{25,63}$ and thus, reduction of $\mathrm{N}_{2} \mathrm{O}$ was observed much later during the incubation (Figure 2.1). 
The synthesis and activity of denitrification enzymes are tightly regulated by availability of $\mathrm{O}_{2}$, which is the energetically, favorable electron acceptor. However, the level of anoxia required for denitrifiers can vary substantially among species and denitrification activity can persist in the presence of $\mathrm{O}_{2} \cdot{ }^{37,38}$ During shifts from anaerobic to aerobic conditions, NAR, NIR, and NOR remained active; however, $\mathrm{N}_{2} \mathrm{OR}$ was inhibited. ${ }^{62,64}$ Assays of enzyme activity and kinetic experiments of gene expression demonstrated that NAR and NIR were actively synthesized under aerobic conditions. ${ }^{65,66}$ Kinetic studies of mRNA of denitrification genes demonstrated active expression within 1-2 $\mathrm{h}$ after the onset of anaerobic conditions, ${ }^{65}$ however, incubations of soil extracted bacteria exhibited detectable activity of denitrification after $40 \mathrm{~h} .{ }^{62}$ The results are in agreement with the subject study and indicate estimates of the synthesis rate of denitrification enzymes are reasonable.

Here we define constitutive enzymes as denitrification enzymes synthesized or preserved under suboptimal $\mathrm{O}_{2}$ conditions. The results indicate the activity of constitutive enzymes is critical in interpreting the kinetics of $\mathrm{N}_{2} \mathrm{O}$ production and contributions of constitutive enzymes to the cumulative $\mathrm{N}_{2} \mathrm{O}$ production increases with increasing soil depth. Denitrifiers in the surface and deep layers of soil appear to be physiologically distinct in their ability to preserve NAR, NIR and NOR activities. The trend might be related to variations in $\mathrm{O}_{2}$ levels with soil depth. Diffusion of $\mathrm{O}_{2}$ diminishes with depth as soils become more compact, which reduces the airspace of soil pores and creates the $\mathrm{O}_{2}$ tension preferred by denitrifiers. The trend might also be related to the composition of the denitrifier communities in deep 
soil layers, which might be composed of denitrifiers with more persistent NAR, NIR, and NOR.

Inhibition of $\mathrm{N}_{2} \mathrm{OR}$ by $\mathrm{O}_{2}$ in the incubations is not a factor and values of the $\mathrm{N}_{2} \mathrm{O}:\left(\mathrm{N}_{2} \mathrm{O}+\mathrm{N}_{2}\right)$ product ratio is related to the kinetics of denitrification. The plateau stage during the initial 5-10 h of the incubations is characterized by minimum $\mathrm{N}_{2}$ production, which could be attributed to the activity of constitutive enzymes and delay in $\mathrm{N}_{2} \mathrm{OR}$ synthesis (Figure 2.5). The $\mathrm{N}_{2} \mathrm{O}:\left(\mathrm{N}_{2} \mathrm{O}+\mathrm{N}_{2}\right)$ product ratio approached zero in response to prolonged $(40 \mathrm{~h})$ incubation under anaerobic conditions (Figure 2.S1), which is attributed to an increase in $\mathrm{N}_{2} \mathrm{OR}$ activity. ${ }^{23}$ The $\mathrm{N}_{2} \mathrm{O}:\left(\mathrm{N}_{2} \mathrm{O}+\mathrm{N}_{2}\right)$ product ratio was greater in the deeper layers of the soil, which indicates the time required for $\mathrm{N}_{2} \mathrm{O}$ reduction increased with depth in the soil. The trend is well correlated with an increasing contribution of constitutive enzymes to the cumulative $\mathrm{N}_{2} \mathrm{O}$ production with depth in soil. Trends in the product ratio are sensitive to changes in the soil environment. For example, reaeration of the soil can interrupt $\mathrm{N}_{2}$ production and increase the $\mathrm{N}_{2} \mathrm{O}:\left(\mathrm{N}_{2} \mathrm{O}+\mathrm{N}_{2}\right)$ product ratio. ${ }^{62}$

The soil incubation experiments and model simulations demonstrate constitutive denitrification enzymes that reduce $\mathrm{NO}_{3}{ }^{-}$to $\mathrm{N}_{2} \mathrm{O}$ make a significant contribution to the rapid production of $\mathrm{N}_{2} \mathrm{O}$ during the early stages of denitrification. However, $\mathrm{N}_{2} \mathrm{OR}$ generally does not persist in aerated soils, and thus, reduction of $\mathrm{N}_{2} \mathrm{O}$ to $\mathrm{N}_{2}$ requires a soil environment with low $\mathrm{O}_{2}$ tension. Fluctuations of the production and reduction of $\mathrm{N}_{2} \mathrm{O}$ are regulated by the unbalanced activity of denitrification enzymes, which are sensitive to soil environmental conditions. Explicit representation of 
denitrification enzyme kinetics in process-scale models that include representations for constitutive enzymes is a promising approach for reducing uncertainties in model predictions of $\mathrm{N}_{2} \mathrm{O}$ emissions from soil.

\section{ASSOCIATED CONTENT}

\section{Supporting Information}

Additional tables with references and figures are provided.

\section{AUTHOR INFORMATION}

\section{Corresponding Author}

*E-mail: pvdoskey@mtu.edu. Phone: 906-487-2745. Fax: 906-487-2943.

\section{Notes}

The authors declare no competing financial interest.

\section{ACKNOWLEDGEMENTS}

The authors acknowledge start-up funding, which supported Jianqiu Zheng, and an equipment loan to Paul V. Doskey through Michigan Technological University and Argonne National Laboratory, respectively. Partial support for Jianqiu Zheng through the Atmospheric Sciences Program is also greatly appreciated.

\section{REFERENCES}


(1) Kroeze, C.; Mosier, A.; Bouwman, L., Closing the global $\mathrm{N}_{2} \mathrm{O}$ budget: A retrospective analysis 1500-1994. Global Biogeochem Cy. 1999, 13, 1-8.

(2) Sowers, T.; Rodebaugh, A.; Yoshida, N.; Toyoda, S., Extending records of the isotopic composition of atmospheric $\mathrm{N}_{2} \mathrm{O}$ back to 1800 A.D. from air trapped in snow at the South Pole and the Greenland Ice Sheet Project II ice core. Global Biogeochem. Cy. 2002, 16, 1129, doi:1110.1029/2002GB001911.

(3) USEPA, Inventory of U.S. Greenhouse Gas Emissions and Sinks: 1990-2007, http://epa.gov/climatechange/emissions/usinventoryreport.html, 2009.

(4) Seinfeld, J. H.; Pandis, S. N., Atmospheric Chemistry and Physics, John Wiley and Sons, New York, 1998.

(5) Ravishankara, A. R.; Daniel, J. S.; Portmann, R. W., Nitrous Oxide $\left(\mathrm{N}_{2} \mathrm{O}\right)$ : The dominant ozone-depleting substance emitted in the 21st Century. Science 2009, 326, 123-125.

(6) Boyer, E. W.; Alexander, R. B.; Parton, W. J.; Li, C.; Butterbach-Bahl, K.; Donner, S. D.; Skaggs, R. W.; Del Grosso, S. J., Modeling denitrification in terrestrial and aquatic ecosystems at regional scales. Ecol. Appl. 2006, 16, 2123 2142. 
(7) Del Grosso, S. J.; Parton, W. J.; Mosier, A. R.; Ojima, D. S.; Kulmala, A. E.; Phongpan, S., General model for $\mathrm{N}_{2} \mathrm{O}$ and $\mathrm{N}_{2}$ gas emissions from soils due to dentrification. Global Biogeochem. Cy. 2000, 14, 1045-1060.

(8) Grant, R. F.; Pattey, E., Modelling variability in $\mathrm{N}_{2} \mathrm{O}$ emissions from fertilized agricultural fields. Soil Biol. Biochem. 2003, 35, 225-243.

(9) Hansen, S.; Jensen, H. E.; Nielsen, N. E.; Svendsen, H., Simulation of nitrogen dynamics and biomass production in winter wheat using the Danish simulation model DAISY. Fert. Res. 1991, 27, 245-259.

(10) Li, C.; Frolking, S.; Frolking, T. A., A model of nitrous oxide evolution from soil driven by rainfall events: 1. Model structure and sensitivity. J. Geophys. Res. 1992, 97, 9759-9776.

(11) Lim, B.; Boileau, P.; Bonduki, Y.; van Amstel, A. R.; Janssen, L. H. J. M.; Olivier, J. G. J.; Kroeze, C., Improving the quality of national greenhouse gas inventories. Environ. Sci. Policy 1999, 2, 335-346.

(12) Firestone, M. K.; Davidson, E. A., Microbiological basis of $\mathrm{NO}$ and $\mathrm{N}_{2} \mathrm{O}$ production and consumption in soil. In: Exchange of Trace Gases Between 
Terrestrial Ecosystems and the Atmosphere, Andreae, M. O.; Schimel, D. S. (eds), pp. 7-21, John Wiley and Sons, Chichester, 1989.

(13) Zumft, W. G., Cell biology and molecular basis of denitrification. Microbiol. Mol. Biol. R. 1997, 61, 533-616.

(14) Thauer, R. K.; Jungermann, K.; Decker, K., Energy conservation in chemotrophic anaerobic bacteria. Bacteriol. Rev. 1977, 41, 100-180.

(15) Ka, J. O.; Urbance, J.; Ye, R. W.; Ahn, T. Y.; Tiedje, J. M., Diversity of oxygen and $\mathrm{N}$-oxide regulation of nitrite reductases in denitrifying bacteria. FEMS Microbiol. Lett. 1997, 156, 55-60.

(16) Lloyd, D.; Boddy, L.; Davies, K. J. P., Persistence of bacterial denitrification capacity under aerobic conditions: The rule rather than the exception. FEMS Microbiol. Lett. 1987, 45, 185-190.

(17) Takaya, N.; Catalan-Sakairi, M. A. B.; Sakaguchi, Y.; Kato, I.; Zhou, Z.;

Shoun, H., Aerobic denitrifying bacteria that produce low levels of nitrous oxide. Appl. Environ. Microb. 2003, 69, 3152-3157. 
(18) Robertson, L.; Kuenen, J. G., Aerobic denitrification: a controversy revived. Arch. Microbiol. 1984, 139, 351-354.

(19) Richardson, D.; Felgate, H.; Watmough, N.; Thomson, A.; Baggs, E., Mitigating release of the potent greenhouse gas $\mathrm{N}_{2} \mathrm{O}$ from the nitrogen cycle - Could enzymatic regulation hold the key? Trends Biotechnol. 2009, 27, 388-397.

(20) Knowles, R., Denitrification. Microbiol. Rev. 1982, 46, 43-70.

(21) Dendooven, L.; Anderson, J. M., Dynamics of reduction enzymes involved in the denitrification process in pasture soil. Soil Biol. Biochem. 1994, 26, 1501-1506.

(22) Miyahara, M.; Kim, S.-W.; Fushinobu, S.; Takaki, K.; Yamada, T.; Watanabe, A.; Miyauchi, K.; Endo, G.; Wakagi, T.; Shoun, H., Potential of aerobic denitrification by Pseudomonas stutzeri TR2 to reduce nitrous oxide emissions from wastewater treatment plants. Appl. Environ. Microb. 2010, 76, 4619-4625.

(23) Bakken, L. R.; Dorsch, P., Nitrous oxide emission and global changes: Modeling approaches. In: Biology of the Nitrogen Cycle, Bothe, H.; Ferguson, S. J.; Newton, W. E. (eds), pp. 381-395, Elsevier, New York, 2007. 
(24) van Spanning, R. J. M.; Richardson, D. J.; Ferguson, S. j., Introduction to the biochemistry and molecular biology of denitrification. In: Biology of the Nitrogen Cycle, Bothe, H.; Ferguson, S. J.; Newton, W. E. (eds), pp. 7-21, Elsevier, New York, 2007.

(25) Firestone, M. K.; Tiedje, J. M., Temporal change in nitrous oxide and dinitrogen from denitrification following onset of anaerobiosis. Appl. Environ. Microb. 1979, 38, 673-679.

(26) Dendooven, L.; Anderson, J. M., Use of a "least square" optimization procedure to estimate enzyme characteristics and substrate affinities in the denitrification reactions in soil. Soil Biol. Biochem. 1995, 27, 1261-1270.

(27) Philippot, L.; Mirleau, P.; Mazurier, S.; Siblot, S.; Hartmann, A.; Lemanceau, P.; Germon, J. C., Characterization and transcriptional analysis of Pseudomonas fluorescens denitrifying clusters containing the nar, nir, nor and nos genes. $B B A$ Gene Struct. Expr. 2001, 16, 436-440.

(28) Betlach, M. R.; Tiedje, J. M., Kinetic explanation for accumulation of nitrite, nitric oxide, and nitrous oxide during bacterial denitrification. Appl. Environ. Microb. 1981, 42, 1074-1084. 
(29) Almeida, J. S.; Reis, M. A. M.; Carrondo, M. J. T., A unifying kinetic model of denitrification. J. Theor. Biol. 1997, 186, 241-249.

(30) Thomsen, J. K.; Geest, T.; Cox, R. P., Mass spectrometric studies of the effect of $\mathrm{pH}$ on the accumulation of intermediates in denitrification by Paracoccus denitrificans. Appl. Environ. Microbiol. 1994, 60, 536-541.

(31) Pan, Y.; Ni, B.-J.; Yuan, Z., Modeling electron competition among nitrogen oxides reduction and $\mathrm{N}_{2} \mathrm{O}$ accumulation in denitrification. Environ. Sci. Technol. 2013, 47, 11,083-11,091.

(32) Bakken, L. R.; Bergaust, L.; Liu, B.; Frostegård, Å., Regulation of denitrification at the cellular level: A clue to the understanding of $\mathrm{N}_{2} \mathrm{O}$ emissions from soils. Philos. T. Roy. Soc. B 2012, 367, 1226-1234.

(33) Kampschreur, M. J.; Kleerebezem, R.; Picioreanu, C.; Bakken, L.; Bergaust, L.; de Vries, S.; Jetten, M. S.; van Loosdrecht, M. C., Metabolic modeling of denitrification in Agrobacterium tumefaciens: A tool to study inhibiting and activating compounds for the denitrification pathway. Front. Microbiol 2012, 3, 119. 
(34) Bergaust, L.; Shapleigh, J.; Frostegård, Å.; Bakken, L., Transcription and activities of $\mathrm{NO}_{\mathrm{x}}$ reductases in Agrobacterium tumefaciens: The influence of nitrate, nitrite and oxygen availability. Environ. Microbiol. 2008, 10, 3070-3081.

(35) Philippot, L.; Andert, J.; Jones, C. M.; Bru, D.; Hallin, S., Importance of denitrifiers lacking the genes encoding the nitrous oxide reductase for $\mathrm{N}_{2} \mathrm{O}$ emissions from soil. Glob. Change Biol. 2011, 17, 1497-1504.

(36) Jones, C. M.; Spor, A.; Brennan, F. P.; Breuil, M.-C.; Bru, D.; Lemanceau, P.; Griffiths, B.; Hallin, S.; Philippot, L., Recently identified microbial guild mediates soil $\mathrm{N}_{2} \mathrm{O}$ sink capacity. Nature Clim. Change 2014, 4, 801-805.

(37) Cavigelli, M. A.; Robertson, G. P., Role of denitrifier diversity in rates of nitrous oxide consumption in a terrestrial ecosystem. Soil Biol. Biochem. 2001, 33, 297-310.

(38) Cheneby, D.; Perrez, S.; Devroe, C.; Hallet, S.; Couton, Y.; Bizouard, F.; Iuretig, G.; Germon, J. C.; Philippot, L., Denitrifying bacteria in bulk and maizerhizospheric soil: Diversity and $\mathrm{N}_{2} \mathrm{O}$-reducing abilities. Can. J. Microbiol. 2004, 50, 469-474. 
(39) Zheng, J. \& Doskey, P.V. Dynamics of nitrous oxide in soil gas and surface fluxes following simulation of sequential precipitation events. Glob. Change Bio. submitted, 2014.

(40) Bondville AmeriFlux Site, AmeriFlux US-Bo1 sponsored by NOAA/GEWEX http://ameriflux.ornl.gov/fullsiteinfo.php?sid=44., 2012.

(41) Illinois Climate Network, sponsored by Illinois State Water Survey http://www.isws.illinois.edu/warm/datatype.asp., 2012.

(42) Leckie, S. E.; Prescott, C. E.; Grayston, S. J.; Neufeld, J. D.; Mohn, W. W., Comparison of chloroform fumigation-extraction, phospholipid fatty acid, and DNA methods to determine microbial biomass in forest humus. Soil Biol. Biochem. 2004, $36,529-532$.

(43) Bailey, V. L.; Peacock, A. D.; Smith, J. L.; Bolton Jr., H., Relationships between soil microbial biomass determined by chloroform fumigation-extraction, substrate-induced respiration, and phospholipid fatty acid analysis. Soil Biol. Biochem. 2002, 34, 1385-1389.

(44) Bligh, E. G.; Dyer, W. J., A rapid method of total lipid extraction and purification. Can. J. Biochem. Physiol. 1959, 37, 911-917. 
(45) NADP, National Atmospheric Depostion Program

http://nadp.isws.illinois.edu/., 2012.

(46) Tiedje, J. M., Ecology of denitrification and dissimilatory nitrate reduction to ammonium. In: Environmental Microbiology of Anaerobes, Zehnder, A.J.B. (ed), pp. 179-244, John Wiley and Sons, New York, 1988.

(47) Giuffre, A.; Borisov, V. B.; Mastronicola, D.; Sarti, P.; Forte, E., Cytochrome bd oxidase and nitric oxide: From reaction mechanisms to bacterial physiology. FEBS Lett. 2012, 586, 622-629.

(48) Koivisto, A.; Matthias, A.; Bronnikov, G.; Nedergaard, J., Kinetics of the inhibition of mitochondrial respiration by NO. FEBS Lett. 1997, 417, 75-80.

(49) Copeland, R. A., Time-dependent inhibition. In: Enzymes, pp. 318-349, John Wiley and Sons, New York, 2002.

(50) Girsch, P.; de Vries, S., Purification and initial kinetic and spectroscopic characterization of NO reductase from Paracoccus denitrificans. BBA-Bioenergetics $1997,16,1-2$. 
(51) Copeland, R. A., Kinetics of single-substrate enzyme reactions. In Enzymes, pp. 109-145, John Wiley and Sons, New York, 2002.

(52) Bergaust, L.; Mao, Y.; Bakken, L. R.; Frostegård, Å., Denitrification response patterns during the transition to anoxic respiration and posttranscriptional effects of suboptimal pH on nitrogen oxide reductase in Paracoccus denitrificans. Appl. Environ. Microb. 2010, 76, 6387-6396.

(53) Liu, B.; Morkved, P. T.; Frostegård, Å.; Bakken, L. R., Denitrification gene pools, transcription and kinetics of $\mathrm{NO}, \mathrm{N}_{2} \mathrm{O}$ and $\mathrm{N}_{2}$ production as affected by soil pH. FEMS Microbiol. Ecol. 2010, 72, 407-417.

(54) Blagodatsky, S.; Grote, R.; Kiese, R.; Werner, C.; Butterbach-Bahl, K., Modelling of microbial carbon and nitrogen turnover in soil with special emphasis on N-trace gases emission. Plant Soil 2011, 346, 297-330.

(55) Bergaust, L.; van Spanning, R. J.; Frostegård, Å.; Bakken, L. R., Expression of nitrous oxide reductase in Paracoccus denitrificans is regulated by oxygen and nitric oxide through FnrP and NNR. Microbiology 2012, 158, 826-834.

(56) Hartsock, A.; Shapleigh, J. P., Mechanisms of oxygen inhibition of nirK expression in Rhodobacter sphaeroides. Microbiology 2010, 156, 3158-3165. 
(57) Mazoch, J.; Kunak, M.; Kucera, I.; Van Spanning, R. J., Fine-tuned regulation by oxygen and nitric oxide of the activity of a semi-synthetic FNR-dependent promoter and expression of denitrification enzymes in Paracoccus denitrificans. Microbiology 2003, 149, 3405-3412.

(58) Thibodeaux, L. J., Environmental Chemodynamics. John Wiley and Sons, New York, 1996.

(59) Molstad, L.; Dorsch, P.; Bakken, L. R., Robotized incubation system for monitoring gases $\left(\mathrm{O}_{2}, \mathrm{NO}, \mathrm{N}_{2} \mathrm{O}, \mathrm{N}_{2}\right)$ in denitrifying cultures. J. Microbiol. Meth. 2007, 71, 202-211.

(60) Conrad, R., Soil microorganisms as controllers of atmospheric trace gases $\left(\mathrm{H}_{2}, \mathrm{CO}, \mathrm{CH}_{4}, \mathrm{OCS}, \mathrm{N}_{2} \mathrm{O}\right.$, and NO). Microbiol. Rev. 1996, 60, 609-640.

(61) Korner, H.; Zumft, W. G., Expression of denitrification enzymes in response to the dissolved oxygen level and respiratory substrate in continuous culture of Pseudomonas stutzeri. Appl Environ Microb. 1989, 55, 1670-1676.

(62) Morley, N.; Baggs, E. M.; Dorsch, P.; Bakken, L., Production of NO, $\mathrm{N}_{2} \mathrm{O}$ and $\mathrm{N}_{2}$ by extracted soil bacteria, regulation by $\mathrm{NO}_{2}{ }^{-}$and $\mathrm{O}_{2}$ concentrations. FEMS Microbiol. Ecol. 2008, 65, 102-112. 
(63) Smith, M. S.; Tiedje, J. M., Phases of denitrification following oxygen depletion in soil. Soil Biol. Biochem. 1979, 11, 261-267.

(64) Otte, S.; Grobben, N. G.; Robertson, L. A.; Jetten, M. S.; Kuenen, J. G., Nitrous oxide production by Alcaligenes faecalis under transient and dynamic aerobic and anaerobic conditions. Appl. Environ. Microb. 1996, 62, 2421-2426.

(65) Härtig, E.; Zumft, W. G., Kinetics of nirS expression (Cytochromecd 1 Nitrite Reductase) in Pseudomonas stutzeri during the transition from aerobic respiration to denitrification: Evidence for a denitrification-specific nitrate- and nitrite-responsive regulatory system. J. Bacteriol. 1999, 181, 161-166.

(66) Patureau, D.; Bernet, N.; Moletta, R., Study of the denitrifying enzymatic system of Comamonas sp. strain SGLY2 under various aeration conditions with a particular view on nitrate and nitrite reductases. Curr. Microbiol. 1996, 32, 25-32. 
Table 2.1 Rate expressions for Monod growth kinetics ${ }^{\mathrm{a}}$

\begin{tabular}{|c|c|}
\hline Biological Reactions & Rate Expressions \\
\hline $\mathrm{CH}_{2} \mathrm{O}+\mathrm{O}_{2}(a q) \rightarrow \mathrm{CO}_{2}(a q)+\mathrm{H}_{2} \mathrm{O}$ & $R_{O_{2}}=\mu_{O_{2}} \cdot B_{O_{2}} \cdot \frac{C_{O_{2}}}{K_{O_{2}}\left(1+\frac{C_{N O}}{K_{I, N O, O_{2}}}\right)+C_{O_{2}}} \cdot \frac{C_{O C}}{K_{O C}+C_{O C}}$ \\
\hline $2 \mathrm{NO}_{3}^{-}+\mathrm{CH}_{2} \mathrm{O} \rightarrow 2 \mathrm{NO}_{2}^{-}+\mathrm{CO}_{2}(a q)+\mathrm{H}_{2} \mathrm{O}$ & $R_{\mathrm{NO}_{3}^{-}}=\mu_{\mathrm{NO}_{3}^{-}} \cdot B_{\mathrm{NO}_{3}^{-}} \cdot \frac{C_{\mathrm{NO}_{3}^{-}}}{K_{\mathrm{NO}_{3}^{-}}+C_{\mathrm{NO}_{3}^{-}}} \cdot \frac{C_{\mathrm{OC}}}{K_{O C}+C_{\mathrm{OC}}} \cdot E_{\mathrm{NAR}}$ \\
\hline $4 \mathrm{NO}_{2}^{-}+\mathrm{CH}_{2} \mathrm{O}+4 \mathrm{H}^{+} \rightarrow 4 \mathrm{NO}(a q)+\mathrm{CO}_{2}(a q)+3 \mathrm{H}_{2} \mathrm{O}$ & $R_{\mathrm{NO}_{2}^{-}}=\mu_{\mathrm{NO}_{2}^{-}} \cdot B_{\mathrm{NO}_{2}^{-}} \cdot \frac{C_{\mathrm{NO}_{2}^{-}}}{K_{\mathrm{NO}_{2}^{-}}+C_{\mathrm{NO} O_{2}^{-}}} \cdot \frac{C_{\mathrm{OC}}}{K_{O C}+C_{O C}} \cdot E_{\mathrm{NIR}}$ \\
\hline $8 \mathrm{NO}(a q)+2 \mathrm{CH}_{2} \mathrm{O} \rightarrow 4 \mathrm{~N}_{2} \mathrm{O}(a q)+2 \mathrm{CO}_{2}(a q)+2 \mathrm{H}_{2} \mathrm{O}$ & $R_{N O}=\mu_{N O} \cdot B_{N O} \cdot \frac{C_{N O}^{2}}{\left[K_{N O}+C_{N O} \cdot\left(1+\frac{C_{N O}}{K_{I, N O}}\right)\right]^{2}} \cdot \frac{C_{O C}}{K_{O C}+C_{O C}} \cdot E_{N O R}$ \\
\hline $4 \mathrm{~N}_{2} \mathrm{O}(a q)+2 \mathrm{CH}_{2} \mathrm{O} \rightarrow 4 \mathrm{~N}_{2}(a q)+2 \mathrm{CO}_{2}(a q)+2 \mathrm{H}_{2} \mathrm{O}$ & $R_{\mathrm{N}_{2} \mathrm{O}}=\mu_{\mathrm{N}_{2} \mathrm{O}} \cdot B_{\mathrm{N}_{2} \mathrm{O}} \cdot \frac{C_{\mathrm{N}_{2} \mathrm{O}}}{K_{\mathrm{N}_{2} \mathrm{O}}+C_{\mathrm{N}_{2} \mathrm{O}}} \cdot \frac{C_{O C}}{K_{O C}+C_{O C}} \cdot E_{\mathrm{N}_{2} \mathrm{OR}}$ \\
\hline
\end{tabular}

${ }^{\mathrm{a}}$ Variables and parameters are listed in Table 2.S1. 
Table 2.2 Enzyme production/suppression kinetics

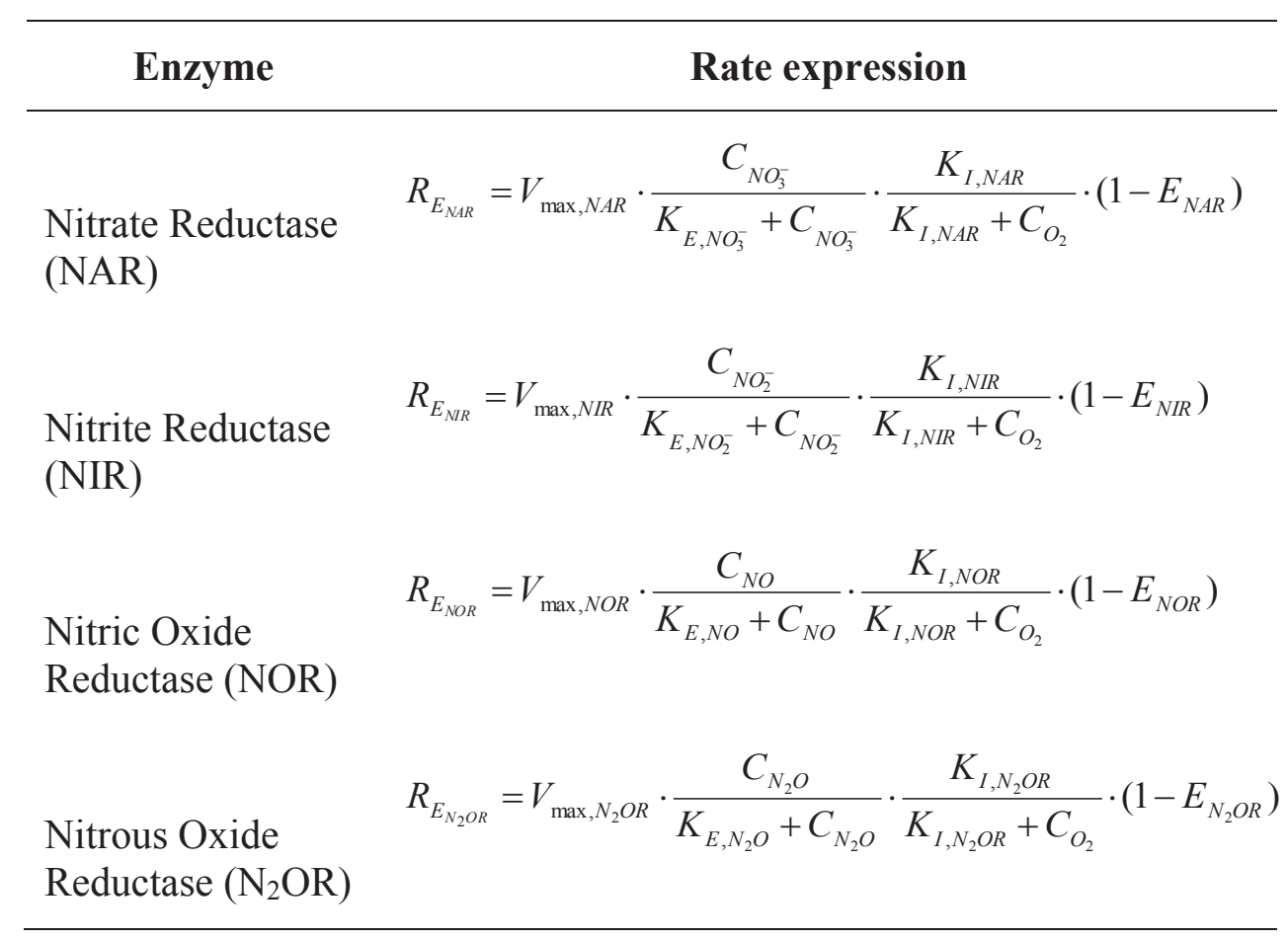


Table 2.3 Initial conditions for incubations of the soil core sections

\begin{tabular}{lcccc}
\hline & $\mathbf{0 - 5} \mathbf{~ c m}$ & $\mathbf{5 - 1 0} \mathbf{~ m}$ & $\mathbf{1 0 - 1 5} \mathbf{~ c m}$ & $\mathbf{1 5 - 2 5} \mathbf{~ c m}$ \\
\hline$\left[\mathrm{NO}_{3}{ }^{-}\right](\mathrm{mM})$ & 0.05 & 0.03 & 0.03 & 0.03 \\
{$[\mathrm{DOC}](\mathrm{mM})$} & 18.5 & 17.1 & 17.9 & 23.7 \\
{$[\mathrm{SMBC}](\mathrm{mM})$} & 3.14 & 2.88 & 1.12 & 0.78 \\
{$\left[\mathrm{O}_{2}\right]_{\mathrm{g}}(\mu \mathrm{M})$} & 40 & 40 & 40 & 40 \\
$R_{C H L} / R_{\text {CTR }}$ & 0.45 & 0.24 & 0.26 & 0.54 \\
\hline
\end{tabular}


Table 2.4 Model parameter estimations for soil core sections

\begin{tabular}{lcccc}
\hline & $\mathbf{0 - 5} \mathbf{~ c m}$ & $\mathbf{5 - 1 0} \mathbf{~ c m}$ & $\mathbf{1 0 - 1 5} \mathbf{~ c m}$ & $\mathbf{1 5 - 2 5} \mathbf{~ c m}$ \\
\hline$E_{0, N}$ & 0.42 & 0.23 & 0.26 & 0.46 \\
$V_{\max , 1^{\mathrm{a}}}$ & 0.4 & 0.1 & 0.2 & 0.8 \\
$V_{\max , 2^{\mathrm{a}}}$ & 0.01 & 0.02 & 0.08 & 0.015 \\
\hline
\end{tabular}

aParameters used in the sensitivity analysis. 


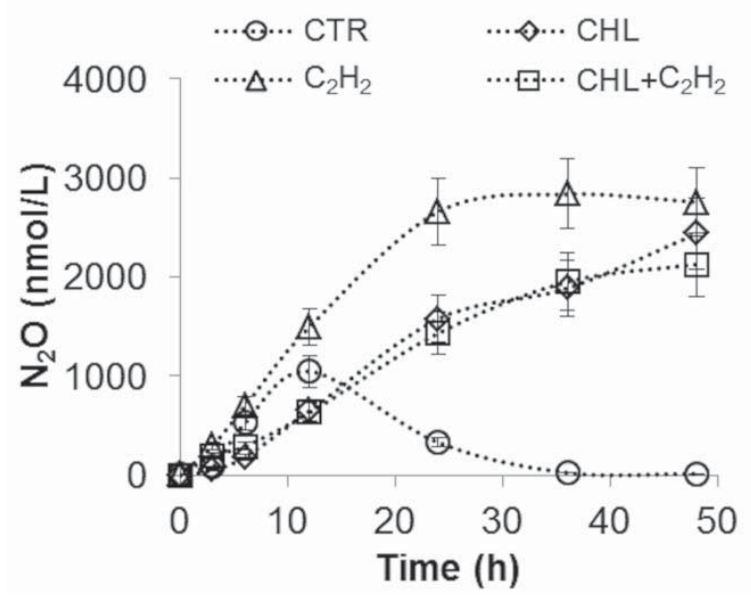

Figure 2.1 Temporal variation of $\mathrm{N}_{2} \mathrm{O}$ concentrations in the helium $(\mathrm{He})$ headspace of the $0-5 \mathrm{~cm}$ soil core section incubated in synthetic rainwater. (CTR, synthetic rainwater; $\mathrm{CHL}$, synthetic rainwater containing chloramphenicol; $\mathrm{C}_{2} \mathrm{H}_{2}, \mathrm{He}$ headspace containing acetylene; $\mathrm{CHL}+\mathrm{C}_{2} \mathrm{H}_{2}$, synthetic rainwater containing chloramphenicol with He headspace containing acetylene). 

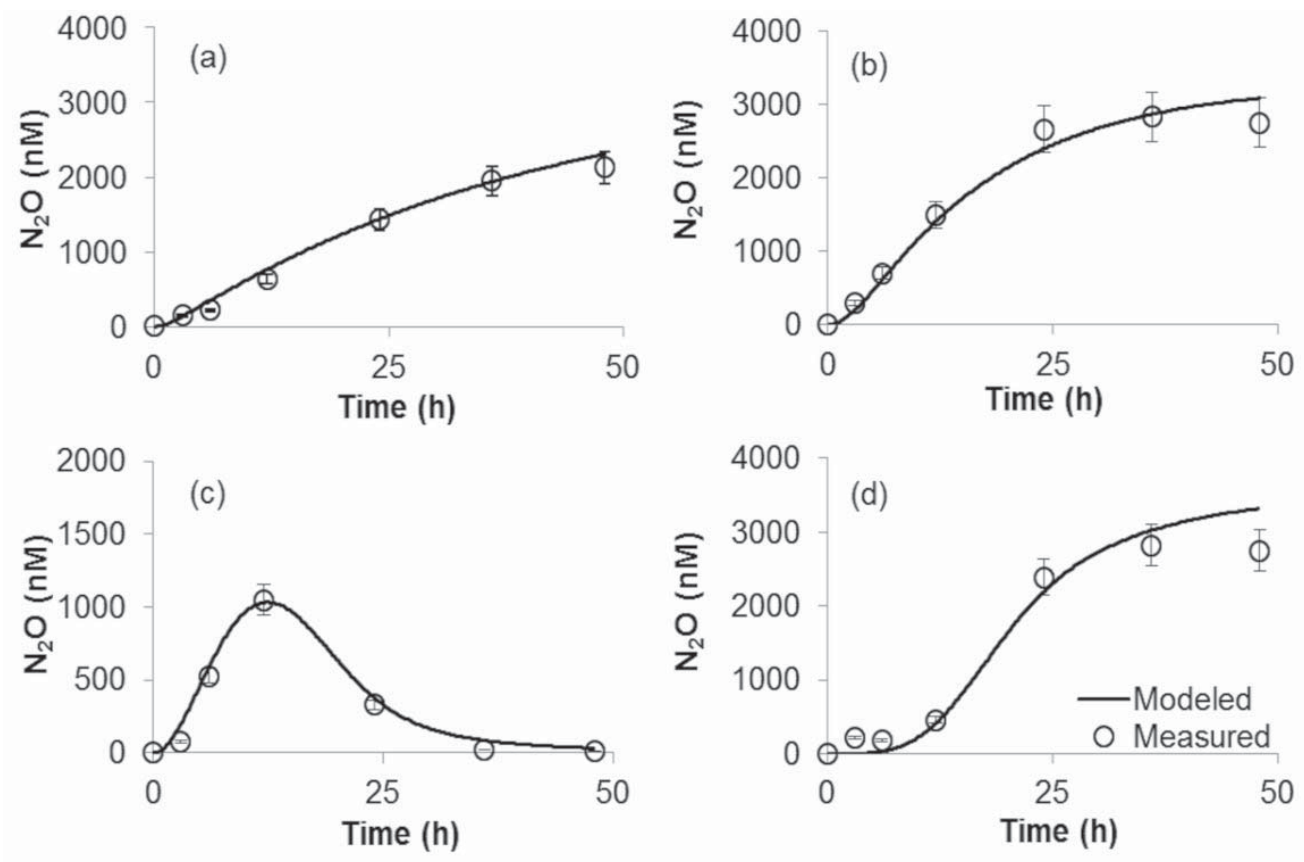

Figure 2.2 Comparison of the measured concentration of $\mathrm{N}_{2} \mathrm{O}$ in the helium headspace of the $0-5 \mathrm{~cm}$ soil core section incubated in synthetic rainwater with the model results: (a) $\mathrm{CHL}+\mathrm{C}_{2} \mathrm{H}_{2} ; \mathrm{E}_{0, \mathrm{~N}}=0.42$, (b) $\mathrm{C}_{2} \mathrm{H}_{2} ; \mathrm{V}_{\max , 1}=0.40$, (c) CTR; $\mathrm{V}_{\max , 2}=$ 0.01 , and (d) $\mathrm{N}_{2} \mathrm{O}$ reduction. 


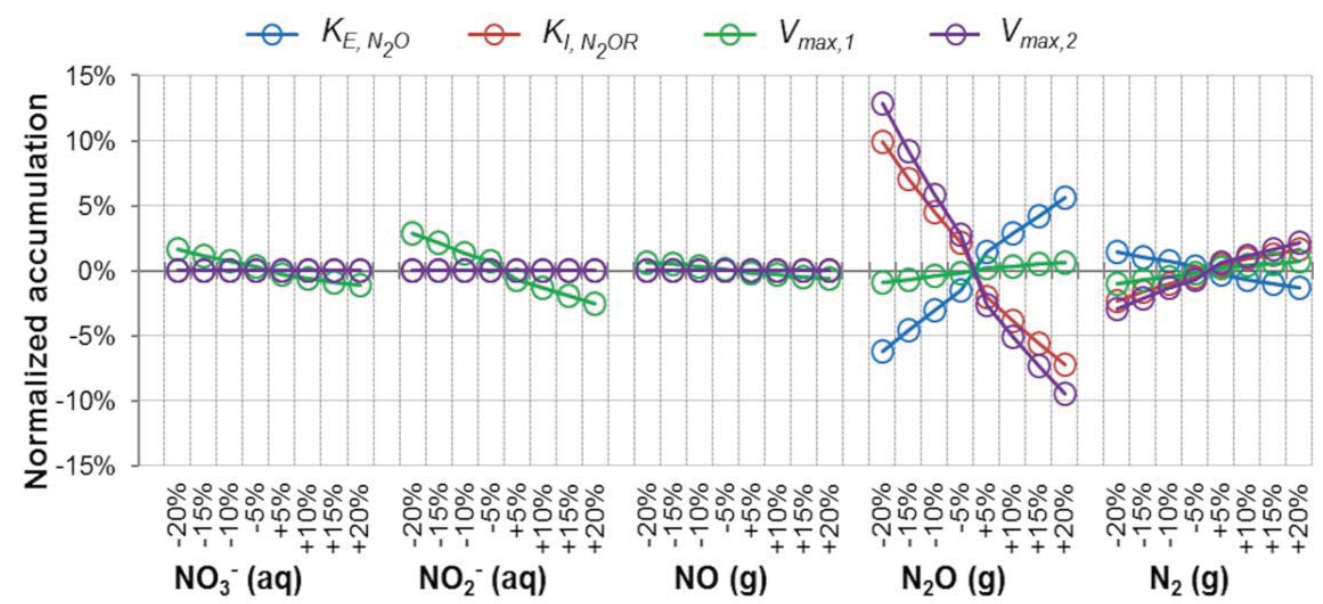

Figure 2.3 Simulated variations in the accumulation of $\mathrm{NO}_{3}^{-}, \mathrm{NO}_{2}^{-}, \mathrm{NO}, \mathrm{N}_{2} \mathrm{O}$, and $\mathrm{N}_{2}$ when variations of $\pm 5, \pm 10, \pm 15$, and $\pm 20 \%$ were applied to model parameters. 

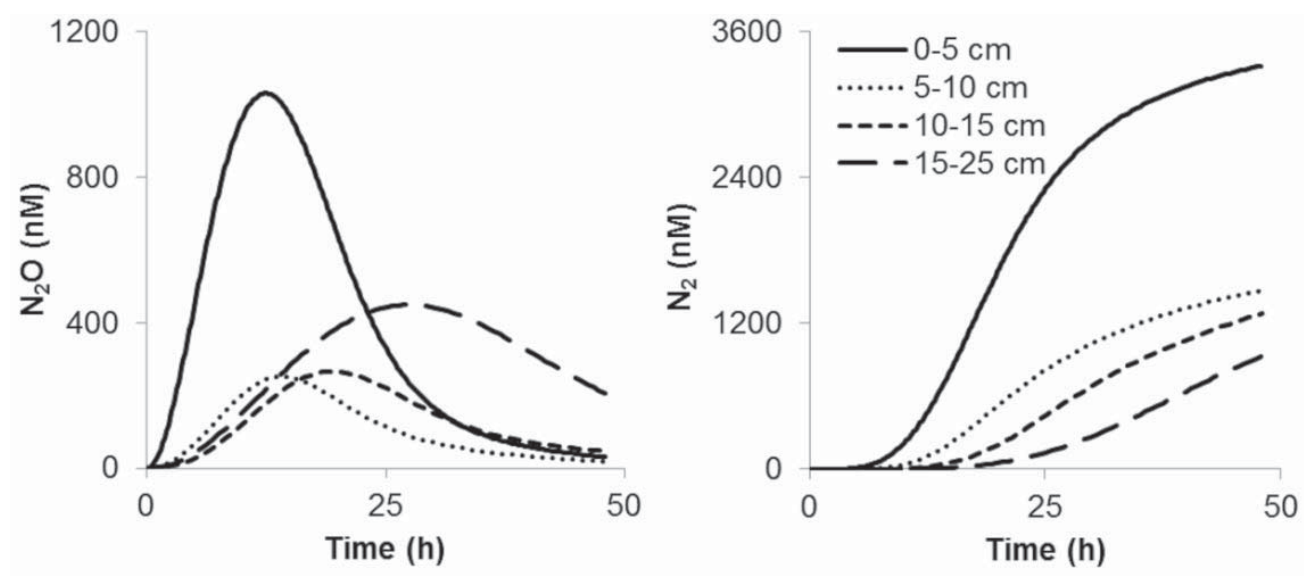

Figure 2.4 Simulations of the temporal variations of (a) $\mathrm{N}_{2} \mathrm{O}$ and (b) $\mathrm{N}_{2}$ concentrations in the helium headspace of 4 soil core sections incubated in synthetic rainwater. 


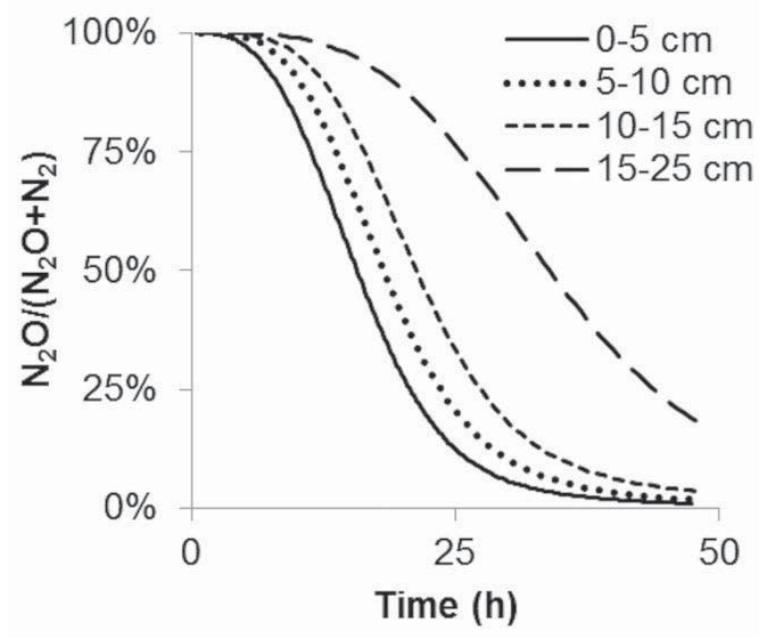

Figure 2.5 Simulations of the temporal variation of the $\mathrm{N}_{2} \mathrm{O}:\left(\mathrm{N}_{2} \mathrm{O}: \mathrm{N}_{2}\right)$ product ratio in the helium headspace of 4 soil core sections incubated in synthetic rainwater. 


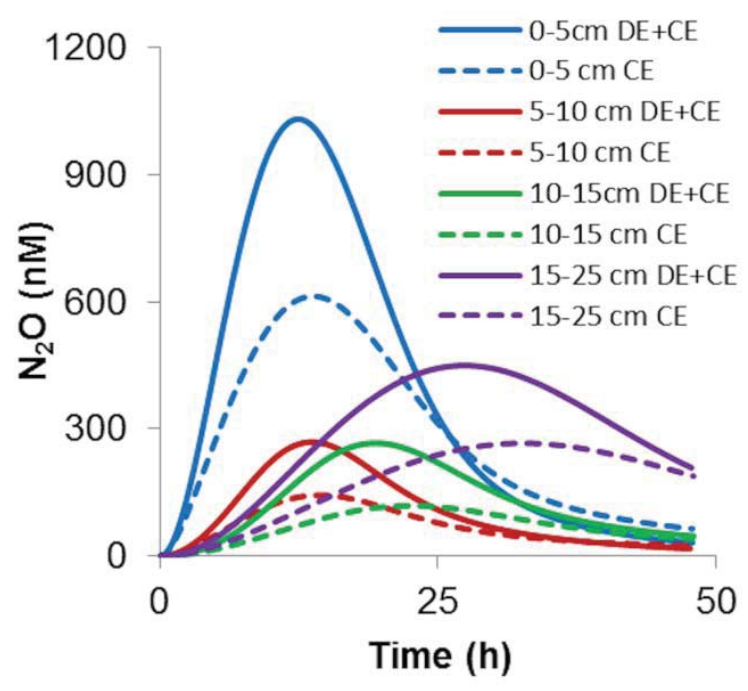

Figure 2.6 Simulations of the temporal variation of $\mathrm{N}_{2} \mathrm{O}$ in the helium headspace of 4 soil core sections incubated in synthetic rainwater with both de novo synthesized and constitutive enzymes (DE+CE) and with constitutive enzymes (CE). 


\title{
Modeling Nitrous Oxide Production and Reduction in Soil Through Explicit Representation of Denitrification Enzyme Kinetics
}

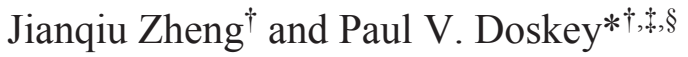 \\ ${ }^{\dagger}$ Atmospheric Sciences Program, ${ }^{\star}$ Department of Civil and Environmental Engineering, \\ ${ }^{\S}$ School of Forest Resources and Environmental Science, Michigan Technological \\ University, Houghton, Michigan 49931-1295, United States
}

\section{Supplementary Information:}

9 pages, 3 tables, 2 figures

\section{References}

Blagodatsky, S.; Grote, R.; Kiese, R.; Werner, C.; Butterbach-Bahl, K., Modelling of microbial carbon and nitrogen turnover in soil with special emphasis on $\mathrm{N}$-trace gases emission. Plant Soil 2011, 346, 297-330.

Conrad, R., Soil microorganisms as controllers of atmospheric trace gases $\left(\mathrm{H}_{2}, \mathrm{CO}\right.$, $\mathrm{CH}_{4}, \mathrm{OCS}, \mathrm{N}_{2} \mathrm{O}$, and NO). Microbiol. Rev. 1996, 60, 609-640.

Gu, C. H.; Riley, W. J., Combined effects of short term rainfall patterns and soil texture on soil nitrogen cycling - A modeling analysis. J. Contam. Hydrol. 2010, $112,141-145$.

Kampschreur, M. J.; Kleerebezem, R.; Picioreanu, C.; Bakken, L.; Bergaust, L.; de Vries, S.; Jetten, M. S.; van Loosdrecht, M. C., Metabolic modeling of denitrification 
in Agrobacterium tumefaciens: A tool to study inhibiting and activating compounds for the denitrification pathway. Front. Microbiol 2012, 3, 1-19.

Korner, H.; Zumft, W. G., Expression of denitrification enzymes in response to the dissolved oxygen level and respiratory substrate in continuous culture of Pseudomonas stutzeri. Appl Environ Microb. 1989, 55, 1670-1676.

Maggi, F.; Gu, C.; Riley, W. J.; Hornberger, G. M.; Venterea, R. T.; Xu, T.; Spycher, N.; Steefel, C.; Miller, N. L.; Oldenburg, C. M., A mechanistic treatment of the dominant soil nitrogen cycling processes: Model development, testing, and application. J. Geophys. Res. 2008, 113, doi:10.1029/2007JG000578.

Zumft, W. G., Cell biology and molecular basis of denitrification. Microbiol. Mol. Biol. R. 1997, 61, 533-616. 
Table 2.S1 Reaction kinetic parameters

\begin{tabular}{|c|c|c|c|c|}
\hline Definition & Symbol & Value & Unit & Reference \\
\hline $\begin{array}{l}\text { Aqueous phase concentration } \\
\left(i=\mathrm{O}_{2}, \mathrm{NO}_{3}^{-}, \mathrm{NO}_{2}^{-}, \mathrm{NO}, \mathrm{N}_{2} \mathrm{O}, \mathrm{N}_{2}\right. \\
\text { and } \mathrm{OC})\end{array}$ & $C_{i}$ & & & \\
\hline $\begin{array}{l}\text { Microbial biomass mediating } \\
\text { respiratory metabolism } \\
\left(i=\mathrm{O}_{2}, \mathrm{NO}_{3}^{-}, \mathrm{NO}_{2}^{-}, \mathrm{NO}, \mathrm{N}_{2} \mathrm{O}, \mathrm{N}_{2}\right)\end{array}$ & $B_{i}$ & & & \\
\hline \multicolumn{5}{|l|}{ Oxygen respiration } \\
\hline Maximum utilization rate & $\mu_{O_{2}}$ & 0.1 & $\mathrm{~h}^{-1}$ & $\mathrm{a}, \mathrm{b}, \mathrm{c}$ \\
\hline $\begin{array}{l}\text { Michaelis-Menten constant for } \mathrm{O}_{2} \\
\text { respiration }\end{array}$ & $\mathrm{KO}_{2}$ & $2.52 \times 10^{-5}$ & M & $\mathrm{b}$ \\
\hline Inhibition coefficient by NO & $K_{I, N O, O_{2}}$ & $1.74 \times 10^{-8}$ & M & c \\
\hline \multicolumn{5}{|l|}{ Nitrogen oxide reduction } \\
\hline Maximum utilization rate for nitrate & $\mu_{N O 3^{-}}$ & 0.648 & $\mathrm{~h}^{-1}$ & $\mathrm{~b}$ \\
\hline $\begin{array}{l}\text { Michaelis-Menten constant for } \\
\text { nitrate }\end{array}$ & $K_{\mathrm{NO} 3^{-}}$ & $1.3 \times 10^{-2}$ & $\mathrm{M}$ & $\mathrm{c}$ \\
\hline Maximum utilization rate for nitrite & $\mu_{\mathrm{NO} 2^{-}}^{-}$ & 0.648 & $\mathrm{~h}^{-1}$ & $\mathrm{~b}$ \\
\hline $\begin{array}{l}\text { Michaelis-Menten constant for } \\
\text { nitrite }\end{array}$ & $K_{\mathrm{NO} 2^{-}}$ & $8.8 \times 10^{-4}$ & $\mathrm{M}$ & $\mathrm{c}$ \\
\hline Maximum utilization rate for $\mathrm{NO}$ & $\mu_{N O}$ & 0.3265 & $\mathrm{~h}^{-1}$ & $\mathrm{~b}$ \\
\hline Michaelis-Menten constant for NO & $K_{N O}$ & $1.8 \times 10^{-9}$ & M & d \\
\hline Inhibition coefficient by NO & $K_{I, N O, N O}$ & $2 \times 10^{-5}$ & M & $\mathrm{c}$ \\
\hline Maximum utilization rate for $\mathrm{N}_{2} \mathrm{O}$ & $\mu_{N_{2} O}$ & 0.3247 & $\mathrm{~h}^{-1}$ & $\mathrm{~b}$ \\
\hline Michaelis-Menten constant for $\mathrm{N}_{2} \mathrm{O}$ & $\mathrm{K}_{\mathrm{N}_{2} \mathrm{O}}$ & $5 \times 10^{-6}$ & M & d \\
\hline
\end{tabular}




\begin{tabular}{lcccc}
\hline \multicolumn{1}{c}{ Definition } & Symbol & Value & Unit & Reference \\
\hline $\begin{array}{l}\text { Michaelis-Menten constant for } \\
\text { organic carbon }\end{array}$ & $K_{O C}$ & $10^{-4}$ & $\mathrm{M}$ & $\mathrm{e}$ \\
$\begin{array}{l}\text { Death rate for all microbial } \\
\text { populations }\end{array}$ & $\delta$ & 0.001 & $\mathrm{~h}^{-1}$ & $\mathrm{e}$ \\
\hline
\end{tabular}

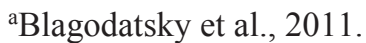

${ }^{\mathrm{b}} \mathrm{Gu}$ and Riley, 2010.

'Kampschreur et al., 2012.

dConrad, 1996.

'Maggi et al., 2008. 
Table 2.S2 Parameters for enzyme production/suppression

\begin{tabular}{ccc}
\hline Enzyme & $\begin{array}{c}\text { Half saturation } \\
\text { constant }(\mathbf{M})\end{array}$ & $\begin{array}{c}\text { O }_{2} \text { Inhibition } \\
\text { coefficient }(\mathbf{M})\end{array}$ \\
\hline NAR & $1 \times 10^{-11 \mathrm{a}, \mathrm{b}}$ & $2.5 \times 10^{-5 \mathrm{e}}$ \\
$\mathrm{NIR}$ & $5 \times 10^{-5 \mathrm{a}, \mathrm{b}, \mathrm{c}}$ & $2.2 \times 10^{-5 \mathrm{e}}$ \\
$\mathrm{NOR}$ & $5.4 \times 10^{-8 \mathrm{a}, \mathrm{b}, \mathrm{c}}$ & $4 \times 10^{-4 \mathrm{c}}$ \\
$\mathrm{N}_{2} \mathrm{OR}$ & $5 \times 10^{-7 * \mathrm{a}, \mathrm{c}, \mathrm{d}}$ & $1 \times 10^{-7 \mathrm{~d}}$ \\
\hline
\end{tabular}

aBlagodatsky et al., 2011.

${ }^{b}$ Kampschreur et al., 2012.

'Zumft 1997.

${ }^{d}$ Value estimated with the model and used in the sensitivity analysis.

eConrad 1996. 
Table 2.S3 Agreement $\left(\mathrm{R}^{2}\right)$ between model simulations and experimental data for soil core sections

\begin{tabular}{lcccc}
\hline & $\mathbf{C H L}+\mathbf{C}_{2} \mathbf{H}_{2}$ & $\mathbf{C}_{2} \mathbf{H}_{2}$ & $\mathbf{C T R}$ & $\mathbf{N}_{2}$ Production \\
\hline $0-5 \mathrm{~cm}$ & 0.99 & 0.98 & 0.97 & 0.97 \\
$5-10 \mathrm{~cm}$ & 0.97 & 0.96 & 0.90 & 0.94 \\
$10-15 \mathrm{~cm}$ & 0.98 & 0.94 & 0.85 & 0.87 \\
$15-25 \mathrm{~cm}$ & 0.98 & 0.98 & 0.97 & 0.90 \\
\hline
\end{tabular}



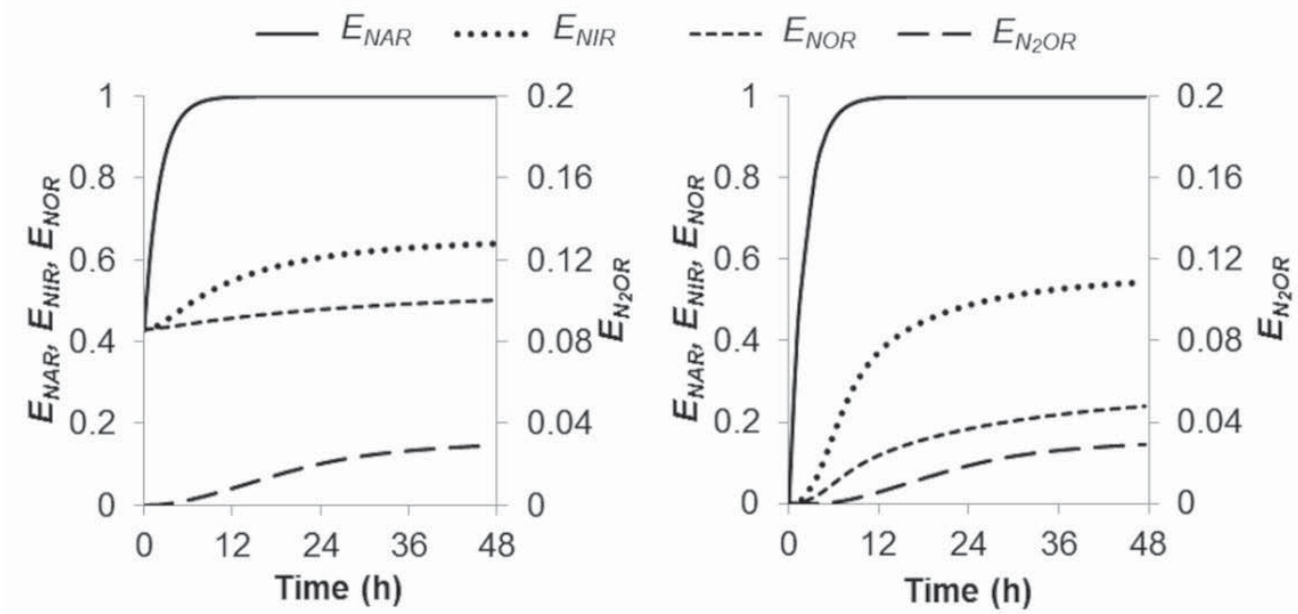

Figure 2.S1 Temporal variations of enzyme saturation factors $(E)$ for the denitrification enzymes in the $0-5 \mathrm{~cm}$ soil core section with $E_{0, N}=0.42$ and $E_{0, N}=0$ 

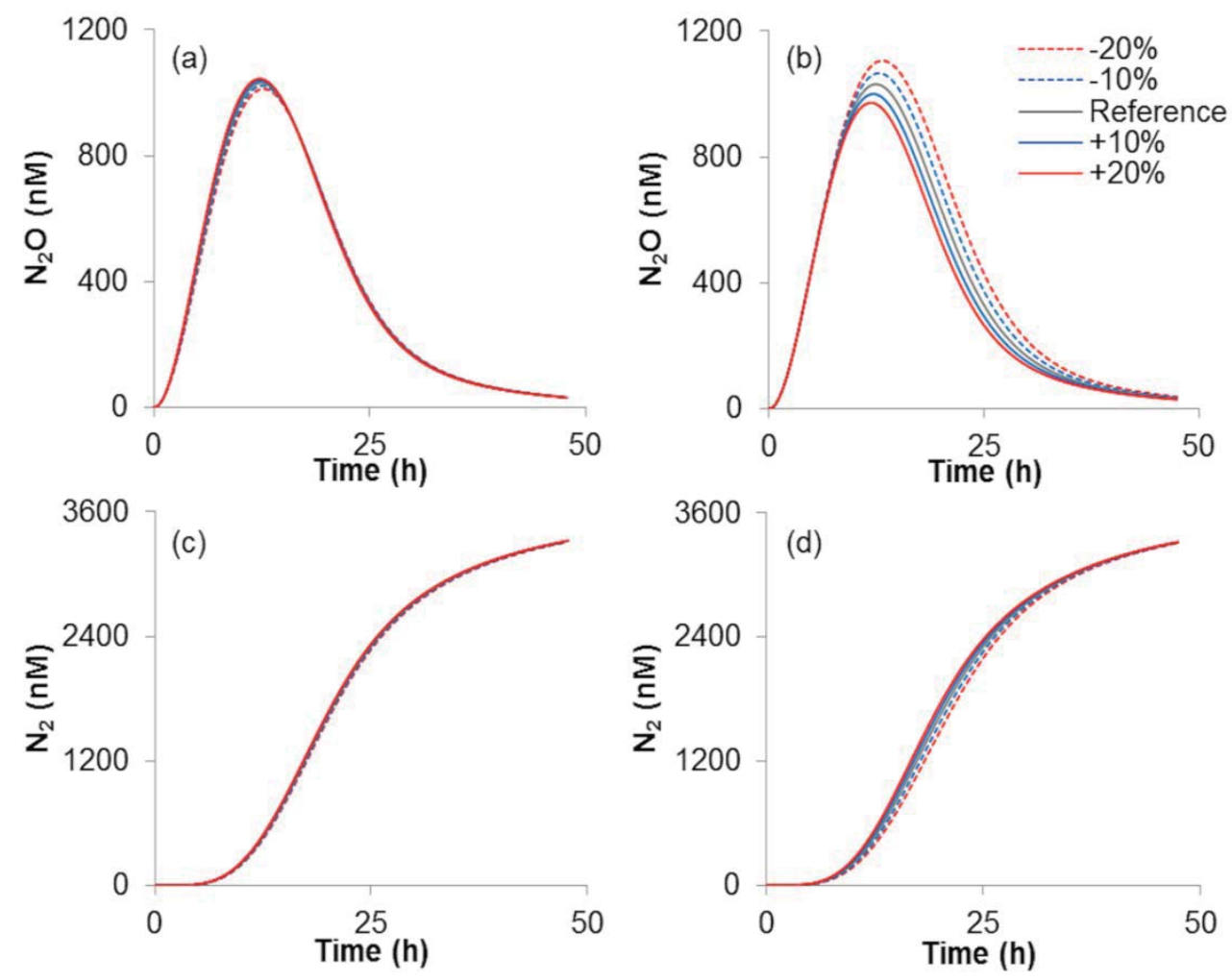

Figure 2.S2 Simulations of the temporal variations of $\mathrm{N}_{2} \mathrm{O}$ and $\mathrm{N}_{2}$ in the $0-5 \mathrm{~cm}$ soil core section with variations of \pm 10 and $\pm 20 \%$ applied to $V_{\max , 1}(\mathrm{a}, \mathrm{c})$ and $V_{\max , 2}(\mathrm{~b}, \mathrm{~d})$. 


\title{
Chapter 3
}

\section{Dynamics of Nitrous Oxide in Soil Gas and Surface Fluxes Following Simulation of Sequential Precipitation Events ${ }^{\text {II }}$}

\author{
JIANQUI ZHENG ${ }^{1}$ and PAUL V. DOSKEY $Y^{1,2,3}$ \\ ${ }^{1}$ Atmospheric Sciences Program, ${ }^{2}$ Department of Civil and Environmental \\ Engineering, and ${ }^{3}$ School of Forest Resources and Environmental Science, Michigan \\ Technological University, Houghton, MI, 49931, USA
}

Correspondence: Paul V. Doskey, tel. (906) 487-2745, fax (906) 487-2943, e-mail:pvdoskey@mtu.edu

Keywords: denitrification, $\mathrm{N}_{2} \mathrm{O}$ fluxes, precipitation, soil gas, diffusion/denitrification model

\footnotetext{
II The manuscript has been submitted to Global Change Biology
} 


\section{ABSTRACT}

Precipitation through regulation of soil microbial metabolism and soil gas movement is a major driver of soil $\mathrm{N}_{2} \mathrm{O}$ production and episodic $\mathrm{N}_{2} \mathrm{O}$ emission from the surface. Global climate models predict that the intensity and frequency of heavy precipitation events are likely to increase. We conducted comprehensive field and modeling experiments to unravel mechanisms involved in the response of soil processes to sequential precipitation events. Mixing ratios of $\mathrm{N}_{2} \mathrm{O}$ in soils gas measured at depths of 10,15 , and $25 \mathrm{~cm}$ increased rapidly from about $400 \mathrm{ppb}_{\mathrm{v}}$ to $19 \mathrm{ppm}_{\mathrm{v}}$ within $4 \mathrm{~h}$ following the first rainfall addition and stayed relatively invariant until 24-36 h following the second rainfall addition. Significant decreases in soil $\mathrm{N}_{2} \mathrm{O}$ concentrations at 10,15 , and $25 \mathrm{~cm}$ were observed after the third rainfall addition. Maxima in the surface $\mathrm{N}_{2} \mathrm{O}$ emissions were $673,168,197$, and $242 \mu \mathrm{g} \mathrm{m}^{-2} \mathrm{~h}^{-1}$ at 4 and $36 \mathrm{~h}$ following the first rainfall addition, $6-12 \mathrm{~h}$ after the second rainfall addition, and 2-6 $\mathrm{h}$ following the third rainfall addition, respectively. A diffusion-reaction model was developed to describe the $\mathrm{N}_{2} \mathrm{O}$ dynamics in soil and the resultant surface fluxes. The first and second pulses of surface $\mathrm{N}_{2} \mathrm{O}$ fluxes and rapid response of soil gas $\mathrm{N}_{2} \mathrm{O}$ following the first rainfall addition were attributed to (1) the activity of constitutive denitrification enzymes and (2) enhanced denitrification associated with microbial biomass growth, respectively. Diminished $\mathrm{N}_{2} \mathrm{O}$ emissions following the second and third simulations were likely due to enhanced $\mathrm{N}_{2} \mathrm{O}$ reduction. The 
investigation demonstrated the overwhelming importance of biological controls on surface $\mathrm{N}_{2} \mathrm{O}$ fluxes induced by precipitation. 


\section{INTRODUCTION}

Nitrous oxide $\left(\mathrm{N}_{2} \mathrm{O}\right)$ is a long-lived greenhouse gas and contributes to stratospheric ozone depletion (Ravishankara et al., 2009). Recent measurements of $\mathrm{N}_{2} \mathrm{O}$ in Antarctic ice cores suggest the atmospheric mixing ratio increased by $21 \%$ during the last 200 years (MacFarling Meure et al., 2006) and the trend is likely to continue into the future due to emissions from soil, which is the principal source of atmospheric $\mathrm{N}_{2} \mathrm{O}$ (Bouwman et al., 2013). Emissions from arable land stimulated by the application of $\mathrm{N}$ fertilizers are about 4.2 $\mathrm{Tg}^{-1}$ (IPCC, 2001) and represent more than $50 \%$ of global anthropogenic $\mathrm{N}_{2} \mathrm{O}$ sources. Modeling studies project annual $\mathrm{N}_{2} \mathrm{O}$ emissions from agricultural soils will increase to about $9.0 \mathrm{Tg}^{-1}$ by 2050 (Bouwman et al., 2013).

Emissions of $\mathrm{N}_{2} \mathrm{O}$ from soil are episodic and primarily occur as short pulses following fertilization and precipitation events (Nobre et al., 2001; Parkin \& Kaspar, 2006; Barton et al., 2008). A review of investigations of the $\mathrm{N}_{2} \mathrm{O}$ flux following rewetting of dry soils revealed that single wetting events can increase the $\mathrm{N}_{2} \mathrm{O}$ flux by $80,000 \%$ with respect to background emissions and exhalations of $\mathrm{N}_{2} \mathrm{O}$ following precipitation events contribute $2-50 \%$ of the annual $\mathrm{N}_{2} \mathrm{O}$ flux (Kim et al., 2012). Large uncertainties between measured and modeled surface fluxes have been attributed to the complexity of environmental controls on soil $\mathrm{N}_{2} \mathrm{O}$ emissions. Biogeochemical models like DAYCENT (Del Grosso et al., 2000; Del Grosso et al., 2005), DNDC (Li et al., 1992; Li et al., 1996), DAISY (Hansen et al., 1991), and 
ECOSYS (Grant \& Pattey, 2003; Metivier et al., 2009) have difficulty in reproducing the temporal profile of soil $\mathrm{N}_{2} \mathrm{O}$ emissions, which is likely due to an oversimplification of the complexities of microbial physiology and the kinetics of denitrifier enzymes and growth (Bakken et al., 2012). Understanding the belowground dynamics of $\mathrm{N}_{2} \mathrm{O}$ production, consumption, and transport to the soil surface is key to improving the prognostic ability of current models.

Production of $\mathrm{N}_{2} \mathrm{O}$ in soils is attributed to the microbial-mediated processes of nitrification and denitrification. Under aerobic conditions, autotrophic nitrifiers sequentially oxidize ammonia to nitrate $\left(\mathrm{NO}_{3}{ }^{-}\right)$and produce $\mathrm{N}_{2} \mathrm{O}$ and nitric oxide (NO) as gaseous intermediates. Denitrification proceeds when availability of molecular oxygen $\left(\mathrm{O}_{2}\right)$ is limited through sequential enzymatic reduction of $\mathrm{NO}_{3}{ }^{-}$, nitrite $\left(\mathrm{NO}_{2}^{-}\right)$, $\mathrm{NO}$, and $\mathrm{N}_{2} \mathrm{O}$ with the end product being molecular nitrogen $\left(\mathrm{N}_{2}\right)$. Denitrification is the primary process responsible for producing $\mathrm{N}_{2} \mathrm{O}$ in soils and the process is the only biological sink of $\mathrm{N}_{2} \mathrm{O}$. Reduction of $\mathrm{N}_{2} \mathrm{O}$ to $\mathrm{N}_{2}$ is catalyzed by $\mathrm{N}_{2} \mathrm{O}$ reductase $\left(\mathrm{N}_{2} \mathrm{OR}\right)$, which is more sensitive to $\mathrm{O}_{2}$ than the other 3 reductases [i.e., $\mathrm{NO}_{3}{ }^{-}, \mathrm{NO}_{2}{ }^{-}$, and $\mathrm{NO}$ reductases (NAR, NIR, and NOR, respectively)] that catalyze the denitrification process (Zumft, 1997). Transient accumulation of $\mathrm{N}_{2} \mathrm{O}$ and reduction to $\mathrm{N}_{2}$ is sensitive to fluctuation of belowground $\mathrm{O}_{2}$, which is mainly controlled by soil structure and wetting history. Studies of the complexities of denitrification have been limited to laboratory investigations conducted with pure cultures of soil denitrifiers under controlled conditions (Firestone \& Tiedje, 1979; Dendooven et al., 1994; Morley et al., 2008; Bergaust et al., 2010); however, 
process-level understanding of $\mathrm{N}_{2} \mathrm{O}$ production and consumption under field conditions is required to identify locations of elevated $\mathrm{N}_{2} \mathrm{O}$ production in soil (Butterbach-Bahl et al., 2013).

Permeability of the soil column to air is determined by physicochemical properties of the soil and water-filled pore space (WFPS), which control diffusive transport of $\mathrm{N}_{2} \mathrm{O}$ within the soil profile (Heincke \& Kaupenjohann, 1999). The dynamics of water in soil regulate transport of denitrification substrates to microbial populations, transformation of $\mathrm{N}$ species, transfer of products into soil gas, and emission from the surface. Enhanced denitrification and $\mathrm{N}_{2} \mathrm{O}$ emissions following precipitation are ascribed to increases in $\mathrm{NO}_{3}{ }^{-}$availability and reductions in $\mathrm{O}_{2}$ tension. General circulation models forecast an increasing intensity and frequency of heavy precipitation events (IPCC, 2007) that will influence $\mathrm{N}_{2} \mathrm{O}$ fluxes at the regional and global scale. Thus, field investigations of the response of soil biogeochemical processes to precipitation that include ancillary laboratory and modeling approaches are required to advance understanding of the biogeochemical regulation of $\mathrm{N}_{2} \mathrm{O}$ emissions from soil and to improve assessments of $\mathrm{N}_{2} \mathrm{O}$ inventories under future climate change scenarios.

Here, we present results of a comprehensive field study of denitrification in an agricultural soil. Sequential precipitation events were simulated and temporal variations in surface fluxes of $\mathrm{N}_{2} \mathrm{O}$, profiles of $\mathrm{N}_{2} \mathrm{O}$ levels in soil gas, and soil biogeochemical properties of the soil column were investigated. A soil gas diffusion 
model was coupled with a denitrification model that included explicit representation of enzyme kinetics (Zheng \& Doskey, 2014) to simulate the measurements.

\section{MATERIALS AND METHODS}

\section{Sampling site and rainfall simulations}

A rainfall simulation experiment was conducted on 19-24 July 2012 at the AmeriFlux site in Bondville, Illinois $\left(40^{\circ} 00^{\prime} \mathrm{N}, 88^{\circ} 18^{\prime} \mathrm{W}\right)$. Glycine $\max$ (soybean) and Zea mays (corn) have been rotated annually at the site since 2000 where no-till agriculture has been practiced for more than 20 a (Illinois Climate Network, 2012,

Bondville AmeriFlux Site, 2012). The soil type is silt loam, with an average porosity of $45 \%$ between $0-50 \mathrm{~cm}$ and an inorganic fraction composed of $25 \%$ clay, $70 \%$ silt, and 5\% sand. A continuous-spray, single-nozzle rainfall simulator was used to uniformly distribute synthetic rainwater on a $1 \mathrm{~m} \times 1 \mathrm{~m}$ plot of soybean. Synthetic rainwater was delivered from a 208-L blue plastic drum through a slotted nozzle (1/8GG-2.8W FullJet spray nozzle; Spraying Systems Co., Wheaton, IL) at 10 psig using a sump pump. The nozzle was located $157 \mathrm{~cm}$ above the surface and delivered synthetic rainwater to the plot at a rate of $22 \mathrm{~mm} \mathrm{hr}^{-1}$. Levels of minerals in the synthetic rainwater were based on the yearly average values (NADP, 2012) for the site and were $34 \mu \mathrm{M}$ ammonium, $25 \mu \mathrm{M} \mathrm{NO}_{3}^{-}, 15 \mu \mathrm{M}$ sulfate, $1.1 \mu \mathrm{M}$ phosphate, and $4 \mu \mathrm{M}$ chloride. The $\mathrm{pH}$ was adjusted to 6.6 by pumping ambient air through a diffuser into the synthetic rainwater for $12 \mathrm{~h}$. Rainfall amounts $(44 \mathrm{~mm})$ were 
delivered between 7-9 AM CST every $48 \mathrm{~h}$ to simulate 3 sequential precipitation events. Gaseous emissions from the surface, soil gas, and soil cores were collected prior to each event and at $0,2,4,6,12,24,36$, and $48 \mathrm{~h}$ after addition of the synthetic rainwater.

Sampling and analysis of surface emissions, soil gas, and soil

The static chamber technique was used to determine $\mathrm{N}_{2} \mathrm{O}$ emissions from the surface (Matthias et al., 1980; Smith et al., 1995). Chambers were constructed from 15.2-cm o.d. polyvinyl chloride (PVC) pipe and were $30 \mathrm{~cm}$ in height to maintain a geometry factor of $30 \mathrm{~cm}$ (i.e. chamber height divided by sampled surface area) to minimize disturbance of the ambient soil gas concentration profile (Matthias et al., 1978). Ambient air entered the chamber through a Teflon ${ }^{\circledR}$ capillary $(0.079-\mathrm{cm}$ i.d.) when samples were withdrawn to maintain ambient pressure in the chamber during sampling. The soil surface was covered for $1 \mathrm{~h}$ during a sampling period and chamber air was sampled at $15 \mathrm{~min}$ intervals. Samples $(12 \mathrm{~mL})$ were injected by gastight syringe (Hamilton Company, Reno, NV) into pre-evacuated $5.9 \mathrm{~mL}$ Exetainers with double-wadded caps (Labco International Inc., Houston, TX) and the puncture in the septa was sealed with silicone. Leak tests of the Exetainers indicated the vials maintained a pressure of $203 \mathrm{kPa}$ for $14 \mathrm{~d}$.

Soil gas was sampled with soil gas probes constructed from $1.25-\mathrm{cm}$ o.d. PVC pipe (Burton \& Beauchamp, 1994). Sampling wells were located at 5, 10, 15, and 25 $\mathrm{cm}$ below the soil surface and were constructed from disposable syringe barrels, which were positioned inside the probe at a $45^{\circ}$ angle to the opening to prevent water 
from entering the well. Nylon mesh glued to the opening prevented soil from entering the well during sampler placement. The wells were connected to the surface with silicone tubing $(0.079-\mathrm{cm}$ i.d.) from which $12-\mathrm{mL}$ of soil gas was sampled with a gas-tight syringe (Hamilton Company) and transferred to a $5.9 \mathrm{~mL}$ Exetainer (Labco).

Emission and soil gas samples were withdrawn from the Exetainers (Labco) into a gas-tight syringe (Hamilton Company) containing magnesium perchlorate to remove water from the sample and injected into a 1-mL stainless steel sample loop connected to a 2-position, 6-port valve (VICI, Houston, TX) upstream of a high-resolution gas chromatograph with electron capture detector (ECD; HP5890; Hewlett Packard, Palo Alto, CA). The $\mathrm{N}_{2} \mathrm{O}$ was resolved on a $30-\mathrm{m} \times 0.530-\mathrm{mm}$ fused silica capillary coated with a $3.00-\mu \mathrm{m}$ carbon film (GS-CarbonPlot; Agilent). The carrier and ECD makeup gases were $\mathrm{He}$ and $\mathrm{N}_{2}$, respectively. The measured variation of $\mathrm{N}_{2} \mathrm{O}$ was less than $2 \%$ at the quantitative detection limit $\left(<5 \mathrm{ppb}_{\mathrm{v}}\right)$.

A 1.27-cm o.d. stainless steel sampler (AMS, Inc. American Falls, ID) was used to sample soil to a depth of $25 \mathrm{~cm}$. Soil cores were sectioned at $0-5,5-10,10-15$, and $15-25 \mathrm{~cm}$ increments, transferred to $15-\mathrm{mL}$ sterile plastic tubes (Fisher Scientific, Pittsburgh, PA), immediately stored in liquid $\mathrm{N}_{2}$, and transported to the laboratory in a liquid $\mathrm{N}_{2}$ dewar (PrincetonCryo, Flemington, NJ). Subsamples were sieved (4-mm) prior to analysis of $\mathrm{pH}$, water-filled pore space (WFPS), $\mathrm{NO}_{3}{ }^{-}$, and extractable organic and microbial biomass carbon (EOC and SMBC, respectively). Levels of EOC and $\mathrm{NO}_{3}{ }^{-}$in soils were determined in potassium sulfate extracts of soil via 
analysis with a TOC Analyzer (Sievers 900, GE Analytical Instruments, CO) and Rapid Flow Analyzer (Perstorp Analytical Inc., Silver Spring, MD), respectively.

\section{Coupled soil gas diffusion/denitrification model}

Equilibrium conditions were assumed for gas exchange between aqueous- and gas-filled pore space during simulation of the 3 sequential rainfall events and fluxes of $\mathrm{N}_{2} \mathrm{O}$ from the soil surface were estimated from profiles of soil gas concentrations. The one-dimensional vertical flow of gases in the soil column was assumed to obey Fick's Law as follows:

$$
q=-D_{e} \frac{d C}{d z}
$$

where $q$ is the gas flux $\left(\mathrm{g} \mathrm{cm}^{-2} \mathrm{~s}^{-1}\right), D_{e}$ is the effective gas diffusion coefficient in soil $\left(\mathrm{cm}^{2} \mathrm{~s}^{-1}\right), \mathrm{C}$ is the gas concentration $\left(\mathrm{g} \mathrm{cm}^{-3}\right.$ air), and $z$ is the soil depth $(\mathrm{cm})$. The value of $D_{e}$ can be estimated as the product of the gas diffusion coefficient in air $\left(D_{0}\right)$ and the empirical function of air-filled porosity $\left(\theta_{a}\right)$ and total porosity $\left(\theta_{r}\right)$. Values of the relative soil gas diffusivity $\left(D_{e} / D_{0}\right)$ were estimated using several empirical models (Table 3.1) and were different; however, the values were well correlated with one another $\left(\mathrm{R}^{2}>0.99\right)$. The sequence of 3 rainfall simulations within a period of $6 \mathrm{~d}$ prevented rapid changes in soil air-filled porosity and the intensive sampling schedule limited variations in soil structure within the plot. Thus, estimates of $\left(D_{e} / D_{0}\right)$ based on empirical models are suitable for modeling soil gas diffusion at the plot scale for the experimental conditions. 
Assuming instantaneous equilibrium between gas- and liquid-phase concentrations of $\mathrm{N}_{2} \mathrm{O}$ throughout the soil column, the following mass balance is obtained:

$$
\left(\theta_{a}+\theta_{w} \cdot H\right) \frac{\partial C}{\partial t}=\frac{\partial}{\partial z}\left(D_{e} \frac{\partial C}{\partial z}\right)+p-r
$$

where $C$ is the gas-phase concentration of $\mathrm{N}_{2} \mathrm{O}$ in the soil, $\theta_{w}$ is water-filled porosity (i.e., volumetric water content), $H$ is Henry's law constant for $\mathrm{N}_{2} \mathrm{O}$ ( vol $_{\text {air }}$ voll $^{-1}$ water), and $\left(\theta_{a}+\theta_{w} H\right) C$ represents the sum of gas- and liquid-phase concentrations of $\mathrm{N}_{2} \mathrm{O}$ (Stolk et al., 2011). Gross rates of production and reduction of $\mathrm{N}_{2} \mathrm{O}$ in soil are estimated using Michaelis-Menten kinetics as follows:

$$
\begin{gathered}
p=\left(\frac{V_{\max }^{\mathrm{NO}_{3}^{-}}\left[\mathrm{NO}_{3}^{-}\right]}{K_{m}^{N O_{3}^{-}}+\left[N O_{3}^{-}\right]}\right)\left(\frac{[E O C]}{K_{m}^{C}+[E O C]}\right) \\
r=\left(\frac{V_{\max }^{\mathrm{N}_{2} \mathrm{O}} \cdot H \cdot\left[\mathrm{N}_{2} \mathrm{O}\right]}{K_{m}^{\mathrm{N}_{2} \mathrm{O}}+H \cdot\left[\mathrm{N}_{2} \mathrm{O}\right]}\right)\left(\frac{[E O C]}{K_{m}^{C}+[E O C]}\right)
\end{gathered}
$$

where $p$ and $r$ are the rates of $\mathrm{N}_{2} \mathrm{O}$ production and reduction $\left(\mathrm{ng} \mathrm{cm}^{-3} \mathrm{~s}^{-1}\right)$, respectively, $V_{\max }^{\mathrm{NO}_{3}^{-}}$and $V_{\max }^{\mathrm{N}_{2} \mathrm{O}}$ are the maximum rate of $\mathrm{N}_{2} \mathrm{O}$ production and reduction, respectively, and $K_{m}^{\mathrm{NO}_{3}^{-}}, K_{m}^{\mathrm{N}_{2} \mathrm{O}}$, and $K_{m}^{\mathrm{C}}$ are Michaelis-Menten constants for $\mathrm{NO}_{3}^{-}$, $\mathrm{N}_{2} \mathrm{O}$, and EOC, respectively. Reported values of $K_{m}^{C}$ span a wide range (0.37-13.6 $\mu \mathrm{g} \mathrm{g}^{-1}$; Maggi et al., 2008). However, levels of EOC were significantly greater than the reported values, and thus, Eqn. (3) and (4) reduce to the following: 


$$
\begin{gathered}
p=\frac{V_{\max }^{N O_{3}^{-}}\left[N O_{3}^{-}\right]}{K_{m}^{N O_{3}^{-}}+\left[N O_{3}^{-}\right]} \\
r=\frac{V_{\max }^{N_{2} O} \cdot H \cdot\left[N_{2} O\right]}{K_{m}^{N_{2} O}+H \cdot\left[N_{2} O\right]}
\end{gathered}
$$

Effects of independent variables of the study, i.e., rainwater addition and sampling time and depth on soil $\mathrm{NO}_{3}{ }^{-}, \mathrm{EOC}$, and WFPS were analyzed with statistical packages in R (R Core Team, 2013). A one-way ANOVA and Tukey's test were performed to detect differences related to independent variables with the level of significance specified as $\mathrm{p}<0.05$. The numerical solution of the diffusion/denitrification model was obtained with the finite difference algorithm in Matlab (The Mathworks, Inc., Natick, MA, USA) with a time step of $1 \mathrm{~s}$. A scheme for the coupled soil gas diffusion/denitrification model can be found in Fig. 3.1. Initial conditions were based on measurements obtained at $0 \mathrm{~h}$ following the first rainfall simulation and boundary conditions were set to match the $\mathrm{N}_{2} \mathrm{O}$ dynamics measured at $25 \mathrm{~cm}$ below the surface.

\section{RESULTS}

Measurements of environmental variables

Concentrations of $\mathrm{NO}_{3}{ }^{-}$within each layer of soil were highly dynamic during the measurement period (Fig. 3.2a). Rapid increases in $\mathrm{NO}_{3}{ }^{-}$levels were observed immediately after the rainfall addition at each depth; however, concentrations became less variable after $2 \mathrm{~h}$. Variations in soil $\mathrm{NO}_{3}{ }^{-}$concentrations within the first 
$6 \mathrm{~h}$ after rainfall addition were attributed to the high mobility of $\mathrm{NO}_{3}{ }^{-}$in soil, rapid movement with water, and uptake by plant roots. Concentrations of $\mathrm{NO}_{3}{ }^{-}$at 15 and $25 \mathrm{~cm}$ were significantly greater $(\mathrm{p}<0.05$ and $\mathrm{p}<0.001$, respectively) than the levels at 5 and $10 \mathrm{~cm}$. Response patterns of soil $\mathrm{NO}_{3}{ }^{-}$to rainwater addition across different depths were similar for the 3 rainfall additions and the $\mathrm{NO}_{3}{ }^{-}$input from the second and the third rainfall additions did not increase soil $\mathrm{NO}_{3}{ }^{-}$concentrations significantly.

Concentrations of EOC exhibited a rapid increase within the first $6 \mathrm{~h}$ following the rainfall additions (Fig. 3.2b) due to the rapid movement of water. Soil rewetting from the second and third rainfall additions significantly increased soil EOC ( $\mathrm{p}<$ 0.001 and $p=0.003$, respectively), which might be attributed to enhanced microbial growth or release of carbon due to disruption of the soil structure (Lundquist et al., 1999). Soil EOC appeared to be highest in the $0-5 \mathrm{~cm}$ layer and gradually decreased with soil depth. Higher levels of EOC in the surface layer might be attributed to inputs from plant litter, root exudates, and microbial biomass.

The WFPS increased dramatically after the first rainfall addition and remained $>$ $50 \%$ during the entire measurement period (Fig. 3.3). For all three rainfall simulations, WFPS reached the highest level at $4 \mathrm{~h}(\mathrm{p}<0.001, \mathrm{p}<0.05$, and $\mathrm{p}=0.14$, respectively) and then decreased to the lowest point at 36 or $48 \mathrm{~h}$ after the rainfall additions ( $\mathrm{p}<0.001, \mathrm{p}<0.05$, and $\mathrm{p}=0.157$, respectively) as the soil dried. 
Differences in WFPS between soil depths were most distinct following the third rainfall addition.

Dynamics of $\mathrm{N}_{2} \mathrm{O}$ in soil gas

Mixing ratios of $\mathrm{N}_{2} \mathrm{O}$ in soil gas of the soil column before the first rainfall addition (Fig. 3.4) were slightly higher than the ambient level (320 ppb $)$ and exhibited a unique two-peak pattern after the first rainfall addition. The first peak was most pronounced at $5 \mathrm{~cm}, 4 \mathrm{~h}$ after the first rainfall addition and the second peak occurred at 24-36 $\mathrm{h}$ at the 10,15 , and $25 \mathrm{~cm}$ depths. Mixing ratios diminished to a minimum at $6 \mathrm{~h}$ at 10,15 , and $25 \mathrm{~cm}$ below the soil surface. There was a dramatic increase from ambient levels to $7-14 \mathrm{ppm}_{\mathrm{v}}$ within $2 \mathrm{~h}$ at 15 and $25 \mathrm{~cm}$ below the surface within $2 \mathrm{~h}$ of the first rainfall addition. Increases in $\mathrm{N}_{2} \mathrm{O}$ mixing ratios at 5 and $10 \mathrm{~cm}$ lagged the increase in deeper layers, which was attributed to upward diffusion from deep layers to the surface. Levels increased to about $10 \mathrm{ppm}_{\mathrm{v}}$ within 4 $\mathrm{h}$ of the second and third rainfall additions. The highest mixing ratios were observed at $40-60 \mathrm{~h}$ at a depth of $25 \mathrm{~cm}$ during the second rainfall addition with levels diminishing after $80 \mathrm{~h}$. During the third rainfall addition at $98-100 \mathrm{~h}$, the decrease in mixing ratios of $\mathrm{N}_{2} \mathrm{O}$ was accelerated; however, an increase in levels was observed 4-6 $\mathrm{h}$ after the third rainfall addition.

Measured surface emissions and simulated diffusive fluxes 
The temporal profile of $\mathrm{N}_{2} \mathrm{O}$ emissions from the surface exhibited uptake of $\mathrm{N}_{2} \mathrm{O}$ before and $0 \mathrm{~h}$ after the first rainfall addition (Fig. 3.5). With the exception of an emission maxima $4 \mathrm{~h}$ after the first rainfall addition, fluxes from the surface were 166-242 $\mu \mathrm{g} \mathrm{m}^{-2} \mathrm{~h}^{-1}$ during the remainder of the experiment (Fig. 3.5). Maxima in $\mathrm{N}_{2} \mathrm{O}$ emissions occurred between 2-6 and $36 \mathrm{~h}$ following the first rainfall addition, $6-$ $12 \mathrm{~h}$ after the second rainfall addition, and 2-6 $\mathrm{h}$ following the third rainfall addition $(\mathrm{p}<0.05)$. The largest flux $\left(673 \mu \mathrm{g} \mathrm{m}^{-2} \mathrm{~h}^{-1}\right)$ was observed $4 \mathrm{~h}$ after the first rainfall addition concomitant with a peak in the mixing ratio of $\mathrm{N}_{2} \mathrm{O}$ in soil gas ( $\left.3 \mathrm{ppm}_{\mathrm{v}}\right)$ at a depth of $5 \mathrm{~cm}$ (Fig. 3.4).

Temporal variations in the diffusive flux of $\mathrm{N}_{2} \mathrm{O}$ from soil gas at a depth of $5 \mathrm{~cm}$ were simulated with Eqn. (1) and followed the same dynamics as the surface fluxes (Fig. 3.6). However, diffusive fluxes simulated for deeper layers exhibited distinct dynamics, which might be explained by shorter time scales for microbial sources and sinks of $\mathrm{N}_{2} \mathrm{O}$ in deeper layers of soil relative to the time scale of diffusion. The simulated diffusive flux decreased with soil depth between $2-12 \mathrm{~h}$ after the first rainfall addition, which is strong evidence of $\mathrm{N}_{2} \mathrm{O}$ production in deep layers of the soil. In contrast, simulated diffusive fluxes from deeper layers after $12 \mathrm{~h}$ following the first rainfall addition were higher than the flux from $5 \mathrm{~cm}$ and suggest enhanced reduction of $\mathrm{N}_{2} \mathrm{O}$ below $5 \mathrm{~cm}$ (Fig. 3.6). Simulated diffusive fluxes from layers below $5 \mathrm{~cm}$ following the second and third rainfall simulations were always higher than the flux from $5 \mathrm{~cm}$, indicating substantial $\mathrm{N}_{2} \mathrm{O}$ reduction below $5 \mathrm{~cm}$. 
Simulation of soil $\mathrm{N}_{2} \mathrm{O}$ behavior

The coupled soil gas diffusion/dentrification model was used to simulate temporal variations in the accumulation of $\mathrm{N}_{2} \mathrm{O}$ with depth in the soil column after the first rainfall addition. Estimates of $V_{\max }^{\mathrm{NO}_{3}^{-}}$and $V_{\max }^{\mathrm{N}_{2} \mathrm{O}}$ in Eqn (5) and (6) were based on the model simulations of the gas dynamics from incubated soil cores obtained before the first simulated rainfall (Zheng \& Doskey, 2014). The measured WFPS was between $50-80 \%$ during the experiment, resulting in ideal $\mathrm{O}_{2}$ tensions for denitrification (Linn \& Doran, 1984; Davidson et al., 2000). Estimates of gas phase $\mathrm{O}_{2}$ concentrations from measurements of WFPS were between 2-5\%, which would not inhibit the synthesis of NAR, NIR, and NOR given their high $\mathrm{O}_{2}$ inhibition coefficients (Zheng \& Doskey, 2014). Given that measured $\mathrm{NO}_{3}{ }^{-}$concentrations were much less than $K_{m}^{N O_{3}^{-}}, p$ was directly proportional to the $\mathrm{NO}_{3}{ }^{-}$concentration. Concentrations of $\mathrm{NO}_{3}{ }^{-}$showed significant variations between depths (Fig. 3.2a); however, levels were quite consistent within soil layers. Precision for the $\mathrm{NO}_{3}{ }^{-}$ measurements were poor, making variations in $\mathrm{NO}_{3}{ }^{-}$concentrations difficult to determine. Thus, average values of $\mathrm{NO}_{3}{ }^{-}$concentrations in the model were applied for each depth and $p$ was approximately a constant. Values of $p$ and $V_{\max }^{\mathrm{N}_{2} \mathrm{O}}$ were estimated with the metabolic denitrification model, which was developed from a laboratory incubation study of soil cores sampled before the rainfall simulation experiment (Zheng \& Doskey, 2014). Rapid $\mathrm{O}_{2}$ depletion in the anaerobic incubation 
system was adjusted to fit the conditions of the field experiment to estimate values of $p$ and $V_{\max }^{N_{2} O}$ for the sequential rainfall simulations (Table 3.2).

The coupled soil gas diffusion/dentrification model was used to simulate temporal variations in the accumulation of $\mathrm{N}_{2} \mathrm{O}$ with depth in the soil column after the first rainfall addition, which exhibited the most dynamic variations of the 3 rainfall additions (Fig. 3.7a). The model simulation suggests that much of the $\mathrm{N}_{2} \mathrm{O}$ is reduced during transport to the surface. The estimated value of $D_{e}$ was smallest for the 5-10 cm layer of soil, and thus, the residence time of $\mathrm{N}_{2} \mathrm{O}$ in the layer was greatest, which increased the extent of $\mathrm{N}_{2} \mathrm{O}$ reduction. However, production of $\mathrm{N}_{2} \mathrm{O}$ was nearly constant during the $48 \mathrm{~h}$ following the first rainfall addition.

Accumulation of $\mathrm{N}_{2} \mathrm{O}$ in soil gas during the $6 \mathrm{~h}$ after the first rainfall addition was grossly underestimated. Incubations of soil cores collected prior to the first rainfall addition indicated that constitutive denitrification enzymes (i.e., defined here as pre-synthesized or constitutively synthesized denitrification proteome) were responsible for $\mathrm{N}_{2} \mathrm{O}$ production via $\mathrm{NO}_{3}{ }^{-}$reduction during the first $6 \mathrm{~h}$ after the onset of anaerobiosis (Zheng \& Doskey, 2014). Simulations with the coupled model that included an $\mathrm{N}_{2} \mathrm{O}$ production term for constitutive denitrification enzymes exhibited a peak in the accumulation of $\mathrm{N}_{2} \mathrm{O}$ in soil gas at $4 \mathrm{~h}$ and were in better agreement with the measurements (Fig. 3.7b).

\section{DISCUSSION}


The most dramatic increase in mixing ratios of $\mathrm{N}_{2} \mathrm{O}$ in soil gas (Fig. 3.4) were observed during the first rainfall simulation when WFPS increased from $30 \%$ to $70 \%$ (Fig. 3.3) concomitant with the transition from aerobic to anaerobic conditions in the soil column. The WFPS of the $0-5 \mathrm{~cm}$ layer of soil increased to $73 \%$ within $2 \mathrm{~h}$ after the rainfall was added to the plot and was $70 \%$ at a depth of $15-25 \mathrm{~cm} 4 \mathrm{~h}$ after the rainfall addition. Due to rapid infiltration of water into the soil column, $\mathrm{O}_{2}$ diffusion from the atmosphere is diminished and there is a rapid transition from aerobic to anaerobic conditions that allow denitrification to proceed. Infiltration of $\mathrm{NO}_{3}{ }^{-}$ provided substrate to the deeper soil layers (Fig. 3.2) and accelerated $\mathrm{N}_{2} \mathrm{O}$ production. Increases in the mixing ratios of $\mathrm{N}_{2} \mathrm{O}$ in soil gas of the upper soil layers $(0-10 \mathrm{~cm})$ occurred $2 \mathrm{~h}$ later than the deeper soil layers $(10-25 \mathrm{~cm})$. The highest WFPS levels were observed at 2-4 h between depths of 5-15 cm (Fig. 3.3), which limited gaseous diffusion of $\mathrm{N}_{2} \mathrm{O}$ to the surface layer of soil. The second and third rainfall additions induced much smaller increases in the mixing ratios of $\mathrm{N}_{2} \mathrm{O}$ in soil gas. After the first rainfall addition, the WFPS is likely saturated with $\mathrm{N}_{2} \mathrm{O}$ due to the high solubility in water, which might buffer the denitrification process and prevent increases in $\mathrm{N}_{2} \mathrm{O}$ mixing ratios in soil gas (Heincke \& Kaupenjohann, 1999). Increases in WFPS soon after the second and third rainfall additions might have promoted reduction of $\mathrm{N}_{2} \mathrm{O}$ to $\mathrm{N}_{2}$ and might explain the decrease in mixing ratios of $\mathrm{N}_{2} \mathrm{O}$ in soil gas relative to the first rainfall addition (Fig. 3.4).

Surface fluxes of $\mathrm{N}_{2} \mathrm{O}$ throughout the experiment were adequately explained by the diffusive flux in soil gas that was driven by the gradient in $\mathrm{N}_{2} \mathrm{O}$ mixing ratios 
between a depth of $5 \mathrm{~cm}$ and the surface (Fig. 3.5). Yoh et al. (1997) also observed a correlation between measured surface fluxes and estimated diffusive losses from soil. Analysis of the soil gas diffusion process with ${ }^{15} \mathrm{~N}$-labelled $\mathrm{N}_{2} \mathrm{O}$ showed (1) the estimated diffusive flux from a depth of $5 \mathrm{~cm}$ exhibited the best correlation with the measured surface flux of $\mathrm{N}_{2} \mathrm{O}$ and (2) estimated diffusive fluxes from depths of 15, 30 , and $45 \mathrm{~cm}$ in the soil were greater than the estimated diffusive flux from a depth of $5 \mathrm{~cm}$ (Clough et al., 2006). Results from the first rainfall addition suggest enhanced reduction of $\mathrm{N}_{2} \mathrm{O}$ below $5 \mathrm{~cm}$, which agrees with Hosen et al. (2000) who concluded that a reduction in productivity of $\mathrm{N}_{2} \mathrm{O}$ could not be explained without invoking an $\mathrm{N}_{2} \mathrm{O}$ sink to interpret the pattern of observed soil $\mathrm{N}_{2} \mathrm{O}$ dynamics. Temporal variations of the estimated diffusive flux from different soil depths were distinct (Fig. 3.6), which suggested production and reduction of $\mathrm{N}_{2} \mathrm{O}$ affected mixing ratios in soil.

Production of $\mathrm{N}_{2} \mathrm{O}$ in soil after the first rainfall addition appeared to occur in 2 distinct phases, which is in agreement with soil incubation studies (Firestone \& Tiedje, 1979; Dendooven \& Anderson, 1995). Rapid $\mathrm{N}_{2} \mathrm{O}$ production in the first phase was due to the activity of constitutive enzymes, which were composed of NAR, NIR, and NOR. Nitrous oxide reductase $\left(\mathrm{N}_{2} \mathrm{OR}\right)$ does not persist in dry soil due to an extreme sensitivity to $\mathrm{O}_{2}$, and thus, $\mathrm{N}_{2} \mathrm{O}$ is not reduced in the first phase, which leads to a rapid accumulation of $\mathrm{N}_{2} \mathrm{O}$. Delayed synthesis of $\mathrm{N}_{2} \mathrm{OR}$ led to rapid accumulation of $\mathrm{N}_{2} \mathrm{O}$ during early stages of the incubations of soil cores collected prior to the first rainfall addition (Zheng \& Doskey, 2014), which corresponded with 
the dynamics observed in the field. The accumulation of $\mathrm{N}_{2} \mathrm{O}$ in the second phase was due to $\mathrm{N}_{2} \mathrm{O}$ production and reduction associated with biomass growth. The coupled model accurately simulated the dynamics of $\mathrm{N}_{2} \mathrm{O}$ accumulation during the first phase of denitrification by including representation of $\mathrm{N}_{2} \mathrm{O}$ production by constitutive denitrification enzymes. Simulations of the second phase that included representations of $\mathrm{N}_{2} \mathrm{O}$ production/reduction associated with biomass growth showed good agreement with the field measurements. The estimated $\mathrm{N}_{2} \mathrm{O}$ reduction rate was 4-10 times greater than the rate of $\mathrm{N}_{2} \mathrm{O}$ diffusion in soil gas, which is in agreement with other studies (Firestone \& Davidson, 1989) and explains the decrease in the surface flux of $\mathrm{N}_{2} \mathrm{O}$ at $12 \mathrm{~h}$ following the first rainfall addition.

Constitutive enzymes also influenced the accumulation of $\mathrm{N}_{2} \mathrm{O}$ during the second and third rainfall simulations. Synthesis of $\mathrm{N}_{2} \mathrm{OR}$ occurred during the first rainfall simulation, and thus, lags between the synthesis of $\mathrm{N}_{2} \mathrm{OR}$ and NAR, NIR, and NOR were not observed during the second and third rainfall simulations. Dramatic increases in soil WFPS were observed within 4 hours following the second and third rainfall additions that reduced $\mathrm{O}_{2}$ tension. The pool size of $\mathrm{N}_{2} \mathrm{OR}$ expanded as $\mathrm{N}_{2} \mathrm{OR}$ could be synthesized under optimal WFPS during the first few hours following each rainfall addition. The active $\mathrm{N}_{2} \mathrm{OR}$ enzyme pool insured $\mathrm{N}_{2} \mathrm{O}$ reduction under suboptimal WFPS in which de novo synthesis of $\mathrm{N}_{2} \mathrm{OR}$ was severely inhibited. The hypothesis was tested in model simulations using the metabolic denitrification model by doubling and tripling the pool size of $\mathrm{N}_{2} \mathrm{OR}$ (Fig. 3.8). Accumulation of $\mathrm{N}_{2} \mathrm{O}$ was significantly diminished with an elevated pool size of 
$\mathrm{N}_{2} \mathrm{OR}$ under the same $\mathrm{O}_{2}$ tension $(2 \% \mathrm{v} / \mathrm{v})$. Soil core incubations also demonstrated a significant increase in the potential of the composite denitrifiers to reduce $\mathrm{N}_{2} \mathrm{O}$ following the second and third rainfall additions (Zheng \& Doskey, 2014). The $\mathrm{N}_{2} \mathrm{O}$ reduction potential can be evaluated as the ratio of $\mathrm{N}_{2} \mathrm{O}$ reduction rate to the denitrification rate, which was 0.31 over a $48 \mathrm{hr}$ incubation study of the soil cores sampled before the first rainfall addition. The $\mathrm{N}_{2} \mathrm{O}$ reduction potential increased to 0.72 and 0.93 during the second and third rainfall additions, respectively.

Measuring temporal variations in the profile of mixing ratios of $\mathrm{N}_{2} \mathrm{O}$ in soil gas, microbial substrates, and surface fluxes that are induced by precipitation is a transformative approach for investigating soil biogeochemical controls on emissions of $\mathrm{N}_{2} \mathrm{O}$. Biological controls of $\mathrm{N}_{2} \mathrm{O}$ production overwhelmed physical controls of $\mathrm{N}_{2} \mathrm{O}$ movement within soil gas when optimal conditions for denitrification existed in the soil microenvironment. Traditional environmental indicators of $\mathrm{N}_{2} \mathrm{O}$ production like WFPS had limited ability to predict surface fluxes of $\mathrm{N}_{2} \mathrm{O}$. The critical role of constitutive denitrifiers to surface fluxes during the rapid transition from aerobic to anaerobic conditions was demonstrated by simulating sequential rainfall events. The estimated contribution of constitutive denitrifiers was $>40 \%$ during the first $24 \mathrm{~h}$ after the first rainfall addition; however, the contribution is relative to the time span selected to calculate cumulative fluxes. Future climate change scenarios suggest extreme precipitation events ( $\sim 80 \mathrm{~mm}$ in $48 \mathrm{~h}$ ) will increase in frequency and intensity, and thus, results from the simulation of sequential rainfall events are useful for predicting effects on $\mathrm{N}_{2} \mathrm{O}$ emissions from soil. However, prolonged waterlogging 
of soils might increase with the frequency and intensity of precipitation, lower the $\mathrm{N}_{2} \mathrm{O}: \mathrm{N}_{2}$ product ratios of denitrification, and decrease $\mathrm{N}_{2} \mathrm{O}$ emissions from soil. Comprehensive field investigations of denitrification that examine the kinetics of soil biogeochemical processes like the study described here will be useful in predicting $\mathrm{N}_{2} \mathrm{O}$ emissions under various land use-use and land management practices and future climate-change scenarios.

\section{ACKNOWLEDGEMENTS}

The authors acknowledge start-up funding, which supported Jianqiu Zheng, and an equipment loan to Paul V. Doskey through Michigan Technological University and Argonne National Laboratory, respectively. Partial support for Jianqiu Zheng through the Atmospheric Sciences Program is also greatly appreciated. The authors thank Mr. Robert Fritz for fabricating the rainfall simulator and soil gas sampling probe and Keenan A. Murray for assistance with field sampling.

\section{REFERENCES}

Bakken LR, Bergaust L, Liu B, Frostegård Å (2012) Regulation of denitrification at the cellular level: A clue to the understanding of $\mathrm{N}_{2} \mathrm{O}$ emissions from soils. Philosophical Transactions of the Royal Society of London Series B: Biological Sciences, 367, 1226-1234. 
Bartelt-Hunt SL, Smith JA (2002) Measurement of effective air diffusion coefficients for trichloroethene in undisturbed soil cores. Journal of Contaminant Hydrololgy, 56, 193-208.

Barton L, Kiese R, Gatter D, Butterbach-Bahl K, Buck R, Hinz C, Murphy DV (2008) Nitrous oxide emissions from a cropped soil in a semi-arid climate. Global Change Biology, 14, 177-192.

Bergaust L, Mao Y, Bakken LR, Frostegård Å (2010) Denitrification response patterns during the transition to anoxic respiration and posttranscriptional effects of suboptimal $\mathrm{pH}$ on nitrogen oxide reductase in Paracoccus denitrificans. Applied and Environmental Microbiology, 76, 6387-6396.

Bondville AmeriFlux Site (2012) AmeriFlux US-Bo1 sponsored by NOAA/GEWEX http://ameriflux.ornl.gov/fullsiteinfo.php?sid=44.

Bouwman AF, Beusen AH, Griffioen J et al. (2013) Global trends and uncertainties in terrestrial denitrification and $\mathrm{N}_{2} \mathrm{O}$ emissions. Philosophical Transactions of the Royal Society of London Series B: Biological Sciences, 368, doi: 10.1098/rstb.2013.0112. 
Burton DL, Beauchamp EG (1994) Profile nitrous oxide and carbon dioxide concentrations in a soil subject to freezing. Soil Science Society of America Journal, 58, 115-122.

Butterbach-Bahl K, Baggs EM, Dannenmann M, Kiese R, Zechmeister-Boltenstern S (2013) Nitrous oxide emissions from soils: How well do we understand the processes and their controls? Philosophical Transactions of the Royal Society of London Series B: Biological Sciences, 368, doi: 10.1098/rstb.2013.0112.

Cannavo P, Lafolie F, Nicolardot B, Renault P (2006) Modeling seasonal variations in carbon dioxide and nitrous oxide in the vadose zone. Vadose Zone Journal, 5, 990-1004.

Clough TJ, Kelliher FM, Wang YP, Sherlock RR (2006) Diffusion of ${ }^{15} \mathrm{~N}$-labelled $\mathrm{N}_{2} \mathrm{O}$ into soil columns: A promising method to examine the fate of $\mathrm{N}_{2} \mathrm{O}$ in subsoils. Soil Biology and Biochemistry, 38, 1462-1468.

Davidson EA, Keller M, Erickson HE, Verchot LV, Veldkamp E (2000) Testing a conceptual model of soil emissions of nitrous and nitric oxides: Using two functions based on soil nitrogen availability and soil water content, the hole-inthe-pipe model characterizes a large fraction of the observed variation of nitric oxide and nitrous oxide emissions from soils. BioScience, 50, 667-680. 
Del Grosso SJ, Mosier AR, Parton WJ, Ojima DS (2005) DAYCENT model analysis of past and contemporary soil $\mathrm{N}_{2} \mathrm{O}$ and net greenhouse gas flux for major crops in the USA. Soil and Tillage Research, 83, 9-24.

Del Grosso SJ, Parton WJ, Mosier AR, Ojima DS, Kulmala AE, Phongpan S (2000) General model for $\mathrm{N}_{2} \mathrm{O}$ and $\mathrm{N}_{2}$ gas emissions from soils due to dentrification. Global Biogeochemical Cycles, 14, 1045-1060.

Dendooven L, Anderson JM (1995) Use of a "least square" optimization procedure to estimate enzyme characteristics and substrate affinities in the denitrification reactions in soil. Soil Biology and Biochemistry, 27, 1261-1270.

Dendooven L, Splatt P, Anderson JM, Scholefield D (1994) Kinetics of the denitrification process in a soil under permanent pasture. Soil Biology and Biochemistry, 26, 361-370.

Firestone MK, Davidson EA (1989) Microbiological basis of $\mathrm{NO}$ and $\mathrm{N}_{2} \mathrm{O}$ production and consumption in soil. In: Exchange of Trace Gases between Terrestrial Ecosystems and the Atmosphere. Report of the Dahlem Workshop, Berlin 1989, February 19-24. (eds Andreae M, Schimel D) pp 7-21. Chichester, John Wiley \& Sons. 
Firestone MK, Tiedje JM (1979) Temporal change in nitrous oxide and dinitrogen from denitrification following onset of anaerobiosis. Appl Environ Microbiol, 38, 673-679.

Grant RF, Pattey E (2003) Modelling variability in $\mathrm{N}_{2} \mathrm{O}$ emissions from fertilized agricultural fields. Soil Biology and Biochemistry, 35, 225-243.

Hansen S, Jensen HE, Nielsen NE, Svendsen H (1991) Simulation of nitrogen dynamics and biomass production in winter wheat using the Danish simulation model DAISY. Fertilizer Research, 27, 245-259.

Heincke M, Kaupenjohann M (1999) Effects of soil solution on the dynamics of $\mathrm{N}_{2} \mathrm{O}$ emissions: A review. Nutrient Cycling in Agroecosystems, 55, 133-157.

Hosen Y, Tsuruta H, Minami K (2000) Effects of the depth of $\mathrm{NO}$ and $\mathrm{N}_{2} \mathrm{O}$ productions in soil on their emission rates to the atmosphere: Analysis by a simulation model. Nutrient Cycling in Agroecosystems, 57, 83-98.

IPCC (2001) Climate Change 2001: The Scientific Basis. Contribution of Working Group 1 to the Third Assessment Report of the Intergovernmental Panel on Climate Change, Cambridge University Press, Cambridge, United Kingdom and New York, NY, USA. 
IPCC (2007) Climate Change 2007: The Physical Science Basis. Contribution of Working Group I to the Fourth Assessment Report of the Intergovernmental Panel on Climate Change, Rep., Cambridge University Press, Cambridge, United Kingdom and New York, NY, USA.

Kim DG, Vargas R, Bond-Lamberty B, Turetsky MR (2012) Effects of soil rewetting and thawing on soil gas fluxes: A review of current literature and suggestions for future research. Biogeosciences, 9, 2459-2483.

Li C, Frolking S, Frolking TA (1992) A model of nitrous oxide evolution from soil driven by rainfall events: 1 . Model structure and sensitivity. Journal of Geophysical Research: Atmospheres, 97, 9759-9776.

Li C, Narayanan V, Harriss RC (1996) Model estimates of nitrous oxide emissions from agricultural lands in the United States. Global Biogeochemical Cycles, 10, 297-306.

Linn D, Doran J (1984) Effect of water-filled pore space on carbon dioxide and nitrous oxide production in tilled and nontilled soils. Soil Science Society of America Journal, 48, 1267-1272. 
Lundquist EJ, Jackson LE, Scow KM (1999) Wet-dry cycles affect dissolved organic carbon in two California agricultural soils. Soil Biology and Biochemistry, 31, 1031-1038.

MacFarling Meure C, Etheridge D, Trudinger C et al. (2006) Law Dome $\mathrm{CO}_{2}, \mathrm{CH}_{4}$ and $\mathrm{N}_{2} \mathrm{O}$ ice core records extended to 2000 years BP. Geophysical Research Letters, 33, L14810, doi:10.1029/2006GL026152.

Maggi F, Gu C, Riley WJ et al. (2008) A mechanistic treatment of the dominant soil nitrogen cycling processes: Model development, testing, and application. Journal of Geophysical Research, G02016, doi:10.1029/2007JG000578.

Marshall TJ (1959) The diffusion of gases through porous media. Journal of Soil Science, 10, 79-82.

Matthias AD, Blackmer AM, Bremner JM (1980) A simple chamber technique for field measurement of emissions of nitrous oxide from soils1. Journal of Environmental Quality, 9, 251-256.

Matthias AD, Yarger DN, Weinbeck RS (1978) A numerical evaluation of chamber methods for determining gas fluxes. Geophysical Research Letters, 5, 765-768. 
Metivier KA, Pattey E, Grant RF (2009) Using the ecosys mathematical model to simulate temporal variability of nitrous oxide emissions from a fertilized agricultural soil. Soil Biology and Biochemistry, 41, 2370-2386.

Millington RJ, Quirk JP (1960) Transport in porous media. Transactions of the 7th International Congress on Soil Science, 1, 97-106.

Millington RJ, Quirk JP (1961) Permeability of porous solids. Transactions of the Faraday Society, 57, 1200-1207.

Moldrup P, Olesen T, Schjønning P, Yamaguchi T, Rolston DE (2000) Predicting the gas diffusion coefficient in undisturbed soil from soil water characteristics. Soil Science Society of America Journal, 64, 94-100.

Morley N, Baggs EM, Dorsch P, Bakken L (2008) Production of NO, $\mathrm{N}_{2} \mathrm{O}$ and $\mathrm{N}_{2}$ by extracted soil bacteria, regulation by $\mathrm{NO}_{2}{ }^{-}$and $\mathrm{O}_{2}$ concentrations. FEMS Microbiology Ecology, 65, 102-112.

NADP (2012) National Atmospheric Depostion Program http://nadp.isws.illinois.edu/. 
Illinois Climate Network (2012) sponsored by Illinois State Water Survey http://www.isws.illinois.edu/warm/datatype.asp.

Nobre A, Keller M, Crill P, Harriss R (2001) Short-term nitrous oxide profile dynamics and emissions response to water, nitrogen and carbon additions in two tropical soils. Biology and Fertility of Soils, 34, 363-373.

Parkin TB, Kaspar TC (2006) Nitrous oxide emissions from corn-soybean systems in the Midwest. Journal of Environmental Quality, 35, 1496-1506.

Ravishankara AR, Daniel JS, Portmann RW (2009) Nitrous oxide $\left(\mathrm{N}_{2} \mathrm{O}\right)$ : The dominant ozone-depleting substance emitted in the 21st Century. Science, 326, $123-125$.

Smith KA, Clayton H, Mctaggart IP et al. (1995) The measurement of nitrous oxide emissions from soil by using chambers. Philosophical Transactions: Physical Sciences and Engineering, 351, 327-338.

Stolk PC, Hendriks RFA, Jacobs CMJ, Moors EJ, Kabat P (2011) Modelling the effect of aggregates on $\mathrm{N}_{2} \mathrm{O}$ emission from denitrification in an agricultural peat soil. Biogeosciences, 8, 2649-2663. 
Yoh M, Toda H, Kanda K-I, Tsuruta H (1997) Diffusion analysis of $\mathrm{N}_{2} \mathrm{O}$ cycling in a fertilized soil. Nutrient Cycling in Agroecosystems, 49, 29-33.

Zheng J, Doskey PV (2014) Modeling nitrous oxide production and reduction in soil through explicit representation of denitrification enzyme kinetics. Environmental Science and Technology, submitted.

Zumft WG (1997) Cell biology and molecular basis of denitrification. Microbiology and Molecular Biology Reviews, 61, 533-616. 
Table 3.1 Parameterizations of the relative soil gas diffusivity.

\begin{tabular}{cl}
\hline Parameterization & \multicolumn{1}{c}{ Source } \\
\hline$D_{e} / D_{0}=\theta_{a}^{1.5}$ & Marshall, 1959 \\
$D_{e} / D_{0}=\theta_{a}^{3.1} \theta_{r}^{-2}$ & Millington \& Quirk, 1960 \\
$D_{e} / D_{0}=\theta_{a}^{2} \theta_{r}^{-2 / 3}$ & Millington \& Quirk, 1961 \\
$D_{e} / D_{0}=\theta_{a}^{2.5} \theta_{r}^{-1}$ & Moldrup et al., 2000 \\
$D_{e} / D_{0}=\theta_{a}^{2.5} \theta_{r}^{-1.3}$ & Bartelt-Hunt \& Smith, 2002 \\
$D_{e} / D_{0}=1.12 \theta_{a}^{2.13}$ & Cannavo et al., 2006 \\
\hline
\end{tabular}


Table 3.2 Effective diffusion coefficients, gross $\mathrm{N}_{2} \mathrm{O}$ production rates, and maximum $\mathrm{N}_{2} \mathrm{O}$ reduction rates estimated through metabolic modeling of incubations of soil core sections collected prior to the first rainfall addition (Zheng \& Doskey, 2014).

\begin{tabular}{|c|c|c|c|}
\hline Depth & $\begin{array}{c}D e \\
\left(\mathrm{~cm}^{2} \mathrm{~s}^{-1}\right)\end{array}$ & 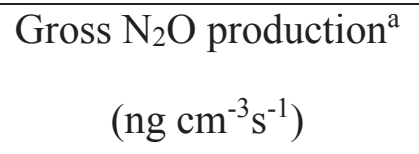 & $\begin{array}{c}\text { Maximum } \mathrm{N}_{2} \mathrm{O} \text { reduction } \\
\\
\left(\mathrm{ng} \mathrm{cm}^{-3} \mathrm{~s}^{-1}\right)\end{array}$ \\
\hline $0-5 \mathrm{~cm}$ & 0.0052 & $1 \times 10^{-4}$ & $2.6 \times 10^{-3}$ \\
\hline $5-10 \mathrm{~cm}$ & 0.0040 & $1 \times 10^{-4}$ & $2.6 \times 10^{-3}$ \\
\hline $10-15 \mathrm{~cm}$ & 0.0043 & $1.5 \times 10^{-4}$ & $7 \times 10^{-4}$ \\
\hline $15-25 \mathrm{~cm}$ & 0.0060 & $1.5 \times 10^{-4}$ & $7 \times 10^{-4}$ \\
\hline
\end{tabular}

aProduction rate estimated in the presence of $2-5 \%(\mathrm{v} / \mathrm{v})$ gas phase $\mathrm{O}_{2}$.

${ }^{b}$ Maximum $\mathrm{N}_{2} \mathrm{O}$ reduction rate estimated under complete $\mathrm{O}_{2}$ depletion. 


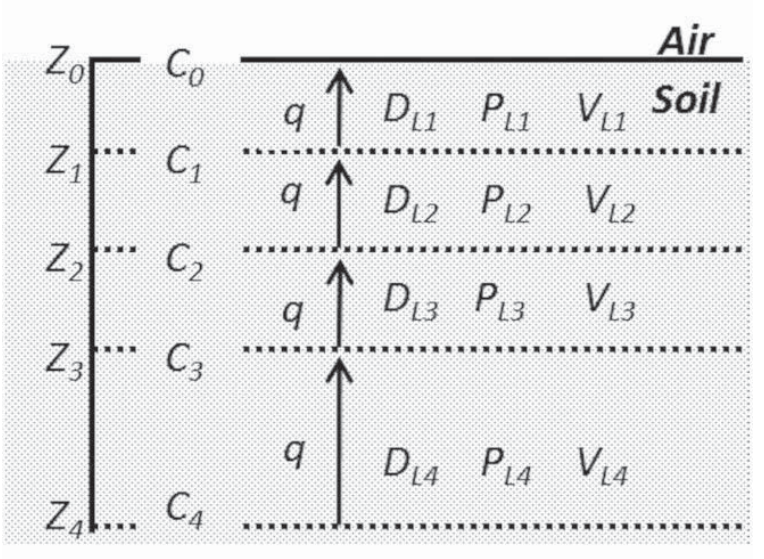

Fig. 3.1 The coupled soil gas diffusion/denitrification modeling scheme for simulating dynamics of $\mathrm{N}_{2} \mathrm{O}$ in the soil column. Average values of the effective diffusion coefficients $(D), \mathrm{N}_{2} \mathrm{O}$ production rates $(P)$, and maximum $\mathrm{N}_{2} \mathrm{O}$ reduction rates $(V)$ within each soil layer [i.e., L1 $(0-5 \mathrm{~cm}), \mathrm{L} 2(5-10 \mathrm{~cm}), \mathrm{L} 3(10-15 \mathrm{~cm})$, and L4 $(15-25 \mathrm{~cm})]$ were used in the coupled model. 


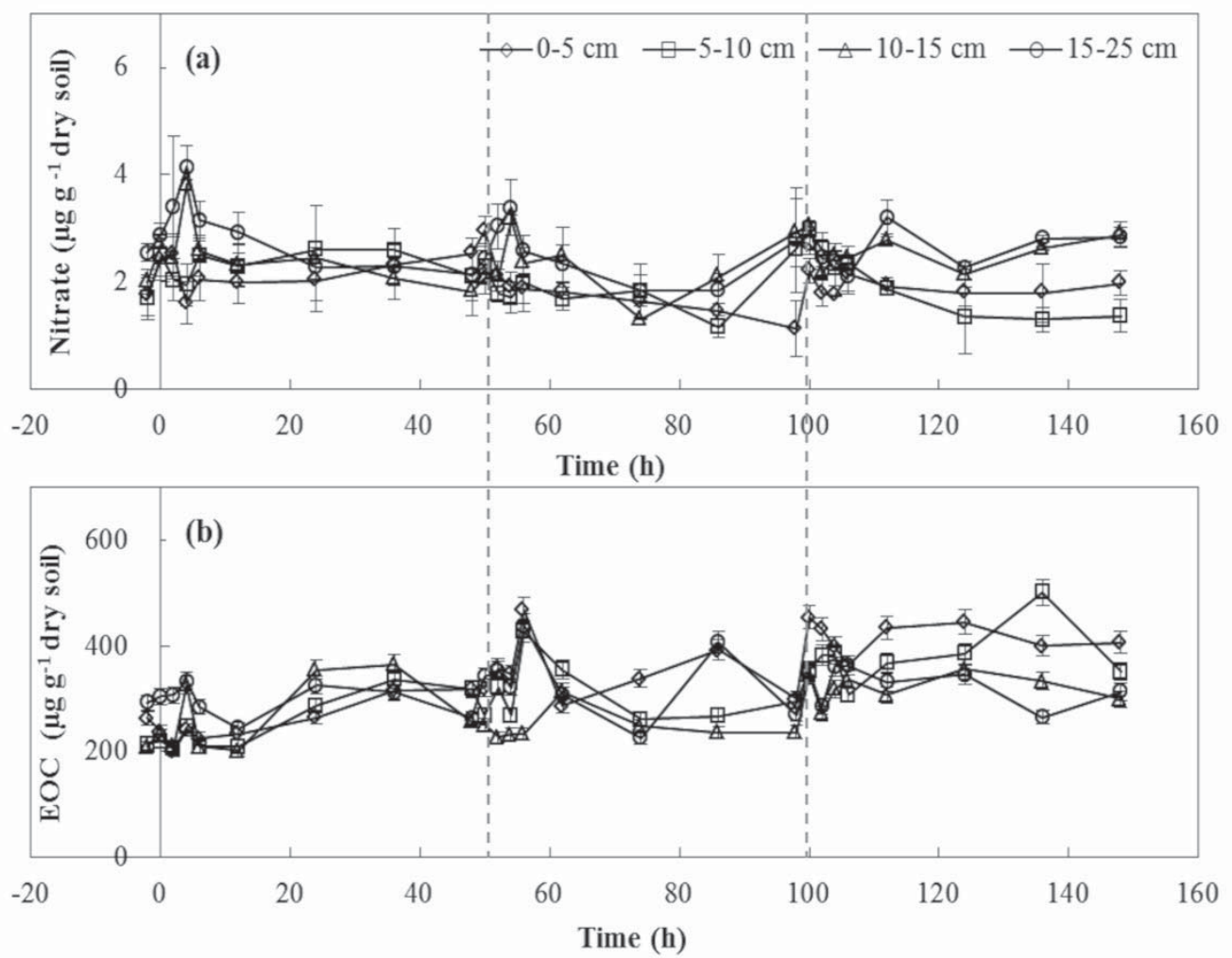

Fig. 3.2 Temporal variations of the levels of extractable $\mathrm{NO}_{3}{ }^{-}$and $\mathrm{EOC}$ during the field experiment. (Rainfall additions occurred $2 \mathrm{~h}$ prior to 0,48 , and $96 \mathrm{~h}$ and are marked by dashed lines for the second and third rainfall simulations.) 


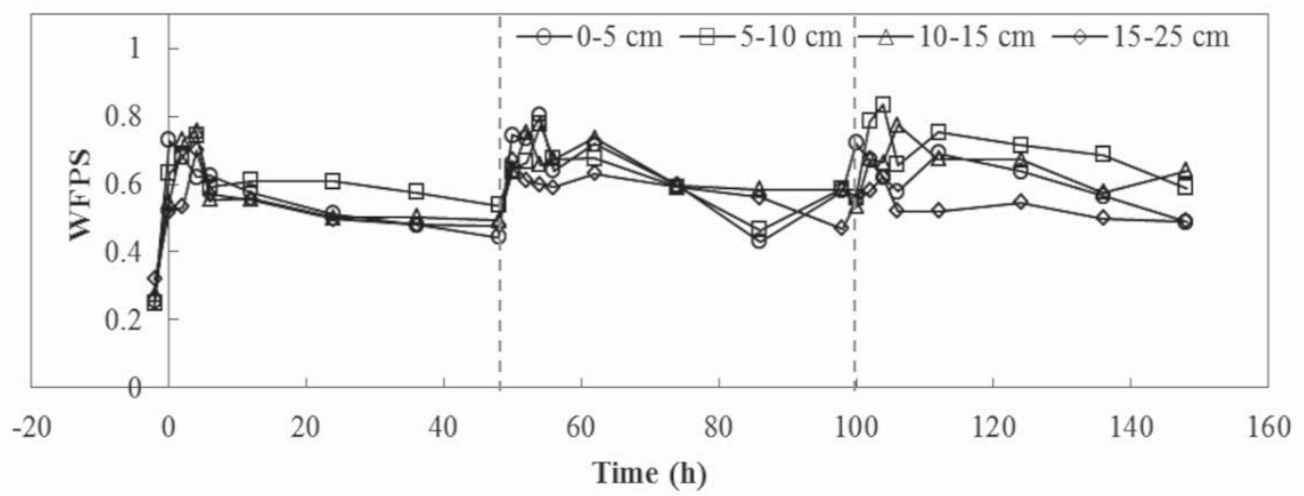

Fig. 3.3 Temporal variations of WFPS within 4 layers of the soil column during the field experiment. (Rainfall additions occurred $2 \mathrm{~h}$ prior to 0,48 , and $96 \mathrm{~h}$ and are marked by dashed lines for the second and third rainfall simulations.) 


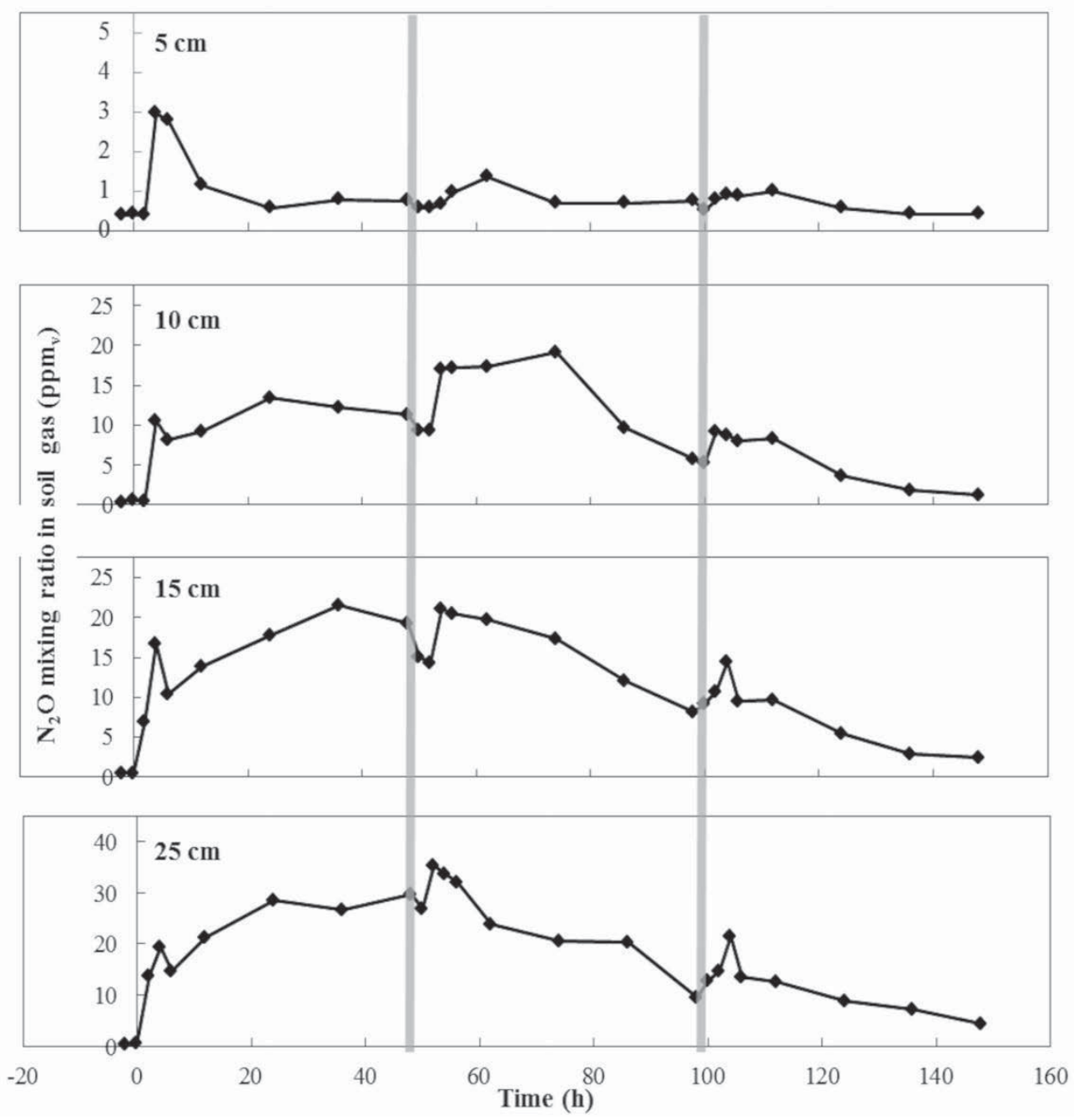

Fig. 3.4 Temporal variations of $\mathrm{N}_{2} \mathrm{O}$ mixing ratios in soil gas within 4 layers of the soil column during the experiment. (Rainfall additions occurred $2 \mathrm{~h}$ prior to 0,48 , and $96 \mathrm{~h}$ and are marked by gray lines for the second and third rainfall simulations.) 


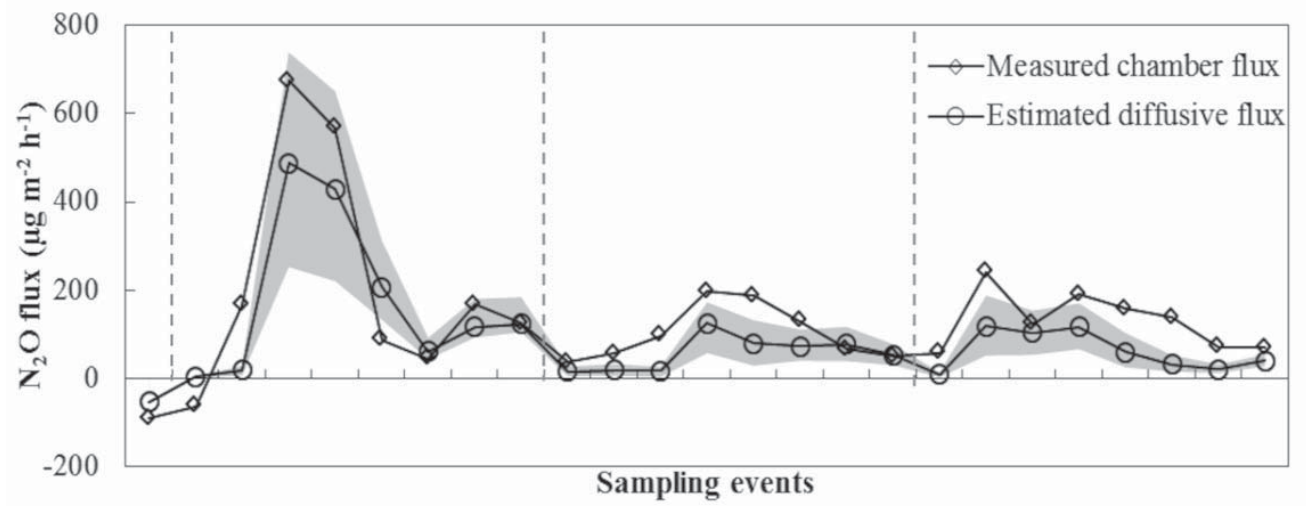

Fig. 3.5 Comparison of temporal variations of the model-simulated diffusive flux (without considering production or reduction of $\mathrm{N}_{2} \mathrm{O}$ ) from a soil depth of $5 \mathrm{~cm}$ with the measured flux $\left(\mathrm{R}^{2}=0.83\right)$. [The grey area represents the extent of model simulations using minimum and maximum values of $\mathrm{D}_{\mathrm{e}}$ estimated with the Millington and Quirk (1960) and Marshall (1959) parameterizations, respectively.] 


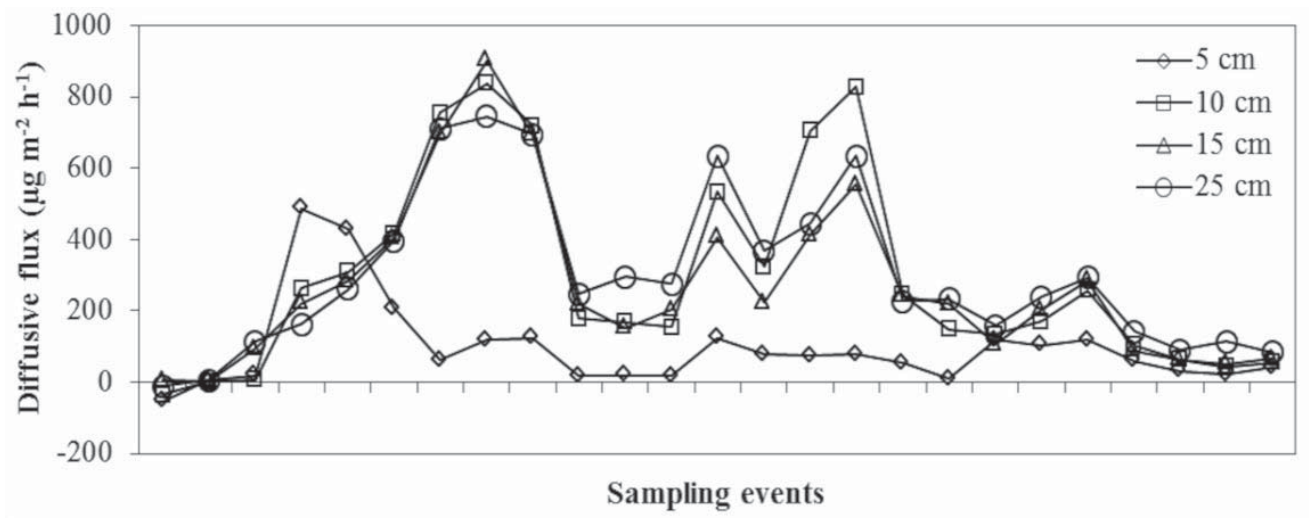

Fig. 3.6 Diffusive flux (without considering production or reduction of $\mathrm{N}_{2} \mathrm{O}$ ) from 4 layers of the soil column during the field experiment estimated with Bartelt-Hunt and Smith's (2002) soil gas diffusivity model $\left(D_{e} / D_{0}=\theta_{a}^{2.5} \theta_{r}^{-1.3}\right)$. 

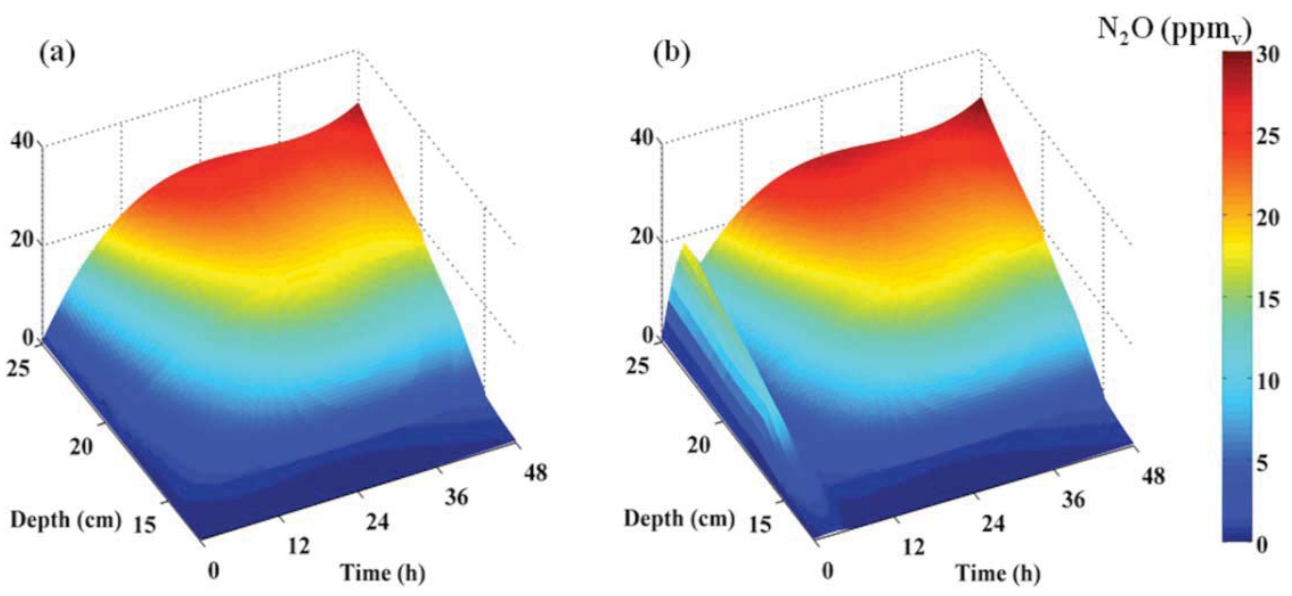

Fig. 3.7 Simulations of the dynamics of $\mathrm{N}_{2} \mathrm{O}$ in soil gas during the field experiment with the coupled soil gas diffusion/denitrification model (a) without and (b) with the contributions of constitutive denitrification enzymes. 


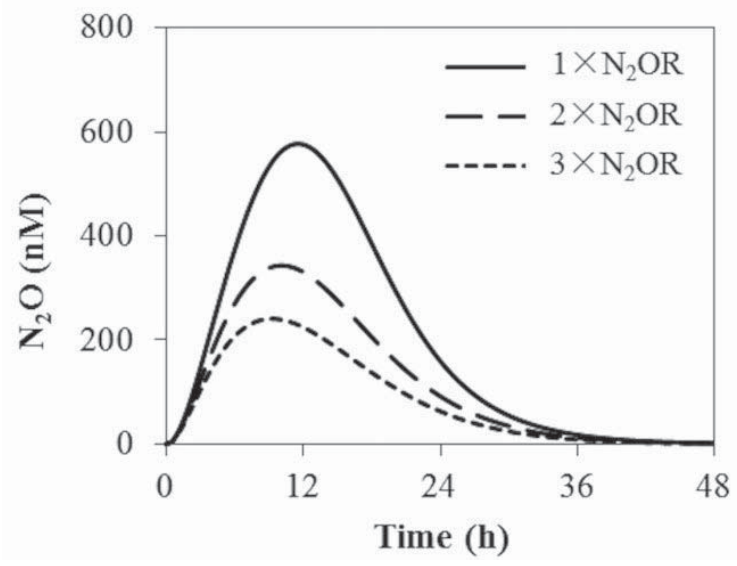

Fig. 3.8 Simulations of the dynamics of $\mathrm{N}_{2} \mathrm{O}$ using the metabolic denitrification model with different pool sizes of $\mathrm{N}_{2} \mathrm{OR}$ under constant $\mathrm{O}_{2}$ concentration $(2 \% \mathrm{v} / \mathrm{v})$. 


\section{Chapter 4}

\section{Delayed synthesis of $\mathrm{N}_{2} \mathrm{OR}$ explains dynamics of $\mathrm{N}_{2} \mathrm{O}$ in agricultural soil following rainfall ${ }^{\mathrm{III}}$}

Jianqiu Zheng ${ }^{1}$ and Paul V. Doskey ${ }^{1,2,3^{*}}$

${ }^{1}$ Atmospheric Sciences Program, Michigan Technological University, Houghton, Michigan 49931, USA, ${ }^{2}$ Department of Civil and Environmental Engineering, Michigan Technological University, Houghton, Michigan 49931, USA, ${ }^{3}$ School of Forest Resources and Environmental Science, Michigan Technological University, Houghton, Michigan 49931, USA. *e-mail: pvdoskey@mtu.edu

Precipitation is a major driver of nitrous oxide $\left(\mathrm{N}_{2} \mathrm{O}\right)$ production in soils and episodic $\mathrm{N}_{2} \mathrm{O}$ emissions. Global climate models project an increased intensity and magnitude of precipitation that will likely alter future $\mathrm{N}_{2} \mathrm{O}$ emissions. Thus, advancing understanding of biological and physical regulators of $\mathrm{N}_{2} \mathrm{O}$ emissions is needed to improve assessments of $\mathrm{N}_{2} \mathrm{O}$ inventories under future climate change scenarios. A comprehensive field study of the response of soil processes to a simulated precipitation event was combined with laboratory and modeling experiments to examine biogeochemical regulators of $\mathrm{N}_{2} \mathrm{O}$ emissions from an agricultural soil. Distinct regulation regimes for activities of pre-synthesized and de novo synthesized denitrification enzymes were observed. The activity of nitrous oxide reductase $\left(\mathrm{N}_{2} \mathrm{OR}\right)$ played a crucial role in regulating $\mathrm{N}_{2} \mathrm{O}$ fluxes. The $\mathrm{N}_{2} \mathrm{O}$ dynamics following precipitation were accurately simulated with a

\footnotetext{
III The manuscript has been submitted to Nature Geosciences.
} 
coupled soil gas diffusion/denitrification model that included explicit representation of denitrification enzyme kinetics and delayed $\mathrm{N}_{2} \mathrm{OR}$ synthesis. Oxygen $\left(\mathrm{O}_{2}\right)$ acted as the key regulator of enzyme kinetics and linked field measurements with laboratory simulations. Incorporating representations of denitrification enzyme kinetics driven by $\mathrm{O}_{2}$ tension in current soil $\mathrm{N}$ transformation models would improve assessments of $\mathrm{N}_{2} \mathrm{O}$ emission inventories.

\section{INTRODUCTION}

Nitrous oxide $\left(\mathrm{N}_{2} \mathrm{O}\right)$ is a long-lived greenhouse gas and plays a leading role in stratospheric ozone depletion ${ }^{1}$. Atmospheric $\mathrm{N}_{2} \mathrm{O}$ concentrations have increased by $21 \%$ following the onset of the industrial revolution ${ }^{2}$ and the trend is predicted to continue into the future due to emissions from soil ${ }^{3}$. Global $\mathrm{N}_{2} \mathrm{O}$ emissions from cultivated soils have been estimated at 4.2 $\mathrm{Tg} \mathrm{yr}^{-1}$, which accounts for $50 \%$ of global anthropogenic $\mathrm{N}_{2} \mathrm{O}$ sources ${ }^{4}$. Precipitation is a major driver of episodic emissions of $\mathrm{N}_{2} \mathrm{O}$ from soil through regulation of microbial denitrification and soil gas

movement ${ }^{5}$. General circulation models forecast an increasing intensity and frequency of heavy precipitation events for many parts of the world ${ }^{6}$, which is likely to affect the pattern and inventory of $\mathrm{N}_{2} \mathrm{O}$ emissions at regional and global scales.

Simulations of $\mathrm{N}_{2} \mathrm{O}$ emissions using biogeochemical models like DAYCENT ${ }^{7,8}$, $\mathrm{DNDC}^{9,10}$, DAISY ${ }^{11}$, and ECOSYS ${ }^{12,13}$ are in general agreement with low-temporal resolution measurements of surface fluxes. However, the models have difficulty in simulating the dynamics of $\mathrm{N}_{2} \mathrm{O}$ emissions following precipitation. Current models 
simulate the reduction sequence of denitrification through dual substrate (i.e., carbon and electron acceptors) Monod growth kinetics with the onset of denitrification occurring immediately upon suitable $\mathrm{O}_{2}$ tensions for anaerobic metabolism ${ }^{9,13}$. However, there are lags between activation of different denitrifying enzymes ${ }^{14}$. Activation of $\mathrm{N}_{2} \mathrm{O}$ reductase $\left(\mathrm{N}_{2} \mathrm{OR}\right)$ requires prolonged (20-40 h) anaerobic conditions that lead to rapid accumulation of $\mathrm{N}_{2} \mathrm{O}^{15,16,17}$. Ignoring the lag time limits the ability of current biogeochemical models to simulate the dynamics of $\mathrm{N}_{2} \mathrm{O}$ emissions induced by precipitation. Kinetic information from ongoing studies of denitrification enzymes, particularly $\mathrm{N}_{2} \mathrm{OR}$, provide new representations of denitrification kinetics that will improve the ability of current biogeochemical models to simulate the complex dynamics of $\mathrm{N}_{2} \mathrm{O}$ emissions from soil and reduce uncertainties in $\mathrm{N}_{2} \mathrm{O}$ emission inventories ${ }^{18}$.

\section{DYNAMICS OF $\mathrm{N}_{2} \mathrm{O}$ FOLLOWING RAINFALL}

Two pulses of $\mathrm{N}_{2} \mathrm{O}$ emissions were observed over a $24 \mathrm{~h}$ period following a 44 $\mathrm{mm}$ precipitation event during a 2010 pilot study of $\mathrm{N}_{2} \mathrm{O}$ emissions from an agricultural field planted with soybeans. Emissions were 201, 116, and $178 \mu \mathrm{g} \mathrm{m}^{-2} \mathrm{~h}^{-}$ ${ }^{1}$ at 6,12 , and $24 \mathrm{~h}$, respectively, following the rainfall (Fig. 4.1a). The microbial population regulates production and consumption of $\mathrm{N}_{2} \mathrm{O}$, and thus, the denitrifier abundance and activity are expected to be correlated with $\mathrm{N}_{2} \mathrm{O}$ emissions ${ }^{19}$. However, significant growth was found $24 \mathrm{~h}$ after the rainfall (Table 4.S1). The first $\mathrm{N}_{2} \mathrm{O}$ emission pulse at $6 \mathrm{~h}$ was not associated with microbial biomass growth and was likely due to unbalanced $\mathrm{N}_{2} \mathrm{O}$ production and reduction. A simulation of 
sequential precipitation events was conducted at the same site in $2012^{20}$ to investigate the pattern of $\mathrm{N}_{2} \mathrm{O}$ emissions with greater temporal resolution and to relate surface fluxes from the soybean surface to activities of the denitrifying community. Simultaneous measurements of $\mathrm{N}_{2} \mathrm{O}$ mixing ratios in soil gas, surface fluxes, and soil biogeochemical properties were made with fine temporal resolution. Here we report results from (1) a comprehensive survey of microbial community composition and functional gene abundances, nutrients, and $\mathrm{O}_{2}$ levels from a simulation of sequential precipitation events, (2) a laboratory study of soil core incubations and, (3) a modeling study to investigate regulators of microbial production/reduction of $\mathrm{N}_{2} \mathrm{O}$ in soil and the resultant surface flux.

The surface flux of $\mathrm{N}_{2} \mathrm{O}$ following a single rainfall addition of $44 \mathrm{~mm}$ in $2 \mathrm{~h}$ exhibited a two-pulse emission pattern that was similar to the temporal profile in emissions observed after the natural rainfall (Fig. 4.1a). Maxima in $\mathrm{N}_{2} \mathrm{O}$ emissions were 673 and $168 \mu \mathrm{g} \mathrm{m}^{-2} \mathrm{~h}^{-1}$ at 4 and $36 \mathrm{~h}$, respectively $(\mathrm{p}<0.05)$. Levels of $\mathrm{N}_{2} \mathrm{O}$ in soil gas increased rapidly from $0.56-0.90 \mathrm{ng} \mathrm{cm}^{-3}$ (about 310-500 $\mathrm{ppb}_{\mathrm{v}}$ ) before the rainfall addition to $35 \mathrm{ng} \mathrm{cm}^{-3}$ (about $19 \mathrm{ppm}_{\mathrm{v}}$ ) $4 \mathrm{~h}$ following the simulation and were correlated with the surface flux. A decrease in the surface flux of $\mathrm{N}_{2} \mathrm{O}$ at $6 \mathrm{~h}(568 \mu \mathrm{g}$ $\mathrm{m}^{-2} \mathrm{~h}^{-1}$ ) following the rainfall addition was concomitant with a decrease in mixing ratios of $\mathrm{N}_{2} \mathrm{O}$ in soil gas (Fig. 4.1b). Mixing ratios of $\mathrm{N}_{2} \mathrm{O}$ in soil gas at depths of 10, 15 , and $25 \mathrm{~cm}$ at $12-48 \mathrm{~h}$ following the rainfall addition were relatively invariant and remained at $\mathrm{ppm}_{\mathrm{v}}$ levels. Mixing ratios at a depth of $5 \mathrm{~cm}$ during the same period were much lower and followed the same trend as the diminishing surface fluxes. 
Estimates of the diffusive flux from soil derived from the gradient in $\mathrm{N}_{2} \mathrm{O}$ mixing ratios between ambient air and a depth of $5 \mathrm{~cm}$ followed the same 2-pulse trend as the measured surface flux (Fig. 4.S1). However, dynamics of the estimated diffusive flux from deeper layers were distinct and suggested mixing ratios of $\mathrm{N}_{2} \mathrm{O}$ in soil gas below $5 \mathrm{~cm}$ were more greatly influenced by microbial production and consumption and longer residence times of $\mathrm{N}_{2} \mathrm{O}$ in the soil column.

\section{MODELING OF N $\mathrm{N}_{2} \mathrm{O}$ PRODUCTION AND REDUCTION}

Soil cores collected before the rainfall addition were incubated under anaerobic conditions and the dynamics of $\mathrm{N}_{2} \mathrm{O}$ production/reduction were examined with a kinetic model ${ }^{17}$. A non-negligible contribution of denitrification activity from constitutive denitrification enzymes (i.e., defined here as pre-synthesized or constitutively synthesized denitrification proteome) was demonstrated by comparing soil core incubations treated with and without chloramphenicol to inhibit de novo synthesis of denitrification enzymes. The observed enzyme dynamics were explicitly implemented in the denitrification kinetic model by introducing a dimensionless factor to represent the pool size of active denitrification enzymes. Contributions from constitutive denitrification enzymes normalized to microbial biomass increased with soil depth and represented $23,22,48$, and $78 \%$ of the total cumulative $\mathrm{N}_{2} \mathrm{O}$ production during incubations of the $0-5,5-10,10-15$, and $15-25 \mathrm{~cm}$ soil core sections, respectively. Activity of $\mathrm{N}_{2} \mathrm{OR}$ in the soil core incubations was observed about 6-24 hours later than the other three denitrification enzymes, i.e. nitrate 
reductase (NAR), nitrite reductase (NIR), and nitric oxide reductase (NOR), which is in agreement with previous studies ${ }^{15,16}$.

The abundance of functional genes as proxies of microorganisms involved in $\mathrm{N}_{2} \mathrm{O}$ production/reduction was quantified to further examine the dynamics of denitrification enzymes. Total microbial biomass growth, which was quantified through a correlation with phospholipid fatty acid (PLFA) content of soiler, dramatically increased $(\mathrm{p}<0.05)$ at $12 \mathrm{~h}$ following the rainfall addition and decreased significantly with soil depth $(\mathrm{p}<0.01)$. The nirK and nirS encoded 2 NIRs that are structurally different but functionally equivalent, and thus, abundances of nir $\mathrm{K}$ and nir $\mathrm{S}$ were used to evaluate organisms that can produce $\mathrm{N}_{2} \mathrm{O}$ through denitrification. Organisms possessing the ability to reduce $\mathrm{N}_{2} \mathrm{O}$ were quantified by targeting the nos Z gene ${ }^{22}$. Abundance of denitrification genes encoding NIR (nirK and nir S) and $\mathrm{N}_{2} \mathrm{OR}$ (nos Z) were measured with real-time PCR assays [average efficiencies were $92.22 \%$ (s.d. $\pm 2.43 \%$ ), permitting direct comparison of results for all targets]. The nirK $+n i r \mathrm{~S}$ was very persistent in the $15-25 \mathrm{~cm}$ soil core sections (Fig. 4.2), which coincided with high denitrifying activity and led to $\mathrm{N}_{2} \mathrm{O}$ production during the early stages of denitrification in the soil core incubations. Due to persistence of $n i r \mathrm{~K}+n i r \mathrm{~S}$, the correlation between copy numbers of $n i r \mathrm{~K}+n i r \mathrm{~S}$ and microbial biomass was low $\left(R^{2}=0.09\right)$; however, nosZ, which exhibits low persistence, was correlated with microbial biomass $\left(R^{2}=0.54\right)$. Thus, quantification of functional genes nirK, nirS, and nosZ from the field study was in agreement with 
the laboratory incubations that indicated $\mathrm{N}_{2} \mathrm{OR}$ was not part of the constitutive denitrification enzyme pool existing prior to rainfall addition.

A coupled soil gas diffusion/denitrification model was developed to simulate the accumulation of $\mathrm{N}_{2} \mathrm{O}$ in the soil column in response to simulated rainfall in the field ${ }^{20}$. Unlike the near-zero $\mathrm{O}_{2}$ concentrations in soil incubations, which ensured steady synthesis of denitrification enzymes and the progress of denitrification, $\mathrm{O}_{2}$ levels in soil gas following a precipitation event are regulated by infiltration of water, and thus, are highly dynamic. The $\mathrm{O}_{2}$ tensions likely inhibited expression of denitrification genes and enzyme syntheses during the drying period after the rainfall addition, particularly for $\mathrm{N}_{2} \mathrm{OR}$, which is more sensitive to $\mathrm{O}_{2}$ levels than NAR, NIR, and NOR. Rather than incorporate a reduction function in the coupled model, which is an approach used in biogeochemical models to link actual and potential denitrification rates, we estimated denitrification rates for the field experiment by adjusting $\mathrm{O}_{2}$ tensions in simulations of the soil incubation studies with a metabolic denitrification model (Fig. 4.S2) ${ }^{17}$. Activity of $\mathrm{N}_{2} \mathrm{OR}$ was severely depleted as $\mathrm{O}_{2}$ levels increased (Fig. 4.S3), which led to higher accumulations of $\mathrm{N}_{2} \mathrm{O}$. Oxygen exhibited a tight control on the activation and synthesis of $\mathrm{N}_{2} \mathrm{OR}$ and was the key parameter that linked the denitrification and diffusion processes ${ }^{23}$.

Simulations with a coupled soil gas diffusion/denitrification model, which includes $\mathrm{N}_{2} \mathrm{O}$ production and reduction, are shown in Fig. 4.3a. The dynamics of $\mathrm{N}_{2} \mathrm{O}$ mixing ratios in soil $6-48 \mathrm{~h}$ after the rainfall addition agreed with the field observations; however, rapid accumulation of $\mathrm{N}_{2} \mathrm{O}$ in soil gas within $6 \mathrm{~h}$ of the 
simulated rainfall were grossly underestimated. The 2-pulse pattern of $\mathrm{N}_{2} \mathrm{O}$ dynamics in soil gas was accurately simulated by including representations of denitrification activity associated with constitutive enzymes and growth of the microbial biomass (Fig. 4.3b). Production and rapid accumulation of $\mathrm{N}_{2} \mathrm{O}$ in soil gas within $4 \mathrm{~h}$ of the rainfall addition was attributed to activities of constitutive NAR, NIR and NOR and a lack of $\mathrm{N}_{2} \mathrm{OR}$ activity that does not persist in aerobic soils. The dynamics of $\mathrm{N}_{2} \mathrm{O}$ in soil gas after $4 \mathrm{~h}$ were regulated by $\mathrm{N}_{2} \mathrm{O}$ production/reduction activity associated with biomass growth.

\section{BIOTIC AND ABIOTIC CONTROLS ON DENITRIFICATION}

Multivariate analysis also suggested distinct regulators for net production of $\mathrm{N}_{2} \mathrm{O}$ that were associated with constitutive enzymes and the growing microbial biomass (Fig. 4.4a). The net rate of $\mathrm{N}_{2} \mathrm{O}$ production within $4 \mathrm{~h}$ of the simulated rainfall was highly correlated with levels of microbial substrates, i.e., extractable $\mathrm{NO}_{3}{ }^{-}$and organic carbon (EOC; $R^{2}=0.91$ and 0.73 , respectively). Gene copy numbers of $n i r \mathrm{~K}+n i r \mathrm{~S}$ did not exhibit a correlation with changes in microbial biomass; however, nos $\mathrm{Z}$ and microbial biomass were highly correlated $\left(R^{2}=0.82\right)$. The results confirm the presence of constitutive denitrification enzymes and the lack of $\mathrm{N}_{2} \mathrm{OR}$ during early stages of denitrification following anaerobiosis induced by the precipitation event. Net production of $\mathrm{N}_{2} \mathrm{O}$ within $4 \mathrm{~h}$ of the simulated rainfall was regulated by availability of $\mathrm{NO}_{3}{ }^{-}$and $\mathrm{EOC}$ to the constitutive denitrification enzymes; however, the net $\mathrm{N}_{2} \mathrm{O}$ production rate at 6-48 $\mathrm{h}$ was under multiple biotic and abiotic controls (Fig. 4.4b). Negative correlations of the net $\mathrm{N}_{2} \mathrm{O}$ production rate 
were found with microbial biomass $\left(R^{2}=-0.60\right)$, water-filled pore space (WFPS; $R^{2}$ $=-0.55)$ and gene copy numbers of nos $\mathrm{Z}\left(R^{2}=-0.39\right)$, which confirms biomass growth associated $\mathrm{N}_{2} \mathrm{O}$ reduction that was observed in the soil gas measurements and coupled model simulations. Thus, first-order kinetics and biomass growth kinetics can adequately forecast the net $\mathrm{N}_{2} \mathrm{O}$ production rate under the regimes occurring within $4 \mathrm{~h}$ and 6-48 $\mathrm{h}$, respectively, of the rainfall addition when dynamics of dentrification enzymes are accurately simulated ${ }^{5,24}$.

Biogeochemical models like DAYCENT and DAISY represent soil N transformation processes with first-order kinetic expressions and DNDC and ECOSYS include explicit representations of microbial growth and Michaelis-Menten reaction kinetics ${ }^{7,9,11,13,24,25}$. We applied DAISY and DNDC to predict the maximum in $\mathrm{N}_{2} \mathrm{O}$ emissions following the simulated rainfall. Estimated peak fluxes were 345 and $255 \mu \mathrm{g} \mathrm{m}^{-2} \mathrm{~h}^{-1}$ from DAISY and DNDC, respectively, which represented 51\% and $39 \%$ of the observed peak flux (Fig. 4.S4). The correlation between $\mathrm{N}_{2} \mathrm{O}$ emission dynamics simulated by DAISY and DNDC and the observations $\left(R^{2}=0.04\right.$ and $R^{2}=0.06$, respectively) were much lower than the correlation between emission dynamics simulated by the coupled soil gas diffusion/dentrification model $\left(R^{2}=0.83\right)$. Simulations of the 48-h cumulative $\mathrm{N}_{2} \mathrm{O}$ flux with DAISY, DNDC, and the coupled model were $146,90 \%$, and $93 \%$ respectively of the measured flux, respectively. The good agreement between DNDC and the coupled model appears to be coincidental. Much higher levels of $\mathrm{NO}_{3}{ }^{-}$, which is a key substrate for denitrification, are predicted by DNDC than the measured concentrations that were used to initialize the coupled 
model (Fig. 4.S4). A parameterization for the lag time between activation of denitrification enzymes is not included in $\mathrm{DNDC}^{9}$, which grossly under-predicted the surface flux of $\mathrm{N}_{2} \mathrm{O}$ attributed to constitutive enzymes. Simulations with the metabolic denitrification model, which included (1) a time lag for $\mathrm{N}_{2} \mathrm{OR}$ activation and (2) concurrent activation of NAR, NIR, and NOR, clearly demonstrated the importance of the time lag in reproducing $\mathrm{N}_{2} \mathrm{O}$ dynamics in soil gas. Accumulation of $\mathrm{N}_{2} \mathrm{O}$ was severely depleted when $\mathrm{N}_{2} \mathrm{OR}$ activity was coincident with activities of NAR, NIR, and NOR (Fig. 4.5), however, $\mathrm{N}_{2} \mathrm{O}$ accumulations over $48 \mathrm{~h}$ in both simulations were coincidently similar.

Delayed $\mathrm{N}_{2} \mathrm{OR}$ synthesis appears to be a common regulatory pattern among denitrifiers. The subject study demonstrated the importance of delayed $\mathrm{N}_{2} \mathrm{OR}$ synthesis in the dynamics of $\mathrm{N}_{2} \mathrm{O}$ in soils during the transition from aerobic to anaerobic conditions induced by precipitation. Activities of constitutive NAR, NIR and NOR, and a lack of $\mathrm{N}_{2} \mathrm{OR}$ exacerbated the lag effect between $\mathrm{N}_{2} \mathrm{OR}$ and the other three enzymes, leading to rapid $\mathrm{N}_{2} \mathrm{O}$ accumulation during the first few hours following the precipitation event. Thus, enzyme regulation, especially regulation of $\mathrm{N}_{2} \mathrm{OR}$, was demonstrated to be critical in accurately simulating $\mathrm{N}_{2} \mathrm{O}$ dynamics.

Mechanistic models that are driven by data consisting of temporal variations of $\mathrm{N}_{2} \mathrm{O}$ fluxes are needed to develop land use and land management strategies to mitigate climate change. Simulating episodic $\mathrm{N}_{2} \mathrm{O}$ emissions with next-generation soil gas diffusion models, which include descriptions of the dynamics of enzyme activation and activity in catalyzing sequential biochemical reactions, has been 
suggested as an approach to improve predictions of $\mathrm{N}_{2} \mathrm{O}$ emissions from soil ${ }^{5,18}$. The subject study demonstrated that accurate simulation of the dynamics of $\mathrm{N}_{2} \mathrm{O}$ in soil and surface fluxes is possible with a coupled soil gas diffusion/denitrification model that includes explicit representation of denitrification enzyme kinetics and a dimensionless factor to represent the initial activity of denitrification enzymes.

\section{METHODS}

The pilot study and the rainfall simulation experiment were conducted at the AmeriFlux site in Bondville, Illinois $\left(40^{\circ} 00^{\prime} \mathrm{N}, 88^{\circ} 18^{\prime} \mathrm{W}\right)$, which is the location of a corn/soybean cropping rotation. No-till agriculture is practiced at the site and the field was planted with soybeans during both experiments. A natural rainfall (44 mm) occurred on 09 June 2010 and emissions and soil was sampled $12 \mathrm{~h}$ preceding the event and 6,12 , and $24 \mathrm{~h}$ following the event. The rainfall simulation experiment was conducted on 19 July 2012 using a continuous-spray, single-nozzle rainfall simulator. A pulse of $44 \mathrm{~mm}$ of synthetic rainfall was delivered to a $1 \mathrm{~m} \times 1 \mathrm{~m}$ plot in $2 \mathrm{~h}$.

Measurements were made preceding the addition and at $0,2,4,6,12,24,36$, and $48 \mathrm{~h}$ after the rainfall addition. Emissions and both soil gas and soil (at depths of $5,10,15$, and $25 \mathrm{~cm}$ ) were collected during each sampling event ${ }^{20}$. Gas samples were injected into pre-evacuated 5.9-mL Exetainers with double-wadded caps (Labco International Inc., Houston, TX), pressurized to $203 \mathrm{kPa}$, and the puncture in the septa sealed with silicone. Mixing ratios of $\mathrm{N}_{2} \mathrm{O}$ were quantified with a high- 
resolution gas chromatograph with electron capture detector (HP5890; Hewlett Packard, Palo Alto, CA). Soil core sections were transferred to $15-\mathrm{mL}$ sterile plastic tubes (Fisher Scientific, Pittsburgh, PA), flash-frozen in the field in liquid $\mathrm{N}_{2}$, and transported to the laboratory in a liquid $\mathrm{N}_{2}$ dewar (PrincetonCryo, Flemington, NJ).

Subsamples of soil ( $3 \mathrm{~g})$ were incubated under anaerobic conditions in $5 \mathrm{~mL}$ of synthetic rainwater in $40-\mathrm{mL}$ amber vials sealed with mininert valves (Sigma Aldrich, St. Louis, MO). Samples included treatments with chloramphenicol (2.5 g $\left.\mathrm{L}^{-1}\right)$ and acetylene $(10 \% \mathrm{v} / \mathrm{v})$ to inhibit protein synthesis and $\mathrm{N}_{2} \mathrm{OR}$, respectively, to develop representations of denitrification kinetics ${ }^{17}$. Subsamples of soil were also analyzed to determine soil $\mathrm{pH}, \mathrm{WFPS}, \mathrm{NO}_{3}{ }^{-}$and EOC concentrations, and total PLFAs. Soil DNAs were extracted using the PowerSoil ${ }^{\circledR}$ DNA Isolation Kit (MO BIO Laboratories, Inc., Carlsbad, CA) and quantified using a Qubit ${ }^{\circledR} 2.0$ Fluorometer (Life Technologies, Grand Island, NY). Abundances of functional gene nirK, nirS, and nosZ were determined by qPCR using the SYBR Green approach. A complete list of primers can be found in Table 4.S2.

\section{Acknowledgements}

The authors acknowledge start-up funding, which supported Jianqiu Zheng, and an equipment loan to Paul V. Doskey through Michigan Technological University and Argonne National Laboratory, respectively. Partial support for Jianqiu Zheng

through the Atmospheric Sciences Program is also greatly appreciated. The authors 
are grateful to Robert Fritz for constructing the rainfall simulator, soil gas sampling probes, and flux chambers, and Keenan A. Murray for assistance with field sampling. We thank Chris Lehmann, Laboratory Director of the Central Analytical Laboratory of NADP, for supplying deionized water for the rainfall simulation study. 


\section{REFERENCES}

1. Ravishankara, A. R., Daniel, J. S. \& Portmann R. W. Nitrous oxide $\left(\mathrm{N}_{2} \mathrm{O}\right)$ :

The dominant ozone-depleting substance emitted in the 21st Century. Science 326, $123-125$ (2009).

2. MacFarling Meure, C. et al. Law Dome $\mathrm{CO}_{2}, \mathrm{CH}_{4}$ and $\mathrm{N}_{2} \mathrm{O}$ ice core records extended to 2000 years BP. Geophys. Res. Lett. 33, L14810, doi:10.1029/2006GL026152 (2006).

3. Bouwman, A. F. et al. Global trends and uncertainties in terrestrial denitrification and $\mathrm{N}_{2} \mathrm{O}$ emissions. Phil. T. Roy. Soc. B. 368, doi:10.1098/rstb.2013.0112 (2013).

4. IPCC. Climate Change 2001: The Scientific Basis. Contribution of Working Group 1 to the Third Assessment Report of the Intergovernmental Panel on Climate Change (Cambridge University Press, Cambridge, United Kingdom and New York, NY, USA, 2001).

5. Butterbach-Bahl, K., Baggs, E. M., Dannenmann, M., Kiese, R. \& Zechmeister-Boltenstern, S. Nitrous oxide emissions from soils: How well do 
we understand the processes and their controls? Phil. T. Roy. Soc. B. 368, doi: 10.1098/rstb.2013.0112 (2013).

6. IPCC. Climate Change 2007: The Physical Science Basis. Contribution of Working Group I to the Fourth Assessment Report of the Intergovernmental Panel on Climate Change (Cambridge University Press, Cambridge, United Kingdom and New York, NY, USA, 2007).

7. Del Grosso, S. J., Mosier, A. R., Parton, W. J. \& Ojima, D. S. DAYCENT model analysis of past and contemporary soil $\mathrm{N}_{2} \mathrm{O}$ and net greenhouse gas flux for major crops in the USA. Soil Till. Res. 83, 9-24 (2005).

8. Del Grosso, S. J. et al. General model for $\mathrm{N}_{2} \mathrm{O}$ and $\mathrm{N}_{2}$ gas emissions from soils due to dentrification. Global Biogeochem. Cy. 14, 1045-1060 (2000).

9. Li, C., Frolking, S. \& Frolking, T. A. A model of nitrous oxide evolution from soil driven by rainfall events: 1 . Model structure and sensitivity. $J$. Geophys. Res.-Atmos. 97, 9759-9776 (1992). 
10. Li, C., Narayanan, V. \& Harriss, R. C. Model estimates of nitrous oxide emissions from agricultural lands in the United States. Global Biogeochem. Cy. 10, 297-306 (1996).

11. Hansen, S., Jensen, H. E., Nielsen, N. E. \& Svendsen, H. Simulation of nitrogen dynamics and biomass production in winter wheat using the Danish simulation model DAISY. Fert. Res. 27, 245-259 (1991).

12. Grant, R. F. \& Pattey, E. Modelling variability in $\mathrm{N}_{2} \mathrm{O}$ emissions from fertilized agricultural fields. Soil Biol. Biochem. 35, 225-243 (2003).

13. Metivier, K. A., Pattey, E. \& Grant, R. F. Using the ecosys mathematical model to simulate temporal variability of nitrous oxide emissions from a fertilized agricultural soil. Soil Biol. Biochem. 41, 2370-2386 (2009).

14. van Spanning, R. J. M., Richardson, D. J. \& Ferguson, S. J. Introduction to the biochemistry and molecular biology of denitrification. Biology of the Nitrogen Cycle (Elsevier: Amsterdam, 2007). 
15. Dendooven, L. \& Anderson, J. M. Use of a "least square" optimization procedure to estimate enzyme characteristics and substrate affinities in the denitrification reactions in soil. Soil Biol. Biochem. 27, 1261-1270 (1995).

16. Firestone, M. K. \& Tiedje, J. M. Temporal change in nitrous oxide and dinitrogen from denitrification following onset of anaerobiosis. Appl. Environ. Microbiol. 38, 673-679 (1979).

17. Zheng, J. \& Doskey, P. V. Modeling nitrous oxide production and reduction in soil through explicit representation of denitrification enzyme kinetics. Environ. Sci. Technol. submitted (2014).

18. Richardson, D., Felgate, H., Watmough, N., Thomson, A. \& Baggs, E. Mitigating release of the potent greenhouse gas $\mathrm{N}_{2} \mathrm{O}$ from the nitrogen cycle - Could enzymic regulation hold the key? Trends Biotechnol. 27, 388-397 (2009).

19. Morales, S. E., Cosart, T. \& Holben, W. E. Bacterial gene abundances as indicators of greenhouse gas emission in soils. ISME J. 4, 799-808 (2010). 
20. Zheng, J. \& Doskey, P. V. Dynamics of nitrous oxide in soil gas and surface fluxes following simulation of sequential precipitation events. Glob. Change Bio. submitted (2014).

21. Bailey, V. L., Peacock, A. D., Smith, J. L. \& Bolton Jr., H. Relationships between soil microbial biomass determined by chloroform fumigationextraction, substrate-induced respiration, and phospholipid fatty acid analysis. Soil Biol. Biochem. 34, 1385-1389 (2002).

22. Jones, C. M. et al. Recently identified microbial guild mediates soil $\mathrm{N}_{2} \mathrm{O}$ sink capacity. Nature Clim. Change 4, 801-805 (2014).

23. Burgin, A. J. \& Groffman, P. M. Soil $\mathrm{O}_{2}$ controls denitrification rates and $\mathrm{N}_{2} \mathrm{O}$ yield in a riparian wetland. J. Geophys. Res. 117, G01010, doi:10.1029/2011JG001799 (2012).

24. Blagodatsky, S. \& Smith, P. Soil physics meets soil biology: Towards better mechanistic prediction of greenhouse gas emissions from soil. Soil Biol. Biochem., 47, 78-92 (2012). 
25. Heinen, M. Simplified denitrification models: Overview and properties.

Geoderma 133, 444-463 (2006). 


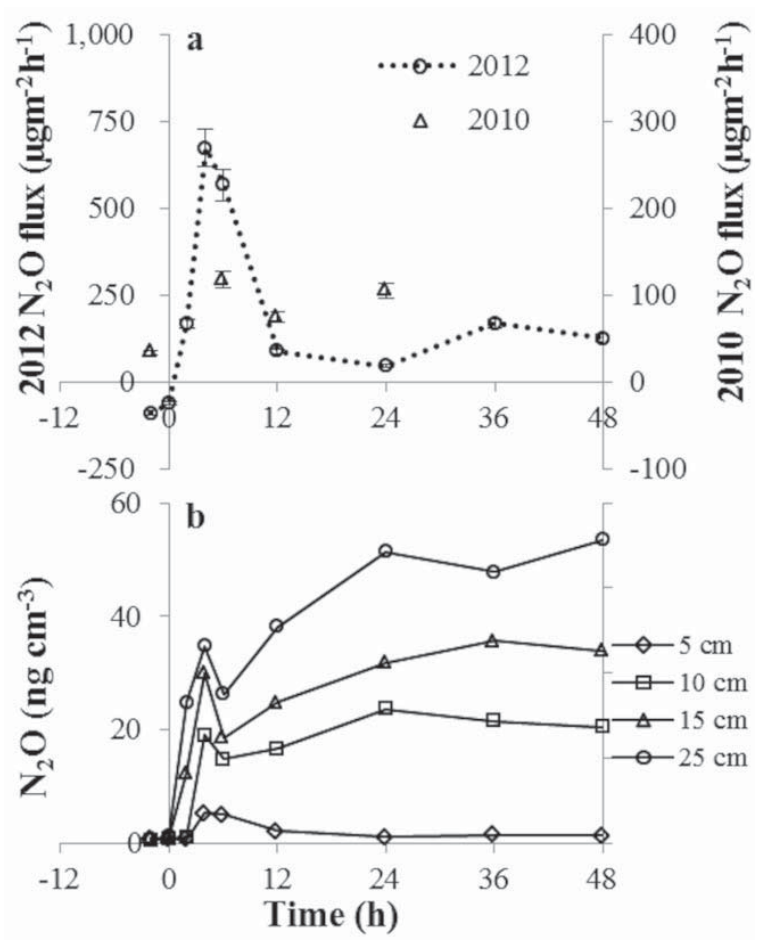

Figure 4.1 | Measurements of $\mathrm{N}_{2} \mathrm{O}$ fluxes and concentrations of $\mathrm{N}_{2} \mathrm{O}$ in soil gas.

a. Surface fluxes of $\mathrm{N}_{2} \mathrm{O}$ following a natural rainfall event in 2010 and after a simulated rainfall in 2012. b. Concentrations of $\mathrm{N}_{2} \mathrm{O}$ in soil gas at depths of 5, 10, 15, and $25 \mathrm{~cm}$ following a simulated rainfall in 2012 . 

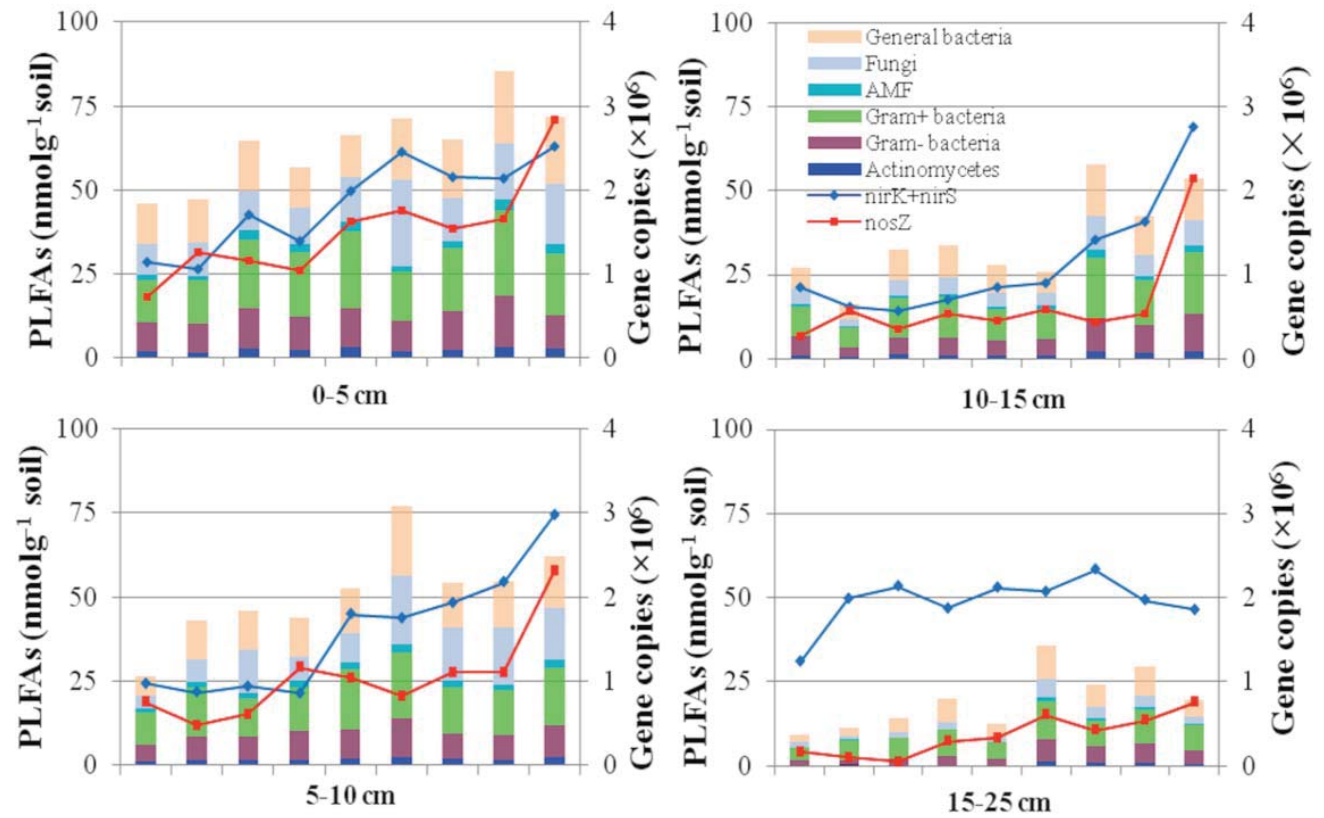

Figure 4.2 Temporal variations of PLFAs and denitrification genes with soil

depth. The PLFAs and gene copy numbers of nirK, nirS, and nosZ were determined in soils sampled before the simulated rainfall in 2012 and at $0,2,4,6,12,24,36$, and $48 \mathrm{~h}$ after the rainfall addition (i.e., sampling events $1-9$, respectively, on the $\mathrm{x}$-axis). 

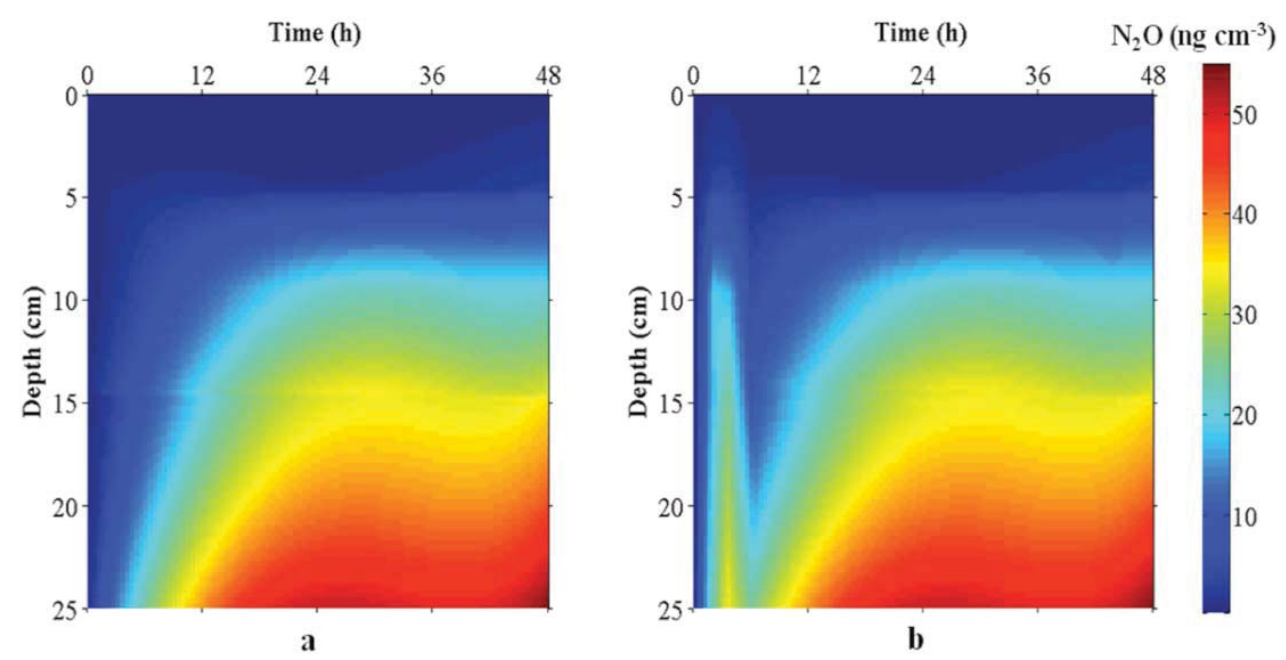

Figure 4.3 Simulations of the dynamics of $\mathrm{N}_{2} \mathrm{O}$ in soil gas with the coupled soil gas diffusion/denitrification model. a. Model simulation including parameterization for simultaneous activation of NAR, NIR, NOR, and $\mathrm{N}_{2} \mathrm{OR}$. b. Model simulation including parameterizations for constitutive denitrification enzymes that lack $\mathrm{N}_{2} \mathrm{OR}$ activity and growth-associated denitrification activity with synthesis of NAR, NIR, NOR, and $\mathrm{N}_{2} \mathrm{OR}$. 

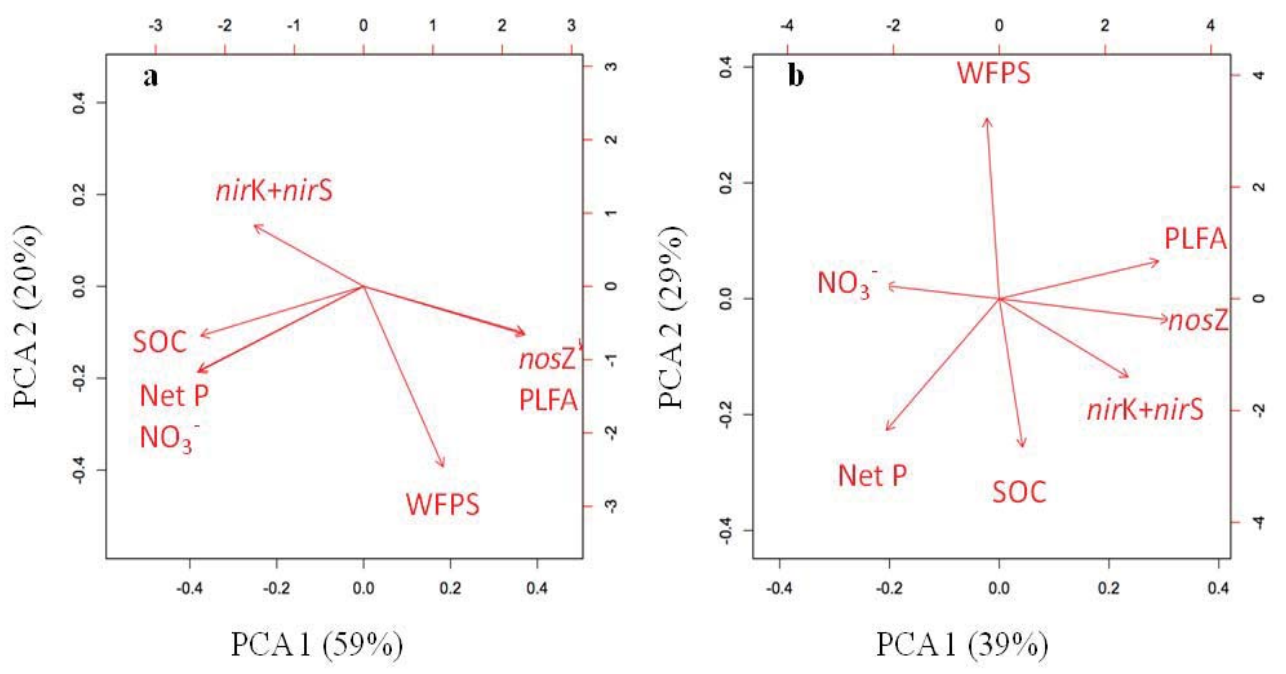

Figure 4.4 Multivariate analysis of biotic and abiotic controls on net

production of $\mathrm{N}_{2} \mathrm{O}$ in soil. Multivariate analysis of constituents in soil core sections sampled at 4 different depths a. At 0,2 , and $4 \mathrm{~h}$ following the simulated rainfall and b. At $6,12,24,36$, and $48 \mathrm{~h}$ after the rainfall addition. 


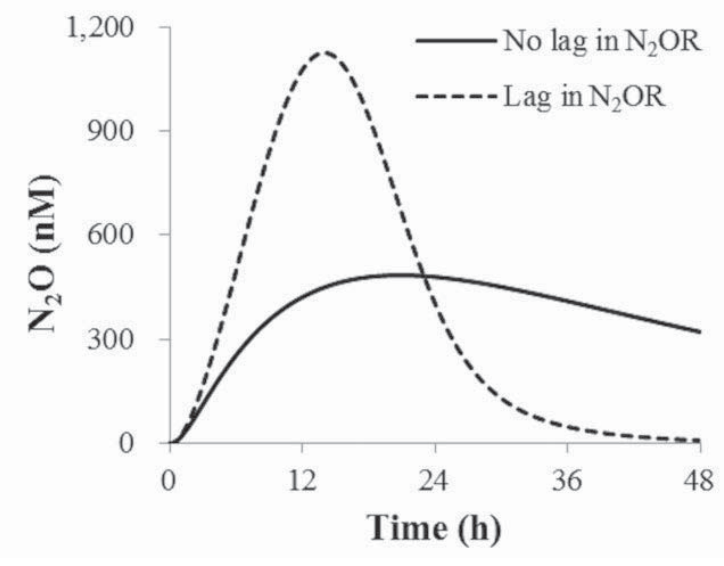

Figure 4.5 $\mid$ Simulations of the $\mathrm{N}_{2} \mathrm{O}$ accumulation in soil gas with the metabolic denitrification model. Simulations were run (1) with concurrent activation of all four denitrification enzymes and (2) with a maximum enzyme synthesis rate for NAR, NIR, and NOR that was 40 times higher than the synthesis rate for $\mathrm{N}_{2} \mathrm{OR}$. 


\section{Delayed synthesis of $\mathrm{N}_{2} \mathrm{OR}$ explains dynamics of $\mathrm{N}_{2} \mathrm{O}$ in agricultural soil following rainfall}

Jianqiu Zheng ${ }^{1}$ and Paul V. Doskey ${ }^{1,2,3 *}$

${ }^{1}$ Atmospheric Sciences Program, Michigan Technological University, Houghton, Michigan 49931, USA, ${ }^{2}$ Department of Civil and Environmental Engineering, Michigan Technological University, Houghton, Michigan 49931, USA, ${ }^{3}$ School of Forest Resources and Environmental Science, Michigan Technological University, Houghton, Michigan 49931, USA. *e-mail: pvdoskey@mtu.edu

\section{Supplementary Information}


Table 4.S1 Biotic and abiotic properties of soil core sections sampled before and 6 and $24 \mathrm{~h}$ after the natural precipitation in 2010 .

\begin{tabular}{cllcccc}
\hline $\begin{array}{c}\text { Sampling } \\
\text { Time }\end{array}$ & $\begin{array}{c}\text { Soil section } \\
(\mathrm{cm})\end{array}$ & WFPS & $\begin{array}{c}\mathrm{NH}_{4}^{+} \\
\left(\mu \mathrm{g} \mathrm{g}^{-1}\right)\end{array}$ & $\begin{array}{c}\mathrm{NO}_{3}^{-} \\
\left(\mu \mathrm{g} \mathrm{g}^{-1}\right)\end{array}$ & $\begin{array}{c}\mathrm{EOC} \\
\left(\mu \mathrm{g} \mathrm{g} \mathrm{g}^{-1}\right)\end{array}$ & $\begin{array}{c}\text { PLFA } \\
\left(\mathrm{nmol} \mathrm{g}^{-1}\right)\end{array}$ \\
\hline Before & $0-5$ & 0.44 & 2.81 & 2.93 & 87.14 & 43.35 \\
& $5-10$ & 0.42 & 2.53 & 2.05 & 63.84 & 22.09 \\
& $10-15$ & 0.36 & 2.42 & 2.61 & 62.56 & 12.49 \\
& $15-25$ & 0.30 & 2.42 & 2.61 & 76.69 & 7.53 \\
$6 \mathrm{~h}$ & $0-5$ & 0.66 & 4.20 & 2.02 & 77.18 & 44.21 \\
& $5-10$ & 0.75 & 3.48 & 1.68 & 67.78 & 23.07 \\
& $10-15$ & 0.55 & 3.33 & 2.17 & 82.65 & 12.38 \\
& $15-25$ & 0.62 & 2.74 & 2.70 & 61.31 & 12.02 \\
& $0-5$ & 0.69 & 4.26 & 2.47 & 81.39 & 56.49 \\
& $5-10$ & 0.64 & 3.63 & 1.44 & 67.91 & 30.82 \\
& $10-15$ & 0.56 & 3.35 & 1.27 & 71.94 & 19.29 \\
& $15-25$ & 0.64 & 2.87 & 2.47 & 104.76 & 15.75 \\
\hline
\end{tabular}


Table 4.S2 Primers used in the subject study ${ }^{1,2,3}$.

\begin{tabular}{cll}
\hline Specification & Primer & Sequence $\left(5^{\prime}\right.$-3’') $^{\prime}$ \\
\hline Copper-containing & nirK876 & ATYGGCGGVCAYGGCGA \\
Nitrite reductase & nirK1040 & GCCTCGATCAGRTTRTGGTT \\
Cytochrome cd1 & nirSF & AACGYSAAGGARACSGG \\
nitrite reductase & nirSR & GASTTCGGRTGSGTCTTSAYGAA \\
nitrous oxide & nosZ1F & WCSYTGTTCMTCGACAGCCAG \\
reductase & nosZ1R & ATGTCGATCARCTGVKCRTTYTC \\
\hline
\end{tabular}




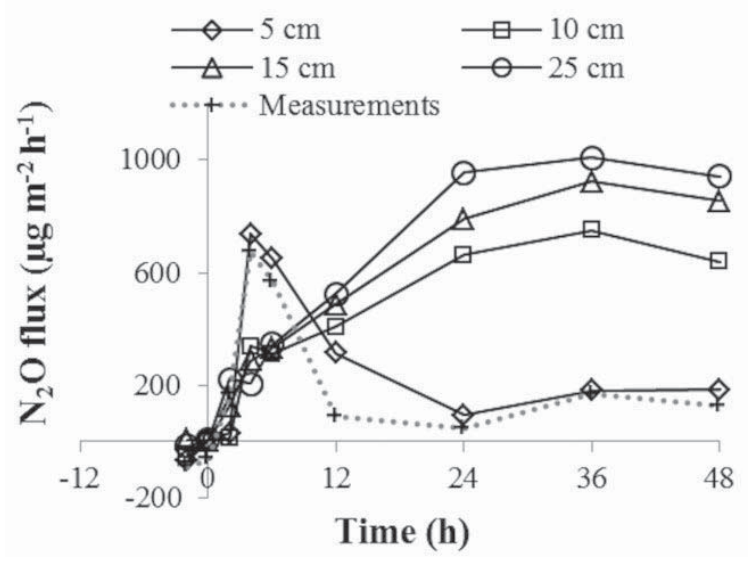

Figure 4.S1 | Diffusive flux from 4 depths in the soil based on Fick's Law.

Effective diffusion coefficient $\left(D_{e} / D_{0}=\theta_{a}^{25} \theta_{r}^{-1.3}\right)$ estimated with Bartelt-Hunt and Smith's soil gas diffusivity model ${ }^{4}$. 


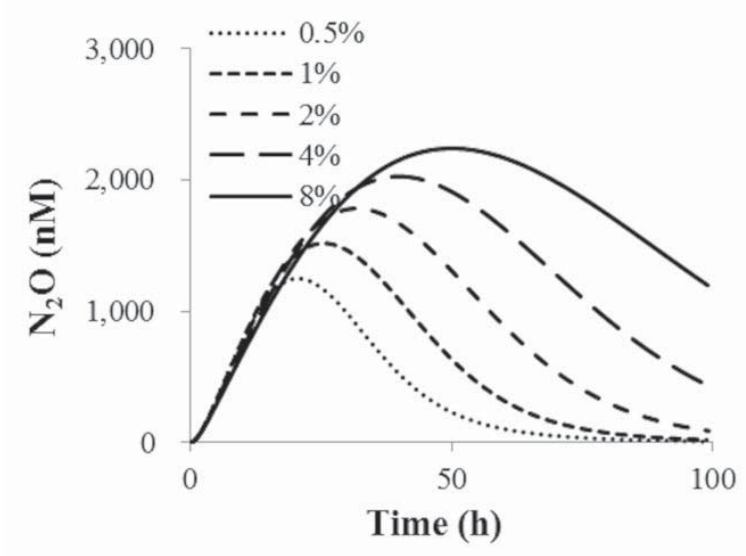

Figure 4.S2 $\mid$ Simulations of the temporal variations of $\mathrm{N}_{2} \mathrm{O}$ concentrations in soil gas. The $\mathrm{N}_{2} \mathrm{O}$ concentrations were estimated with the metabolic denitrification model at constant concentrations of $\mathrm{O}_{2}$. Maximum synthesis rates of NAR, NIR, NOR, and $\mathrm{N}_{2} \mathrm{OR}$ were parameterized according to the incubated soil cores sampled prior to the rainfall simulation experiment at a depth of $0-5 \mathrm{~cm}^{5}$. 


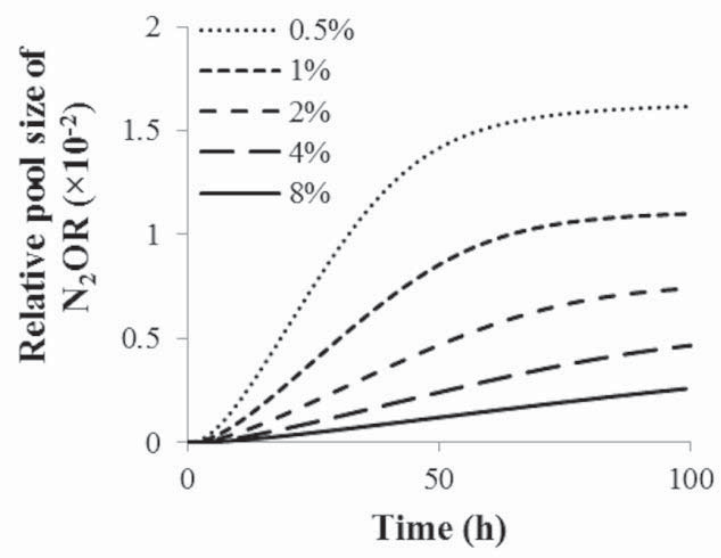

Figure 4.S3 $\mid$ Simulations of temporal variations of the relative pool size of active $\mathrm{N}_{2} \mathrm{OR}$. The relative pool size of active $\mathrm{N}_{2} \mathrm{OR}$ was simulated as a dimensionless factor (from 0-1with 1 representing maximum activity) with the metabolic denitrification model at constant concentrations of $\mathrm{O}_{2}$. 

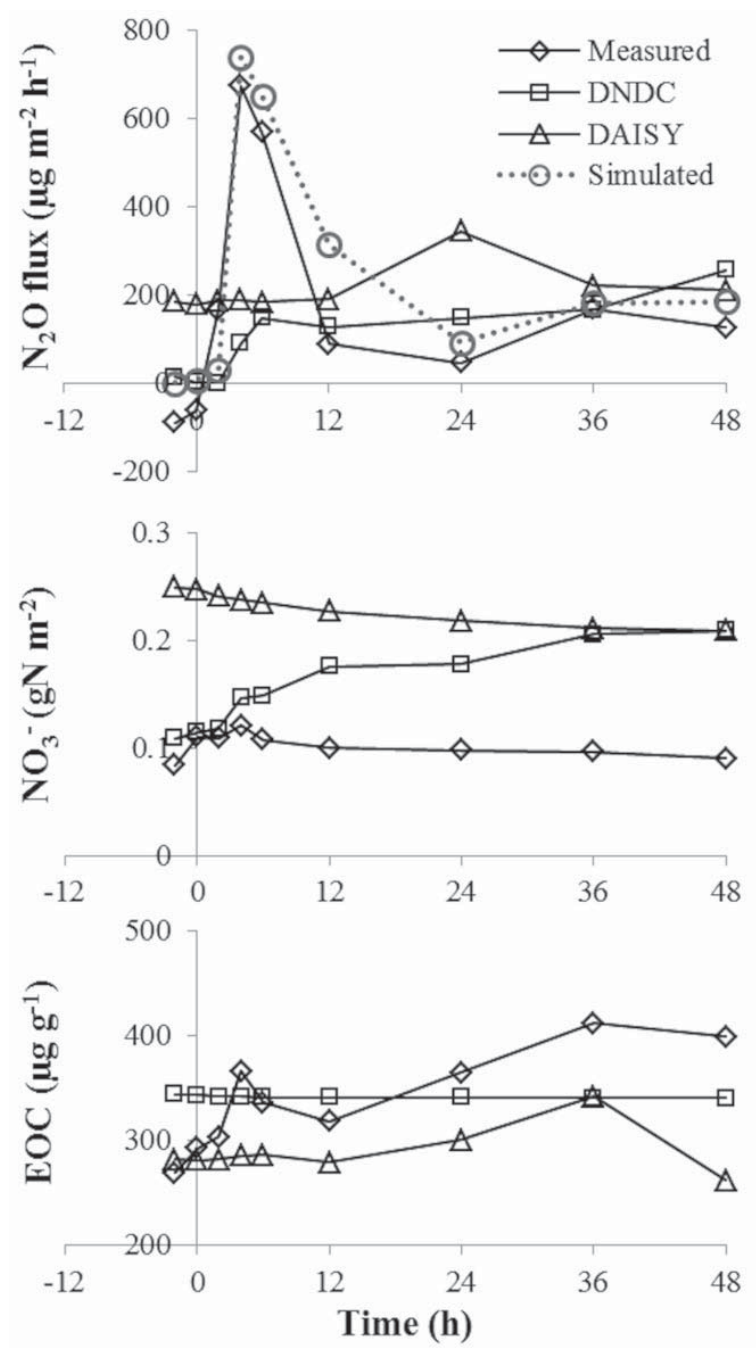

\section{Figure 4.S4 | Comparison of DNDC and DAISY model simulations with} measurements of the temporal variation in surface $\mathrm{N}_{2} \mathrm{O}$ flux and the estimated diffusive flux from $0-5 \mathrm{~cm}$ belowground. Estimates of the temporal variation in soil $\mathrm{NO}_{3}{ }^{-}$and EOC content between 0-25 $\mathrm{cm}$ belowground from DNDC and DAISY are compared with the measurements. 


\section{References}

1. Henry, S., Baudoin, E., Lopez-Gutierrez, J. C., Martin-Laurent, F., Brauman, A. \& Philippot, L. Quantification of denitrifying bacteria in soils by nirK gene targeted real-time PCR. J. Microbiol. Meth. 59, 327-335 (2004).

2. Henry, S., Bru, D., Stres, B., Hallet, S. \& Philippot, L. Quantitative detection of the nosZ gene, encoding nitrous oxide reductase, and comparison of the abundances of $16 \mathrm{~S}$ rRNA, narG, nirK, and nosZ genes in soils. Appl. Environ. Microbiol. 72, 5181-5189 (2006).

3. Throbäck, I. N., Enwall, K., Jarvis, Å. \& Hallin, S. Reassessing PCR primers targeting nirS, nirK and nosZ genes for community surveys of denitrifying bacteria with DGGE. FEMS Microbiol. Ecol. 49, 401-417 (2004).

4. Bartelt-Hunt, S. L. \& Smith, J. A. Measurement of effective air diffusion coefficients for trichloroethene in undisturbed soil cores. J. Contam. Hydrol. 56, 193-208 (2002).

5. Zheng, J. \& Doskey, P. V. Modeling nitrous oxide production and reduction in soil through explicit representation of denitrification enzyme kinetics. Environ. Sci. Technol. submitted (2014). 


\section{Chapter 5 Conclusions and Perspectives}

Denitrification is the primary process for $\mathrm{N}_{2} \mathrm{O}$ production, and it is also only the biological sink to remove $\mathrm{N}_{2} \mathrm{O}$. The complexity of biotic and abiotic interactions on the denitrification process requires better understanding of the microbial kinetics and environmental regulations of denitrification. This work demonstrates that the highly variable $\mathrm{N}_{2} \mathrm{O}$ dynamics is partly due to the unbalanced activities of denitrification enzymes, which are controlled by multiple environmental signals. Constitutive expression of denitrification enzymes independent of substrate induction plays an important role in denitrification process and subsequent $\mathrm{N}_{2} \mathrm{O}: \mathrm{N}_{2}$ product ratio. Nitrous oxide reductase $\mathrm{N}_{2} \mathrm{OR}$ seems to be more fragile comparing to the other three denitrification enzymes, as the its biosynthesis and maintenance of its activity requires restrict environmental conditions. Development of metabolic model on denitrification with explicit representation of denitrification enzyme kinetics is proved to be a powerful tool for simulations of temporal $\mathrm{N}_{2} \mathrm{O}$ accumulations for both the laboratory experiments and field observations. Implementation of such metabolic models into current biogeochemical models is a promising way to accurately simulate the dynamics of surface $\mathrm{N}_{2} \mathrm{O}$ fluxes.

Despite decades of research on $\mathrm{N}_{2} \mathrm{O}$ emissions, few tools are available for mitigations, and one of the key solutions proposed for mitigation is to improve the product stoichiometry of denitrification $\left(\mathrm{N}_{2} \mathrm{O}: \mathrm{N}_{2}\right)$ by focusing on the $\mathrm{N}_{2} \mathrm{O}$-reducing ability of the denitrifiers (Saggar et al., 2013, Thomson et al., 2012). Due to the 
nearly absent field observations on $\mathrm{N}_{2}$ emissions, biogeochemical models are the dominant tool for evaluation on the product ratio of $\mathrm{N}_{2} \mathrm{O}$ : $\mathrm{N}_{2}$, but they are usually associated with large uncertainties due to the inability to capture the emission dynamics from the surface. Thus, new models with more elaborate and legitimate representations of the microbiological basis of denitrification may improve the performance of current models with greater certainty and potentially provide mitigation options. 


\section{Appendix A Weather data file for biogeochemical simulations}

Data for the AmeriFlux Site in Bondville, Illinois is available for evaluation. No-till agriculture has been practiced at the site for more than twenty years, with the rotation of corn (C4) and soybeans (C3) annually since 2000. A National Atmospheric Deposition Program Site near the Bondville AmeriFlux site is maintained by the Illinois State Water Survey, monitoring on-site meteorology and precipitation chemistry.

The climate at Bondville, IL is warm during summer and very cold during winter. The warmest month of the year is July with an average maximum temperature of $29.6^{\circ} \mathrm{C}$, while the coldest month of the year is January with an average minimum temperature of $-9{ }^{\circ} \mathrm{C}$. The annual average precipitation at Bondville is 41.06 Inches. Rainfall in is fairly evenly distributed throughout the year. The wettest month of the year is May with an average rainfall of 4.80 Inches. The field was planted with corn during 2005 and 2007, with soybeans during 2006 and 2008.

The AmeriFlux site is designed to provide a long-term continuous record of the energy balance components for model testing and evaluation. Continuous monitoring of carbon flux, energy balance, and weather conditions was initiated in 1996. The vertical turbulent fluxes of $\mathrm{CO}_{2}$, sensible and latent heat are measured using the eddy covariance method at a height of $10 \mathrm{~m}$ over a no-till maize and soybean rotation ecosystem. The measurement is performed using a RM Young 81000 sonic 
anemometer at $10 \mathrm{~Hz}$. Soil heat flux is measured by The Hukseflux HFP01SC selfcalibrating heat flux sensor at $4 \mathrm{~cm}$ depth. The CNR1 net radiometer by Kipp \& Zonen was used to measure net radiation.

\section{References}

1. Bondville AmeriFlux Site, AmeriFlux US-Bo1(2012) sponsored by NOAA/GEWEX. http://ameriflux.ornl.gov/fullsiteinfo.php?sid=44

2. Coordinated Energy and Water Cycle Observations Project (2012) sponsored by NOAA Climate Program Office (CPO). http://www.eol.ucar.edu/field_projects/ceop

3. National Atmospheric Depostion Program (2012). $\underline{\text { http://nadp.isws.illinois.edu/ }}$

4. Water and Atmospheric Resources Monitoring Program (2012) sponsored by Illinois State Water Survey. http://www.isws.illinois.edu/warm/ 